Portland State University

PDXScholar

\title{
Emerging Technologies and Cities: Assessing the Impacts of New Mobility on Cities
}

\author{
Rebecca Lewis \\ University of Oregon \\ Rebecca Steckler \\ University of Oregon
}

Follow this and additional works at: https://pdxscholar.library.pdx.edu/trec_reports

Part of the Transportation Commons, Urban Studies Commons, and the Urban Studies and Planning Commons

Let us know how access to this document benefits you.

\section{Recommended Citation}

Lewis, Rebecca and Steckler, Rebecca. Emerging Technologies and Cities: Assessing the impacts of new mobility on cities. NITC-RR-1249.Portland, OR: Transportation Research and Education Center (TREC), 2020. https://dx.doi.org/10.15760/trec.245

This Report is brought to you for free and open access. It has been accepted for inclusion in TREC Final Reports by an authorized administrator of PDXScholar. Please contact us if we can make this document more accessible: pdxscholar@pdx.edu. 


\title{
Emerging Technologies and Cities Assessing the Impacts of New Mobility on Cities
}

\author{
Final Report
}

NITC-RR-1249

by

Rebecca Lewis, PhD Rebecca Steckler, AICP

University of Oregon

for

National Institute for Transportation and Communities (NITC)

P.O. Box 751

Portland, OR 97207

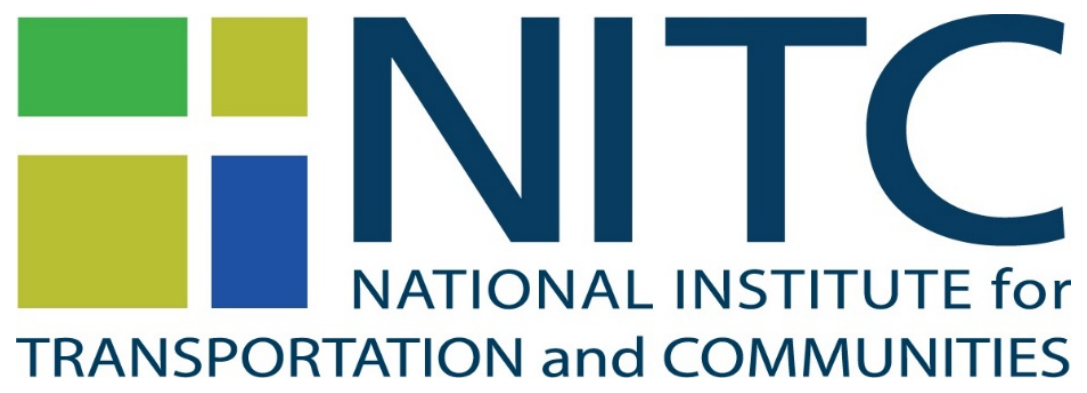

January 2020 


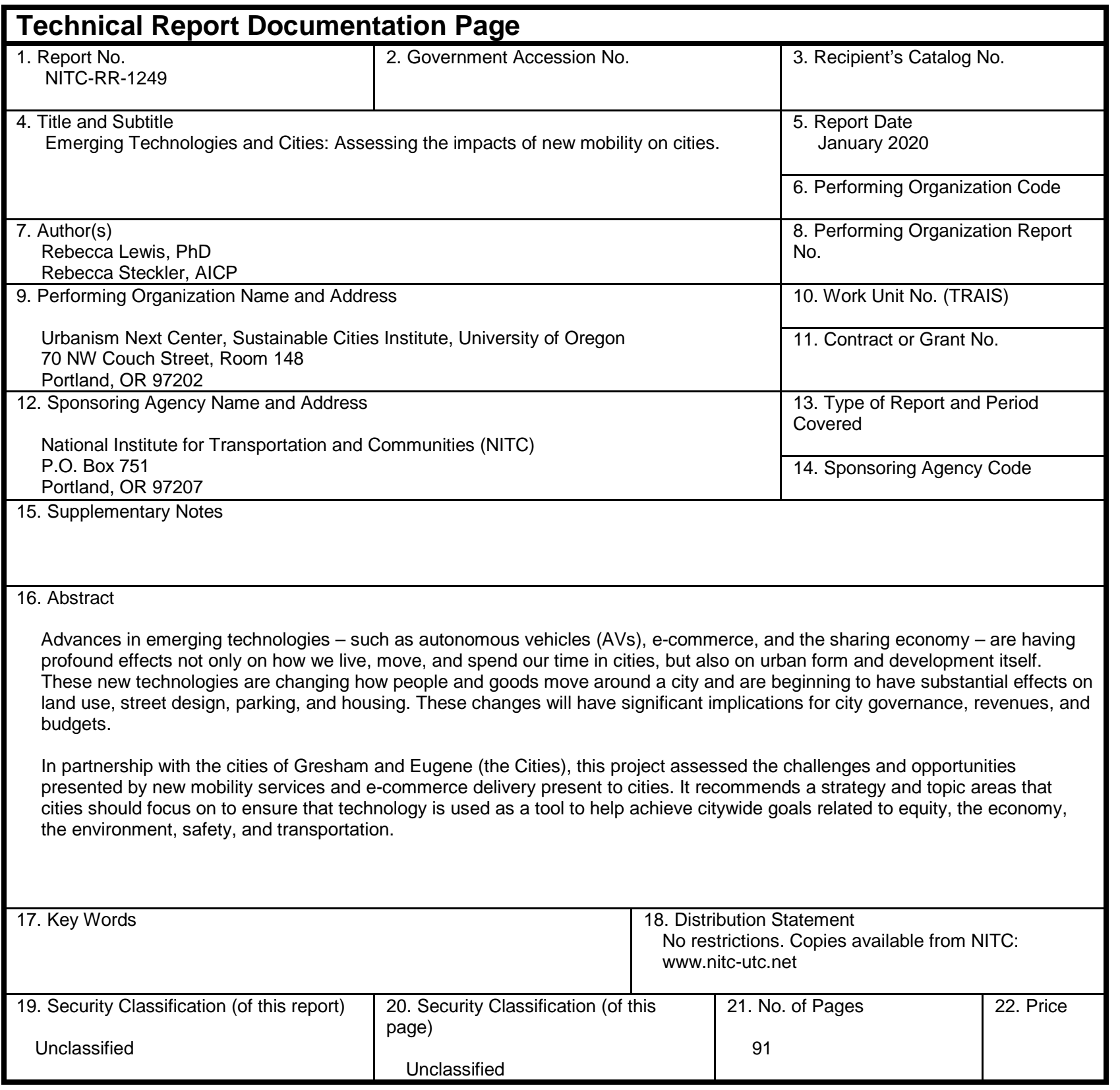




\section{ACKNOWLEDGEMENTS}

The authors would like to acknowledge the partial support from the National Institute for Transportation and Communities (NITC; grant number 1249), a U.S. DOT University Transportation Center, and the National Science Foundation (NSF; Grant number BCS123456). We would also like to thank the City of Gresham for financial and technical support from David Berniker, John Heili, Katherine Kelly, Amanda Lunsford, and Carly Rice. Thank you for the financial and technical support from the City of Eugene and Terri Harding, Chris Henry, Rob Inerfeld, Jeff Petry, Shane Rhodes, Lacey Risdal, Matt Rodrigues, and Larisa Varela. Thanks also to the University of Oregon staff, professors, and the approximately 147 students who studied the two cities. University of Oregon staff and professors who participated in this project include: Megan Banks, Anne Brown, PhD; Benjamin Clark, PhD; Katie Fields; Michael Howard; Rob Ribe, PhD; Marsie Surguine; Josh Skov; and Yizhao Yang, PhD.

\section{DISCLAIMER}

The contents of this report reflect the views of the authors, who are solely responsible for the facts and the accuracy of the material and information presented herein. This document is disseminated under the sponsorship of the U.S. Department of Transportation University Transportation Centers Program, the University of Oregon, City of Gresham, and the City of Eugene in the interest of information exchange. The U.S. Government, City of Gresham, and the City of Eugene assumes no liability for the contents or use thereof. The contents do not necessarily reflect the official views of the U.S. Government, City of Gresham, and the City of Eugene. This report does not constitute a standard, specification, or regulation.

\section{RECOMMENDED CITATION}

Lewis, Rebecca and Steckler, Rebecca. Emerging Technologies and Cities: Assessing the impacts of new mobility on cities. NITC-RR-1249. Portland, OR: Transportation Research and Education Center (TREC), 2019. 


\section{TABLE OF CONTENTS}

EXECUTIVE SUMMARY

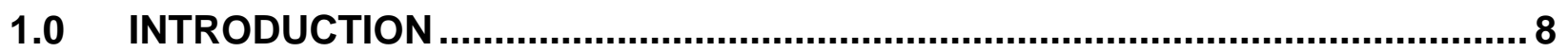

1.1 BACKGROUND AND PURPOSE OF THIS REPORT …............................. 8

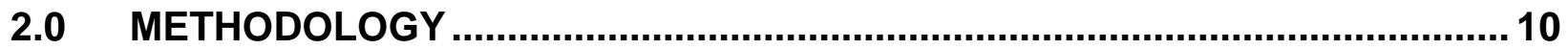

2.1 LITERATURE AND POLICY REVIEW …............................................ 10

2.2 CONTENT ANALYSIS OF CASE STUDY CITY POLICIES, PROGRAMS, AND DEPARTMENT BUDGETS …..................................................................... $10 \quad 2.3$ WORKSHOPS AND CONSULTATIONS WITH CITY STAFF

1

3.0 CHALLENGES AND OPPORTUNITIES OF NEW MOBILITY.......................... 14

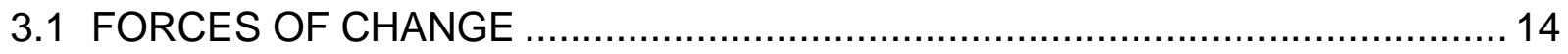

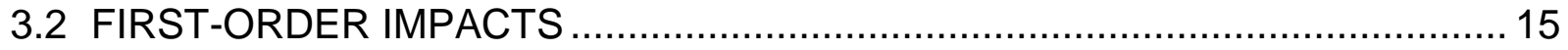

3.2.1 Change in the demand for parking ....................................................... 15

3.2.2 Change in vehicle miles/kilometers traveled........................................... 16

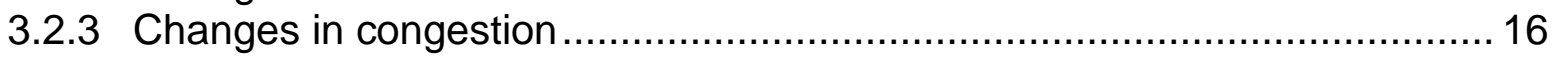

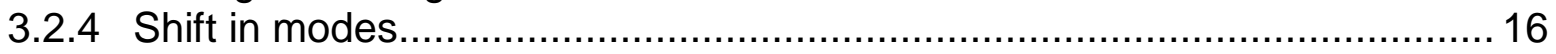

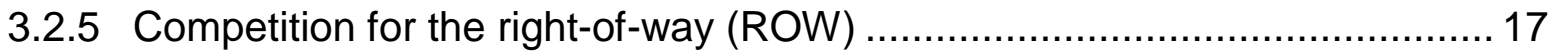

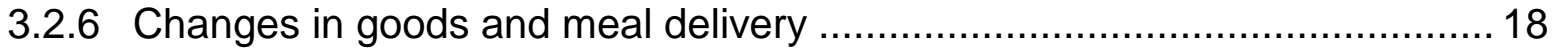

3.2.7 Increased demand for warehousing and distribution space ..................... 19

3.2.8 Reduction in certain types of brick-and-mortar stores ............................. 20

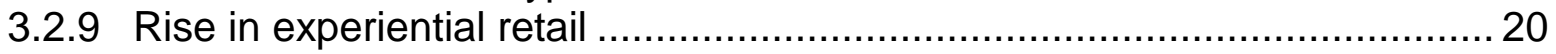

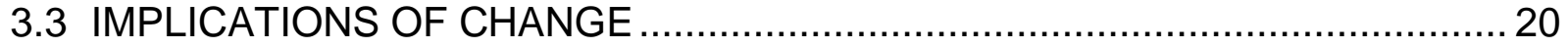

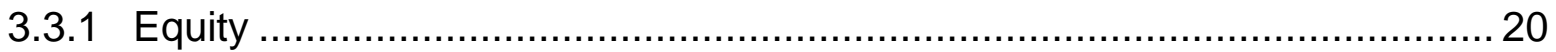

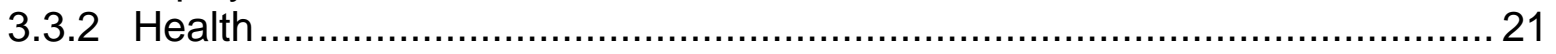

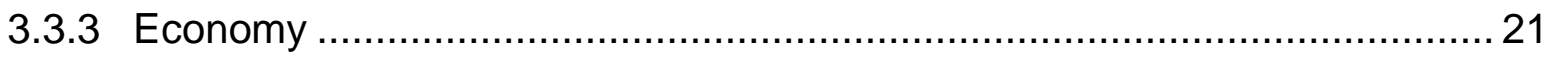

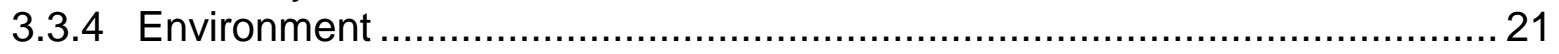

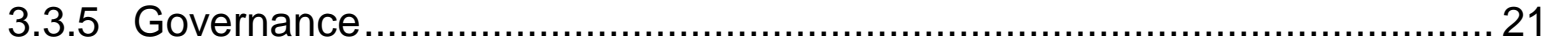

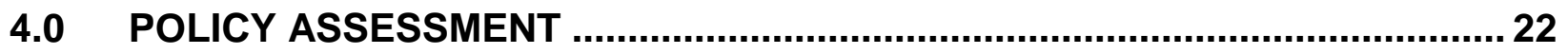

4.1 NATIONAL NEW MOBILITY POLICIES ASSESSMENT ............................... 22

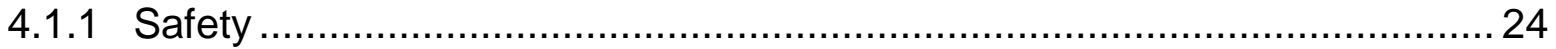

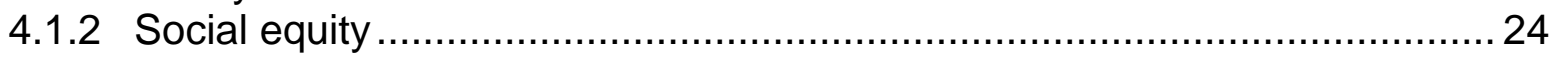

4.1.3 Active transportation (Walk, bike, e-scooter/transit) ................................ 25

4.1.4 Congestion and vehicle miles traveled ................................................ 27

4.1.5 Sustainability and environmental impacts.............................................2 28

4.1.6 Design and management of the right-of-way ......................................... 29

4.1.7 Consider changes in land use and metropolitan footprint............................ 34

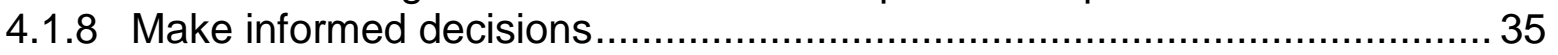

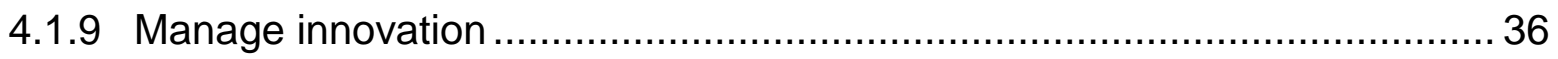

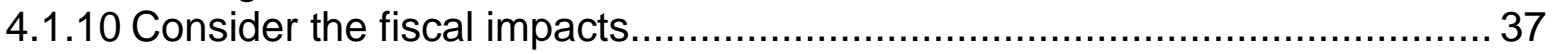

4.2 GRESHAM AND EUGENE POLICY ASSESSMENT FOR NEW MOBILITY...... 39

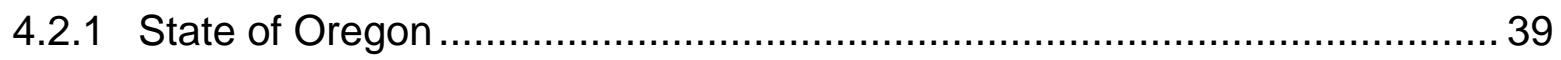




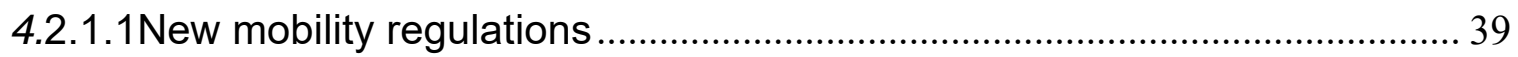

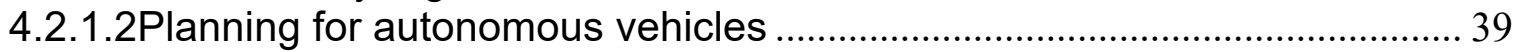

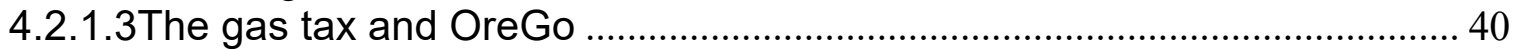

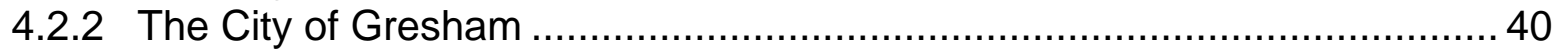

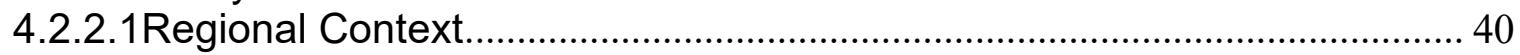

4.2.2.2 .... Policy Scan: Relevant goals, policies, and actions; opportunities, gaps,

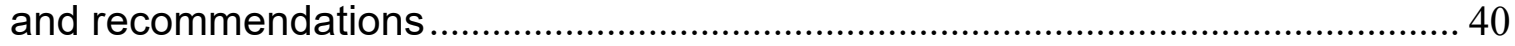

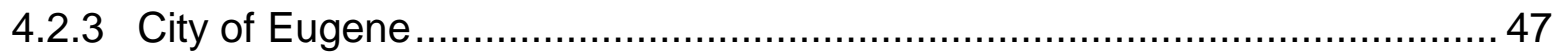

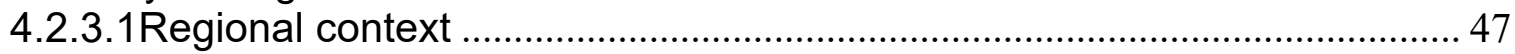

4.2.3.2 Policy scan: relevant goals, policies, and actions; opportunities, gaps, and

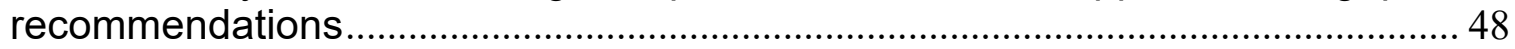

5.0 SUSTAINABLE CITY YEAR PROGRAM CLASS FINDINGS ........................59

5.1 IMPACTS OF AUTONOMOUS VEHICLES ON TRANSPORTATION REVENUES

.

5.2 CAN NEW MOBILITY SERVICES REDUCE RELIANCE ON SINGLEOCCUPANCY VEHICLES? ..................................................................6

5.3 FUTURE-PROOFING COMPREHENSIVE PLANS FROM NEW MOBILITY

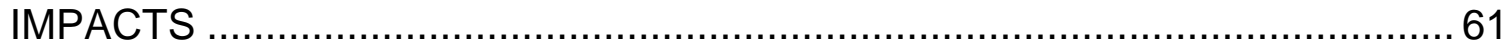

5.4 HOW CAN CITIES PLAN FOR PARKING AND BICYCLE INFRASTRUCTURE IN

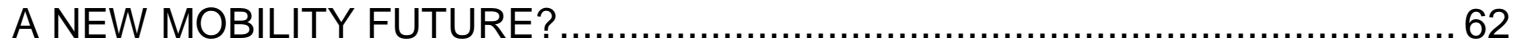

5.5 URBAN DESIGN OPTIONS FOR DOWNTOWN GRESHAM ........................6 64

5.6 POLICY SUGGESTIONS FOR NEW MOBILITY-RELATED TRANSPORTATION

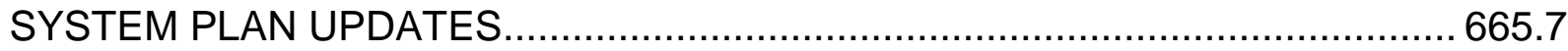

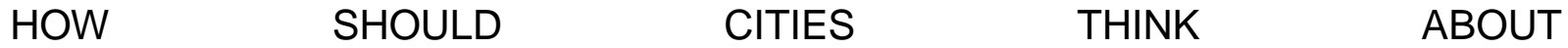

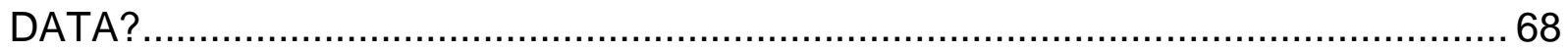

6.0 NEW MOBILITY STRATEGY AND POLICY RECOMMENDATIONS ................71

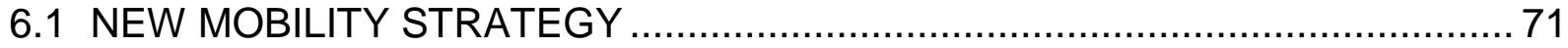

6.1.1 Start with community values and goals ............................................. 71

6.1.2 Coordinate with regional partners................................................... 72

6.1.3 Develop a data privacy, management, and analysis plan ......................... 73

6.1.4 Track new mobility and e-commerce policies, programs, and research in larger cities and regions across the US ......................................................... 74 6.1.5 Inform decision makers and residents about how emerging technologies are impacting cities. 74

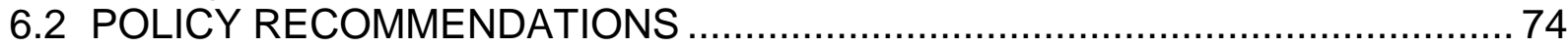

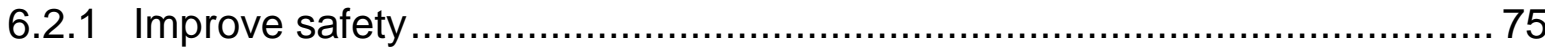

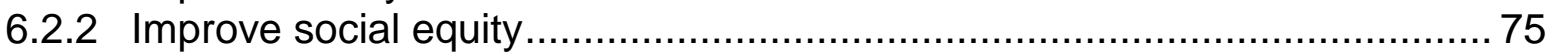

6.2.3 Promote active transportation.......................................................... 76

6.2.4 Decrease greenhouse gas emissions and improve environmental quality .. 77

6.2.5 Reduce vehicle miles traveled and congestion..................................... 78

6.2.6 Adapt right-of-way design and management for new mobility services ....... 78

6.2.7 Consider and manage changes in land use and metropolitan footprint....... 80

6.2.8 Make informed decisions by requiring information ................................. 81

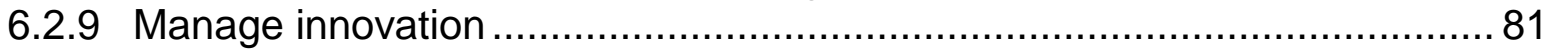

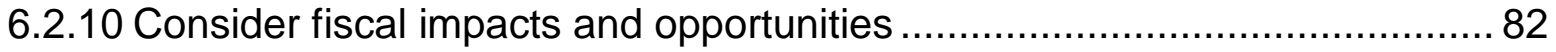

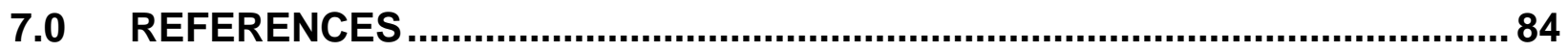




\section{LIST OF TABLES}

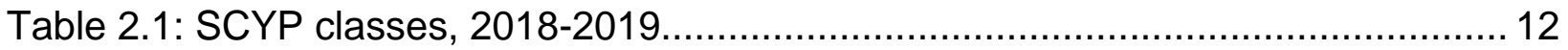

Table 4-1: Sample of new mobility policies and implementing regulations..................... 23

Table 4-2: Prioritization of modes, Portland, OR, and Victoria, BC, 2019 .................... 26

Table 4-3: City of Gresham scan of policies relevant for new mobility .......................... 41

Table 4-4: City of Eugene scan of policies relevant for new mobility...........................5 50

Table 6-1: Prioritization of modes, Portland, OR, and Victoria, BC, 2019 .................... 78

\section{LIST OF FIGURES}

Figure 3-1: Average annual number of parcels received per person in selected countries

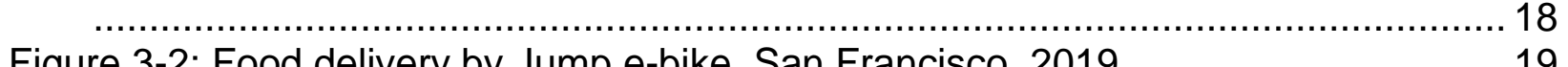

Figure 4-1:. Conceptual street capacity of different modes, NACTO, $2017 \ldots \ldots \ldots \ldots \ldots . . . . .26$

Figure 4-2: Dockless bike and e-scooter parking, City of Santa Monica, 2018 ............. 31

Figure 4-3: Starship terrestrial drone ................................................................... 31 Figure 4-4: Primary functions of the Right-of-Way as defined by the Seattle Department

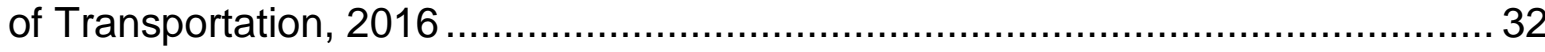

Figure 4-5: Street right-of-way (ROW) zones as designated by SDOT ……............... 33

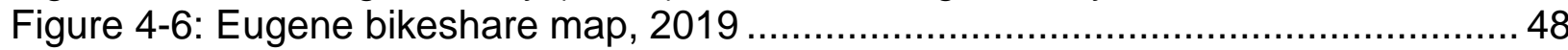

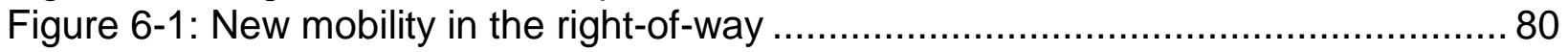




\section{EXECUTIVE SUMMARY}

Digital devices - such as smart phones, tablets, and computers - are significantly changing how people and goods move. Leaders in communities where new mobility services and e-commerce deliveries exist are grappling with how to take advantage of the benefits of these services and mitigate the challenges. Government agencies are just beginning to create strategies and policies to ensure that these new mobility services help communities achieve their goals. These efforts are being led primarily by cities, but transit agencies, coalitions of cities, regional governments, and, increasingly, states are also developing new mobility strategies and policies.

The purpose of this report is to analyze potential impacts and offer recommendations for the cities of Gresham and Eugene, OR, to understand the potential impacts of new mobility technologies - with an emphasis on autonomous vehicles (AVs) - and prepare a policy and programmatic response. While Gresham and Eugene are case studies, it provides mid-sized communities information on how new mobility services could impact their communities and what they can do about it, from broad strategies to specific policy responses. While this work focuses on the various new mobility and goods delivery services that currently exist, the framework that is discussed here is also applicable to emerging technologies that haven't yet been introduced, such as autonomous vehicles (AVs).

The introduction of new mobility services and the growth of e-commerce are rapidly changing transportation systems across the United States and in Oregon. The cities of Gresham and Eugene understand that they need to tackle these issues head-on. The Urbanism Next Center recommends that each city adopt a new mobility strategy that addresses a number of key policy topics. A new mobility strategy should:

- Start with community values and goals.

- Coordinate with regional partners.

- Develop a data privacy, management, and analysis plan.

- Continue to learn from new mobility and e-commerce research, policies, and programs in larger cities and regions across the U.S.

- Inform decision makers and residents about how emerging technologies are impacting cities.

In addition, a new mobility strategy should ensure that cities can:

- Improve safety 
- Improve social equity

- Promote active transportation

- Decrease greenhouse gas emissions and improve environmental quality

- Reduce vehicle miles traveled and congestion

- Adapt right-of-way design and management for new mobility services

- Consider and manage changes in land use and metropolitan footprint

- Make informed decisions by requiring information

- Manage innovation

- Consider fiscal impacts and opportunities 


\subsection{INTRODUCTION}

\subsection{BACKGROUND AND PURPOSE OF THIS REPORT}

In 1994, Jeff Bezos left his Wall Street firm to move to Seattle and eventually create Amazon. In the mid-1990s it was hard to imagine how Amazon would eventually grow into the behemoth it is today, capturing one-third of all e-commerce sales (Lipsman, 2019). According to the Pew Research Center, eight in 10 Americans made an online purchase in 2015 (Smith and Anderson, 2016) and according to José Holguin-Veras, a researcher at Rensselaer Polytechnic Institute, freight deliveries per person have doubled over the past decade and could double again by 2023 (Humes, 2018). The resulting deliveries from these purchases are increasing traffic and commercial parking as more and more goods are delivered to more homes and businesses.

Similarly, it was hard to predict when Uber launched its app in 2009 that connected drivers with people who needed a ride, it would usher in mobility as a service that now includes e-scooters, dockless bikes and e-bikes. It also showed the potential of a myriad of ways that people can move without using a personally owned vehicle. The introduction of new mobility services in other cities has felt more like invasions, such as when e-scooters were introduced in Santa Monica and San Francisco (Brinklow, 2018; Cabanatuan, 2018; Men, 2018). With 38 million rides in the first year (NACTO, 2019a), it is perhaps unsurprising that city officials feel overwhelmed.

What these emerging technologies make clear is that our digital devices are significantly changing how people and goods move. Leaders in communities where new mobility services and e-commerce deliveries exist are grappling with how to take advantage of the benefits of these services and mitigate the challenges. Government agencies are just beginning to create strategies and regulations to ensure that these new mobility services help communities achieve their goals. These efforts are being led primarily by cities, but transit agencies, coalitions of cities, regional governments, and, increasingly, states are also developing new mobility strategies and policies.

The purpose of this report is to help the cities of Gresham and Eugene, OR, understand the potential impacts of new mobility technologies - with an emphasis on autonomous vehicles (AVs) - and prepare a policy and programmatic response. While Gresham and Eugene are case studies, it provides communities of all sizes (with an emphasis on midsized cities) information on how new mobility services could impact their communities and what they can do about it, from broad strategies to specific policy responses. While this work focuses on the various new mobility and goods delivery services that currently exist, the framework that is discussed here is also applicable to emerging technologies that haven't yet been introduced, such as autonomous vehicles (AVs).

What was once purely science fiction is starting to materialize on streets across the country. Being prepared for these changes is what makes the difference between a community achieving its goals or being plagued with negative impacts. In order to help the cities of Gresham and Eugene navigate the challenges and opportunities of new 
mobility, the Urbanism Next Center professional research staff partnered with the Sustainable City Year Program (SCYP) to leverage the resources of the University of Oregon.

This report includes a literature review of the drivers of change and first-order impacts of new mobility and e-commerce. It then reviews the policy approaches of communities across the country before an analysis of Gresham and Eugene's adopted policies that have implications for new mobility services. The policy analysis also includes a discussion of opportunities to amend existing policies as well as gaps in existing policies that could be addressed. We then describe the key questions, findings, and recommendations from the eight SCYP classes that participated in this project. Finally, we bring it all together to recommend a new mobility strategy and discuss key policy issues that could be addressed in the strategy. 


\subsection{METHODOLOGY}

\subsection{LITERATURE AND POLICY REVIEW}

The Urbanism Next team began the project by completing a literature review of the evidence to date on the current status of development and deployment of new mobility and $A V s$ (such as timing, infrastructure changes required, fuel source (gas vs. electric, etc.)), and the range of possible impacts that new mobility technologies could have on cities relative to mode demand, travel patterns, land valuation, development patterns, building design, and housing location choices. This literature review was conducted in tandem with a National Science Foundation grant.

In addition to examining the academic literature to date, the Urbanism Next team evaluated the current policy guidance from national organizations and case studies of cities across the United States. The team compiled information from existing playbooks, policies, and strategies for new mobility and emerging transportation technologies. Some cities, such as Seattle, WA, Los Angeles, CA, and Austin, TX, have created or adopted new mobility policies or strategies. Other cities, such as Atlanta, GA, and St. Louis, MO, are incorporating elements of new mobility topics into current planning documents or regulations. Note that the authors included all publicly available new mobility strategies we were aware of as of March 2019.

\subsection{CONTENT ANALYSIS OF CASE STUDY CITY POLICIES, PROGRAMS, AND DEPARTMENT BUDGETS}

The Urbanism Next team examined comprehensive plans, strategic plans, and transportation systems plans for the cities of Eugene and Gresham to evaluate goals and policy priorities. This review informs how new mobility will affect policies, plans and budgets within cities.

We examined the City of Gresham's long-range policies for transportation and land use for goals, objectives, strategies, and action items that should be considered when developing new mobility policies. Urbanism Next researchers conducted a preliminary scan of Gresham's plans, including the Transportation System Plan (2014), the Active Transportation Plan (2018), and the Comprehensive Plan.

In Eugene, we examined transportation policies, land use policies, environmental policies and economic policies for goals, policies, guidelines, and action items that shape ways transportation services serve and interact with the city. The policies and plans include: Eugene 2035 Transportation System Plan (2017); Eugene Vision Zero Action Plan (2019); MoveEUG: Eugene's Active Transportation Strategy (2017-2021); Envision Eugene Comprehensive Plan (2017); DRAFT Community Design Handbook (2017); A Community Climate and Energy Action Plan for Eugene (2010); and Regional Prosperity Economic Development Plan: Eugene, 
Springfield, Lane County (2010).

To summarize the literature review, policy review, and content analysis of city plans and policies, the Urbanism Next team created a report called Navigating New Mobility Report (September 2019). This report is an overview of how new mobility services (including shared bikes, scooters, ride and car share, microtransit, and autonomous vehicles) for both passenger and goods delivery may impact communities. It includes a literature review on the first-order impacts of new mobility services and introduces the topics communities should consider when developing new mobility policies, from broad strategies to permitting. While this work focuses on the various new mobility and goods delivery services that currently exist, the framework that is discussed here is also applicable to emerging technologies that haven't yet been introduced, such as autonomous vehicles (AVs). It also includes a new mobility policy scan of Gresham and Eugene policies that have implications for new mobility services. Policies scanned included the Eugene and Gresham comprehensive plans, transportation system plans, climate action plans (if available), and economic development plans, and highlights potential new mobility policy opportunity and gaps based on the topics identified in the Navigating New Mobility Report. These topics are:

o Improve safety

o Improve social equity

o Promote active transportation

- Decrease greenhouse gas emissions and improve air quality

o Reduce congestion and vehicle miles traveled

o Adapt right-of-way design and management for new mobility services

o Consider and manage changes in land use and metropolitan footprint

o Make informed decisions by requiring information

o Manage innovation

o Consider fiscal impacts

\subsection{WORKSHOPS AND CONSULTATIONS WITH CITY STAFF}

The University of Oregon worked directly with staff from the cities of Gresham and Eugene to revise and refine presentation of information in the project reports throughout the course of this project. In addition, Urbanism Next conducted three workshops with city staff:

- Emerging Technology Workshop (Eugene, Monday, September 24, 2018). Thirty-seven people from the City of Gresham, City of Eugene, City of Springfield, Lane Transit District, Oregon Department of Transportation, and other organizations heard presentations from the University of Oregon about the drivers of change and multilevel impacts and then brainstormed potential implications for the City of Eugene. 
- Navigating New Mobility Draft Recommendations Workshop (Eugene, Friday, February 15, 2019). Nineteen people from the City of Gresham, City of Eugene, and the University of Oregon reviewed and discussed the policy analysis and draft conclusions in the Navigating New Mobility Report.

- Draft Project Conclusions and Recommendations Workshop (Gresham, August 7, 2019). This workshop focused on the findings from all of the SCYP class reports and the Navigating New Mobility Report to refine the conclusions and recommendations that are in Chapter 6 of this report.

The Urbanism Next Center incorporated the feedback from these workshops and other informal consultations into the final reports.

\subsection{SCYP CLASSES}

The bulk of the research for this project occurred with University of Oregon classes paired with the Sustainable City Year program (SCYP). The following table summarizes the course, topics, and products. The University of Oregon completed eight SCYP classes with participation by 147 students.

Table 2.1: SCYP classes, 2018-2019

\begin{tabular}{|c|c|c|c|c|}
\hline Course & Instructor & Topics & Methods & Products \\
\hline $\begin{array}{l}\text { PPPM 629: } \\
\text { Public Budget } \\
\text { Administration } \\
\text { (Fall 2018) }\end{array}$ & $\begin{array}{l}\text { Rebecca } \\
\text { Lewis }\end{array}$ & $\begin{array}{l}\text { Impact of new mobility } \\
\text { on transportation } \\
\text { revenues and } \\
\text { recommendations for } \\
\text { new revenue sources to } \\
\text { fill the gap. }\end{array}$ & $\begin{array}{l}\text { Budget analysis; } \\
\text { spreadsheet } \\
\text { revenue analysis }\end{array}$ & 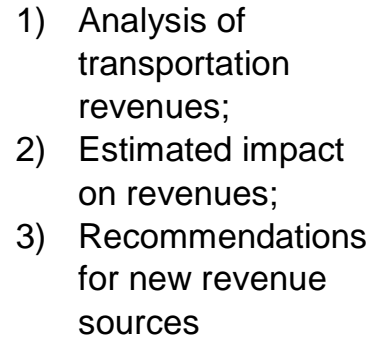 \\
\hline $\begin{array}{l}\text { Management } \\
641 \text { : Industrial } \\
\text { Ecology } \\
\text { (Fall 2018) }\end{array}$ & $\begin{array}{l}\text { Joshua } \\
\text { Skov }\end{array}$ & $\begin{array}{l}\text { What new lifestyles and } \\
\text { opportunities open up for } \\
\text { individuals and } \\
\text { households when a } \\
\text { community begins to } \\
\text { realize the new } \\
\text { mobility? }\end{array}$ & $\begin{array}{l}\text { Household } \\
\text { scenario analysis; } \\
\text { cost accounting }\end{array}$ & $\begin{array}{l}\text { 1) Analysis of costs of } \\
\text { transportation under } \\
\text { household } \\
\text { scenarios; } \\
\text { 2) Analysis of health, } \\
\text { environmental and } \\
\text { time benefits }\end{array}$ \\
\hline $\begin{array}{l}\text { PPPM 610: } \\
\text { Growth } \\
\text { Management } \\
\text { (Winter 2019) }\end{array}$ & $\begin{array}{l}\text { Rebecca } \\
\text { Lewis }\end{array}$ & $\begin{array}{l}\text { Are comprehensive } \\
\text { plans future-proof for the } \\
\text { impacts of e-commerce } \\
\text { and autonomous } \\
\text { vehicles? What policies } \\
\text { should cities adopt to } \\
\text { prepare for the impacts } \\
\text { of e-commerce and } \\
\text { autonomous vehicles? }\end{array}$ & $\begin{array}{l}\text { Case studies; } \\
\text { content analysis; } \\
\text { policy analysis } \\
\text { and } \\
\text { recommendations }\end{array}$ & $\begin{array}{l}\text { 1) } \begin{array}{l}\text { Analysis of existing } \\
\text { comprehensive } \\
\text { plans; }\end{array} \\
\text { 2) Case studies of } \\
\text { innovative policy } \\
\text { responses; } \\
\text { 3) } \\
\text { Recommendations } \\
\text { to futureproof } \\
\text { comprehensive } \\
\text { plans }\end{array}$ \\
\hline
\end{tabular}




\begin{tabular}{|c|c|c|c|c|}
\hline Course & Instructor & Topics & Methods & Products \\
\hline $\begin{array}{l}\text { PPPM 4/510: } \\
\text { Transportation } \\
\text { Planning } \\
\text { (Winter 2019) }\end{array}$ & $\begin{array}{l}\text { Anne } \\
\text { Brown }\end{array}$ & $\begin{array}{l}\text { What are the current } \\
\text { parking and } \\
\text { micromobility policies } \\
\text { within cities? What are } \\
\text { current usage patterns? } \\
\text { What policies should } \\
\text { cities adopt to address } \\
\text { new mobility? }\end{array}$ & $\begin{array}{l}\text { Data analysis; } \\
\text { policy analysis; } \\
\text { case studies }\end{array}$ & $\begin{array}{l}\text { 1) Data analysis on } \\
\text { current parking and } \\
\text { micromobility usage } \\
\text { and infrastructure; } \\
\text { 2) Policy analysis of } \\
\text { existing policies; } \\
\text { 3) Recommendations } \\
\text { for new policy } \\
\text { approaches }\end{array}$ \\
\hline $\begin{array}{l}\text { PPPM: 633: } \\
\text { Public } \\
\text { Management } \\
\text { (Spring 2019) }\end{array}$ & Ben Clark & $\begin{array}{l}\text { How should cities } \\
\text { develop regulations and } \\
\text { requirements for data } \\
\text { from transportation } \\
\text { service providers as well } \\
\text { as an open data for } \\
\text { public consumption? }\end{array}$ & $\begin{array}{l}\text { Case studies; } \\
\text { policy analysis; } \\
\text { interviews }\end{array}$ & $\begin{array}{l}\text { 1) } \begin{array}{l}\text { Case studies of } \\
\text { innovative policy } \\
\text { responses; }\end{array} \\
\text { 2) Policy analysis of } \\
\text { other jurisdictions } \\
\text { and Gresham and } \\
\text { Eugene policies } \\
\text { 3) Interviews of key } \\
\text { staff }\end{array}$ \\
\hline $\begin{array}{l}\text { PPPM 610: } \\
\text { Land use } \\
\text { Planning } \\
\text { (Spring 2019) }\end{array}$ & $\begin{array}{l}\text { Yizhao } \\
\text { Yang }\end{array}$ & $\begin{array}{l}\text { What can the City of } \\
\text { Eugene learn from other } \\
\text { case study cities how to } \\
\text { make downtown more } \\
\text { accessible to non- } \\
\text { automobile means? } \\
\text { Focus on parking } \\
\text { management, } \\
\text { sustainable } \\
\text { transportation, and } \\
\text { transportation demand } \\
\text { management. }\end{array}$ & $\begin{array}{l}\text { Case studies; } \\
\text { policy analysis }\end{array}$ & $\begin{array}{l}\text { 1) } \begin{array}{l}\text { Case studies of } \\
\text { other cities }\end{array} \\
\text { 2) Recommendations } \\
\text { for new policy } \\
\text { approaches }\end{array}$ \\
\hline $\begin{array}{l}\text { LA 4/589: } \\
\text { Future of } \\
\text { Urban Design } \\
\text { and Planning, } \\
\text { Advanced } \\
\text { Design Studio } \\
\text { (Spring 2019) }\end{array}$ & Rob Ribe & $\begin{array}{l}\text { Students explored the } \\
\text { redesign of several } \\
\text { streets and the old } \\
\text { downtown core of } \\
\text { historic downtown } \\
\text { Gresham in } \\
\text { consideration of } \\
\text { anticipated shifts in } \\
\text { urban transportation, } \\
\text { including ridesharing, } \\
\text { micromobility, and } \\
\text { autonomous driving, as } \\
\text { well as the probable } \\
\text { reduced demand for } \\
\text { parking and the } \\
\text { expectation of the } \\
\text { downtown becoming } \\
\text { more densely populated } \\
\text { with residents over time. }\end{array}$ & Case studies & $\begin{array}{ll}\text { 1) } & \text { Case studies } \\
\text { 2) Urban design } \\
\text { recommendations }\end{array}$ \\
\hline
\end{tabular}

Source: Urbanism Next Center and Sustainable City Year Program, 2018-2019. 


\subsection{CHALLENGES AND OPPORTUNITIES OF NEW MOBILITY}

Cities across the country are grappling to understand the potential impacts of emerging technologies so that they can develop appropriate policies and programs to mitigate challenges and take advantage of opportunities that these technologies present. The Urbanism Next Center focuses on the forces of change from emerging technologies, specifically, autonomous vehicles, e-commerce, and the sharing economy. This chapter summarizes recently completed research on these topics in the Multilevel Impacts of Emerging Technologies on City Form and Development completed in October 2019.

\subsection{FORCES OF CHANGE}

Emerging technologies are changing how people travel and buy food and goods. Urbanism Next thinks about these disruptive technological forces as:

- The introduction of new mobility technology and mobility as a service. Emerging technologies (such as the smart phone and apps) have greatly expanded the ability for people to rent vehicles (such as bikes, scooters, and cars) or get a ride in a car owned and driven by someone else. The proliferation of these services makes it possible for an app to show multiple transportation options and list the trip length, approximate time, cost, and other information. Whim and UbiGo are two companies operating in select European cities. Most apps, like TriMet's Trip Planner and Vermont's Go! Vermont, currently only allow for planning a trip (Theen, 2019), though several states (Vermont) and regions (Denver, Los Angeles, and others) are working with service providers to offer payment options as well.

- The growth of e-commerce and the related rise in goods delivery. Not only are new technologies changing how people move, it is also changing how, and how often, goods and food are delivered. According to the U.S. Census Bureau, the percentage of e-commerce of total retail sales increased from approximately $4 \%$ in 2009 to $10.2 \%$ in the first quarter of 2019 . While package delivery is increasing, it is not known what impact these deliveries are having on the transportation system. Along with package delivery, urban delivery services (sometimes also called courier network services) connect contract couriers with companies such as restaurants and grocery stores to make deliveries to customers (Shaheen et al., 2015).

- The anticipated introduction of autonomous vehicles (AVs). Unlike new mobility services and e-commerce and urban goods delivery, AV transportation is still primarily in the testing phase and only very limited commercial service is available in Las Vegas and the suburbs of Phoenix, AZ (Korosec, 2019). It remains to be seen if AVs operate as a service (like Uber or Lyft) or if people will purchase their own vehicles. Regardless of who owns the vehicles, AVs have the 
potential to dramatically change the transportation landscape. On one hand, it could dramatically increase transportation options for people who cannot or choose not to drive themselves (such as those with disabilities) (Litman, 2018). It could also revolutionize how people get around, either in single-occupancy vehicles (Fehr \& Peers, 2018a) or in shared vehicles like microtransit (MaRS, 2016). AVs have the potential to be a catalyst for e-commerce and local delivery by decreasing the cost to ship and deliver goods and food.

\subsection{THE INTRODUCTION OF NEW MOBILITY AND E-COMMERCE}

While the ability to order goods online has been around since the mid-1990s, it has increased from less than $1 \%$ to over $11 \%$ (adjusted) of all retail sales in between 2000 and the $3^{\text {rd }}$ quarter of 2019 (US Census Bureau, 2019). The availability of online shopping is limited primarily by the availability of personal computers primarily, and a lesser extent smartphones and other digital devices, as well as the availability of credit cards or other sources of online payment.

On the other hand, availability of new mobility services is restricted to where these services are introduced. While European countries were experimenting with bikeshare systems since the 1960s, the first bikeshare system was introduced in the US - in Washington, D.C. - in 2008 (Goodyear, No Date). Since the launch of its first service in San Francisco in 2009, Uber now is in 263 cities (Uber, No date). The explosion of escooters first introduced in Santa Monica, CA in 2018 with over 38 million US rides in 2018 alone, speaks to the latent demand for micromobility (NACTO, 2019a). Service providers generally have introduced these services in the largest U.S. markets.

While multiple companies are testing AVs, it remains to be seen when these services will be available in many or most communities. AVs in dedicated lanes are already available, and several community are working with companies on pilot projects with lowspeed shuttles that operate on a fixed route. It has proven to be much more challenging to operate AVs in mixed traffic for on-demand routes. Waymo is perhaps the farthest along on testing on-demand services and has rolled out limited commercial services in the Phoenix, AZ region (Korosec, 2019). It is truly hard to predict when AVs will be readily available, from Elon Musk's boast that one million robotaxi's will be on the road by 2020 (Kolodny, 2019) to 2030 or beyond (Gerdes, 2018).

\subsection{FIRST-ORDER IMPACTS}

The first-order impacts in this section describe how the forces of change described above may impact the form and function of cities.

\subsubsection{Change in the demand for parking}

UCLA Professor Donald Shoup and many other researchers have documented the abundance of free parking and many of the negative externalities associated with it (Shoup, 2011; Shoup, 2018; Peters, 2018). Transportation network companies (TNCs) 
are impacting parking demand, especially in dense downtown areas and neighborhoods with bars, restaurants, and other nightlife (Morris, 2018; Steele, 2018; Zipkin, 2017). One of the most common reasons people cite for using TNCs is because of the cost or difficulty of parking (Clewlow and Mishra, 2017). One study of four airports found that the introduction of TNCs at the airports resulted in an annualized declining parking rate of 3-7\% per year (Henao et al., 2018). AVs could dramatically decrease the demand for parking by $62 \%$ to $87 \%$ of what we have today (Nourinejad, Bahrami, and Roorda, 2018).

\subsubsection{Change in vehicle miles/kilometers traveled}

Researchers are documenting the many ways that TNCs are increasing, and AVs could increase, total vehicle miles/kilometers traveled. Some TNC riders surveyed by UC Davis researchers indicated that they made more trips because of TNCs (Clewlow and Mishra, 2017). This could be in part because of latent demand that expands mobility for underserved populations (A. Brown, 2018). Studies of the potential impacts of AVs also suggest that travel could increase by $3 \%$ to $27 \%$ due to a variety of factors such as increased demand from people with disabilities, elderly, etc., and people traveling farther because it is more comfortable (Childress, Nichols, Charlton, and Coe, 2015; Correia, Milakis, van Arem, and Hoogendoorn, 2016). In addition, both TNCs and AVs travel "empty" on roads between passengers or drop-off of goods, generating additional VMT (Fagnant and Kockelman, 2014a; Balding et al., 2019; Fagnant and Kockelman, 2014a).

\subsubsection{Changes in congestion}

New mobility services may impact congestion in different ways. Recent research suggests that TNCs are increasing VMT and congestion (Gehrke, Felix and Reardon, 2018; Schaller, n.d.; SFCTA, 2017). Even Uber and Lyft admit they are adding to VMT (Balding et al., 2019). Micromobility services such as bikeshare and e-scooters may decrease congestion if they support transit and people choose to travel not using a vehicle. It remains to be seen if AVs' ability to platoon (drive close together) (Talebpour and Mahmassani, 2016) will make up for the possibility that demand could increase dramatically, as some researchers suspect (World Economic Forum, 2018; Fagnant and Kockelman, 2014).

\subsubsection{Shift in modes}

The introduction of TNCs is changing the transportation landscape by changing how people travel (Graehler Jr., Mucci and Erhardt, 2019; Manville, Taylor and Blumenberg, 2018). The study by Graehler, Mucci, and Erhardt found that bikeshare is associated with an increase in heavy rail and light rail ridership, $6.9 \%$ and $4.2 \%$ respectively, and a $1.8 \%$ decrease in bus ridership. The introduction of TNCs decreases all transit use, $1.3 \%$ for heavy rail and $1.7 \%$ for bus ridership. "In a market like San Francisco, where Uber started operations in 2010, the model implies that we would expect a $12.7 \%$ decrease in bus ridership, all else being equal . . . the results suggests that SFMTA 
would need to increase bus service by slightly more than $25 \%$ in order to offset the loss of bus ridership to TNCs." (Graehler Jr. et al., 2019, p 14).

A survey conducted by Clewlow and Mishra in 2017 found that TNCs are replacing walk, bike and transit trips, or resulting in trips that would not have been taken at all. In Boston, Metropolitan Area Planning Council (MAPC) researchers found that when TNC riders are asked how they otherwise would have traveled, $42 \%$ of people surveyed said they would have taken public transit and $12 \%$ said they would have biked or walked (Gehrke, Felix, and Reardon, 2018).

AVs may reduce the friction of travel by decreasing cost and ease of travel, allowing people to do other more productive or valuable activities than driving. Many researchers anticipate that this could result in a mode shift from active transportation and personally owned vehicles to AVs (LaMondia, Fagnant, Qu, Barrett and Kockelman, 2016;

Childress et al., 2015; Davidson and Spinoulas, 2015; Truong, De Gruyter, Currie and Delbosc, 2017).

\subsubsection{Competition for the right-of-way (ROW)}

The introduction of new mobility services and e-commerce has increased demand for pick-up and drop-off of people and goods. Two studies in San Francisco and Cincinnati by Fehr \& Peers for Uber found that the demand for pick-up and drop-off exceeded the supply, resulting in conflicts with pedestrians, cyclists, transit, and other users (Fehr \& Peers, 2018b, 2019). The National Association of City Transportation Officials (NACTO) reported that the introduction of e-scooters in 2018 resulted in over 38.5 million rides (NACTO, 2019b). All of those e-scooters are parked on the sidewalk and sometimes make passage difficult for pedestrians.

Not only are micromobility vehicles and TNCs increasing the demand for the ROW and especially the curb, but e-commerce and goods delivery services are also increasing the demand for pick-up and drop-off space. As mentioned earlier, José Holguin-Veras, a researcher at the Rensselaer Polytechnic Institute, estimates that freight deliveries per person have doubled over the past decade and will double again by 2023 (Humes, 2018). According to Pitney Bowes, the average person in the United States receives 21 packages per year, as shown in Figure 3-1. 
Figure 3-1: Average annual number of parcels received per person in selected countries

\section{Online Shopping: Where The Parcels Are Piling Up}

Average annual number of parcels received per person in selected countries
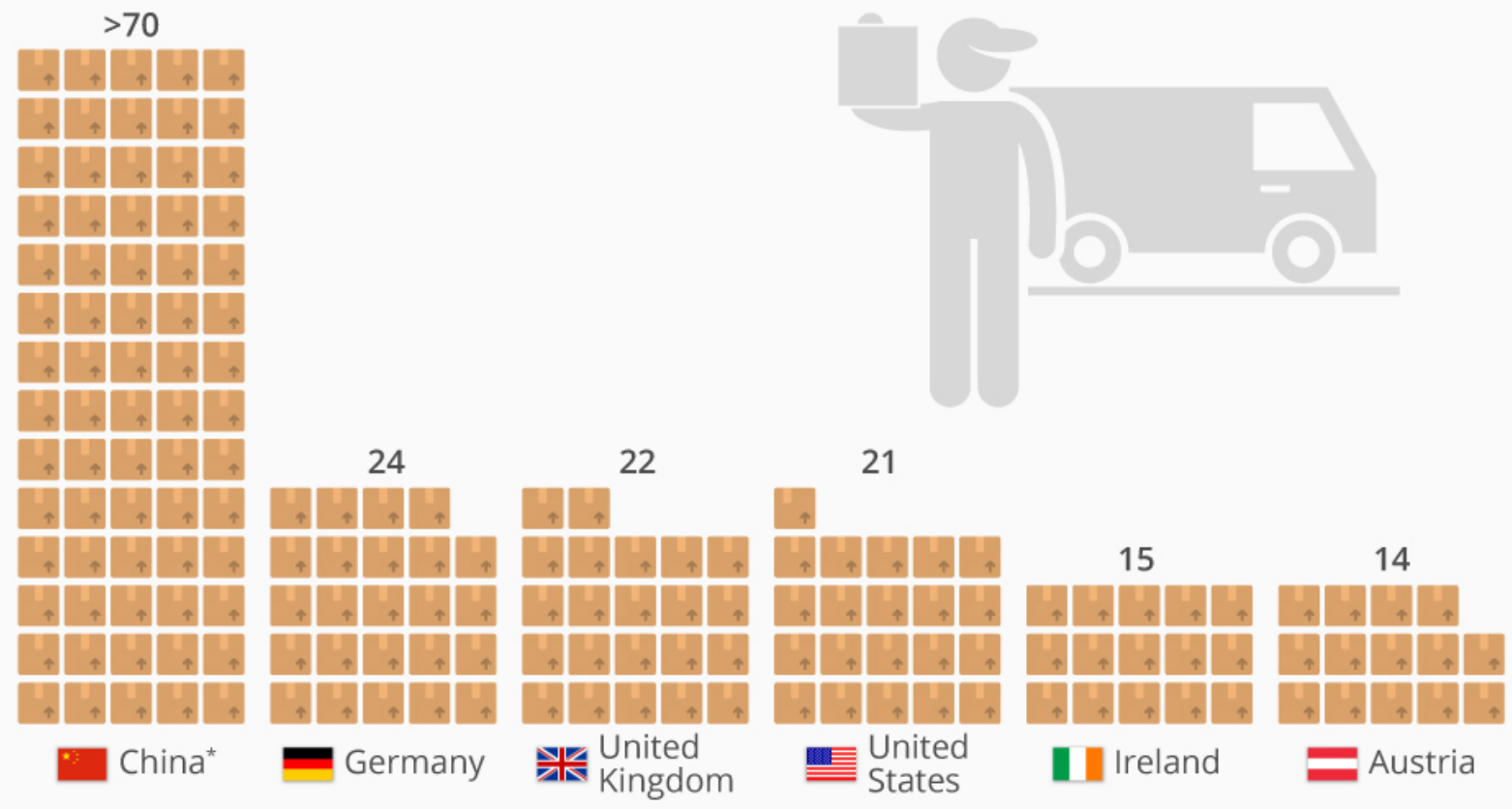

12
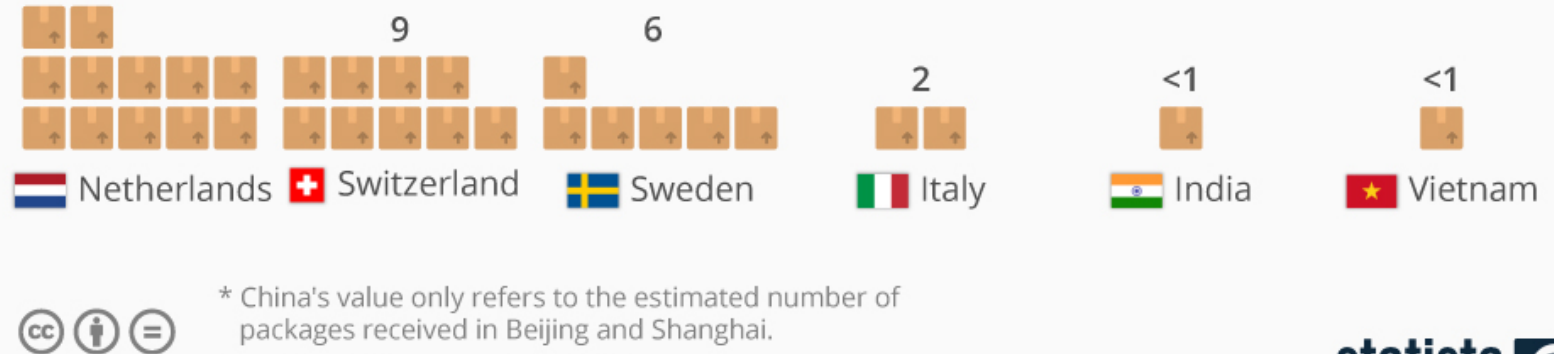

* China's value only refers to the estimated number of packages received in Beijing and Shanghai.

@StatistaCharts Source: McKinsey via Der Spiegel

\section{statista}

Source: Statista accessed at https://www.statista.com/chart/18396/average-number-of-parcels-receivedper-person/.

\subsubsection{Changes in goods and meal delivery}

According to Statista, United States residents will spend over $\$ 22$ billion on online food delivery in 2019, and food delivery companies should experience an average annual growth rate of revenues at 5.3\% between 2019 and 2023. Numerous companies are connecting people to goods and food, including Postmates, Caviar, GrubHub, UberEats, and many more. In just four years (2014-2018), UberEats expanded to 280 cities (Kludt 
and Geneen, 2018). The USDA reports that almost $55 \%$ of total food purchases were spent away from home in 2018.

Figure 3-2: Food delivery by Jump e-bike, San Francisco, 2019

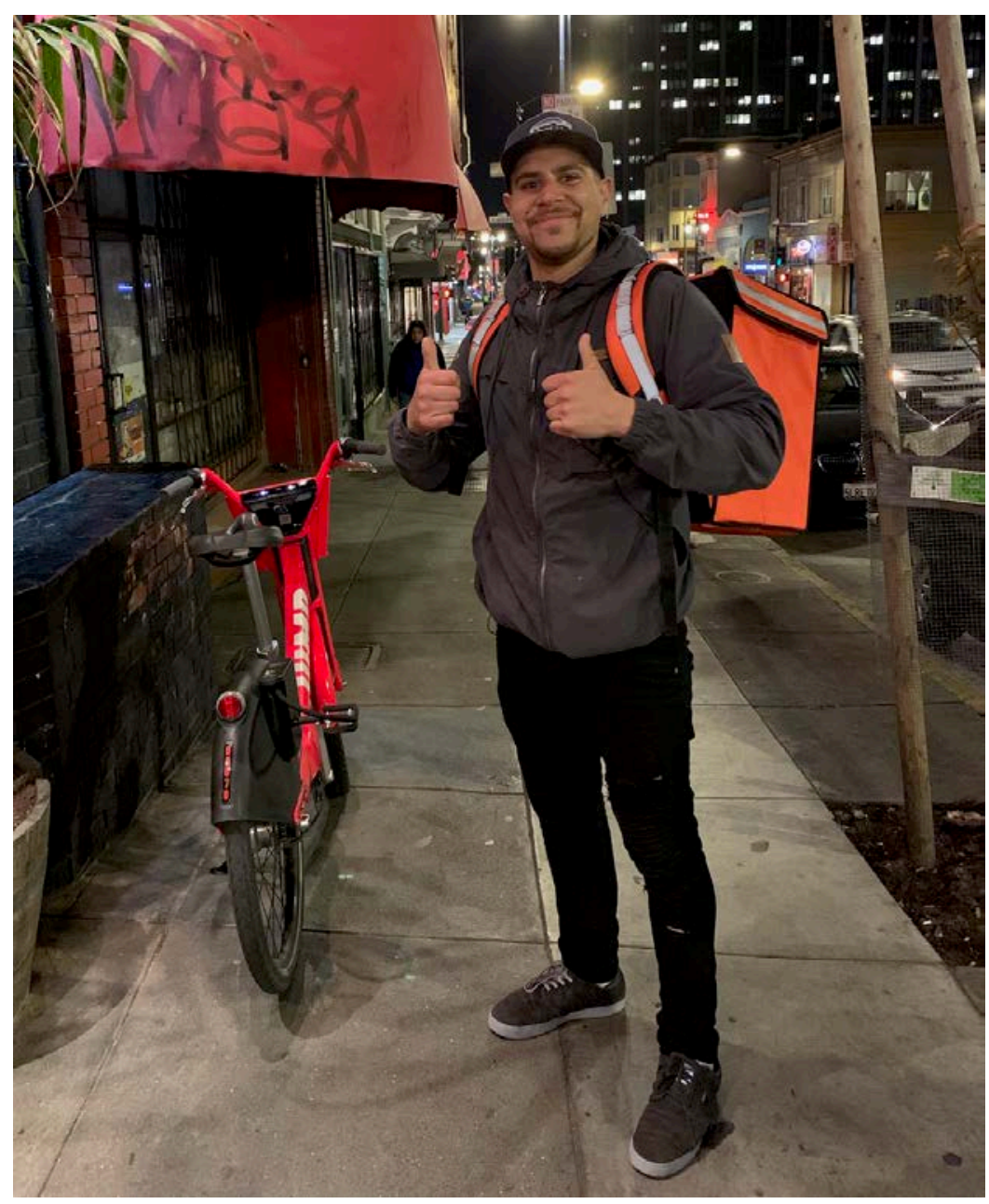

Photo: Jennifer Davidson for the Urbanism Next Center, 2019.

\subsubsection{Increased demand for warehousing and distribution space}

As e-commerce expands, from 4.2\% in the first quarter of 2010 to $10.7 \%$ in the first quarter of 2019 (U.S. Department of Commerce and U.S. Census Bureau, 2019), the need for additional warehouse space is also increasing. Companies, including Amazon, are building warehouses to move goods even closer to consumers (Cerasis, 2018). According to MWPVL International, Amazon currently has 426 active facilities with $155,819,048$ square feet, and another 66 facilities with 31,487,241 square feet are planned. 


\subsubsection{Reduction in certain types of brick-and-mortar stores}

Many types of big box retail companies have struggled over the past several years, and brands like Sears and Payless Shoe Store are declaring bankruptcy and closing thousands of stores. All told, approximately 8,200 stores are expected to close in 2019 (Peterson, 2019). To stay competitive, Walmart invested over $\$ 3.3$ billion in ecommerce sales and saw sales increase 63\% by Q2 2017 (Bowman, 2017).

\subsubsection{Rise in experiential retail}

While traditional big box retail has struggled, experiential retail that provides an interactive or technology-enhanced experience in stores has fared better. One of the best examples of a successful experiential store is Apple, which seeks to mirror the sleek design of its products inside its stores. Cushman and Wakefield cite five factors that are challenging traditional retail (G. Brown, 2019):

1. Acceleration of newCommerce

2. Over-retailed marketplace

3. The rise of the discounters

4. Shifting consumer patterns (millennials spending differently than past generations)

5. Outdated financial models from Wall Street and private equity

While e-commerce is not the only trend impacting traditional brick-and-mortar stores, other trend listed above also make the retail environment challenging and point to the advantage that experiential stores provide.

\subsection{IMPLICATIONS OF CHANGE}

The forces of change described in this chapter focus primarily on how emerging technologies could potentially impact the built environment. These changes also have implications on equity, health, the economy, the environment, and governance.

\subsubsection{Equity}

It remains to be seen how the forces of change will impact equity. People with disabilities, seniors, youth, and others who cannot, should not, or do not want to drive or own a car may find it much easier to take trips through new mobility services or to receive deliveries (Harb et al., 2018). Or, new mobility services could result in people who are already transportation rich benefitting disproportionately, thereby increasing inequality (Asenjo et al., 2017; McLaughlin, 2017). And while new mobility services may increase reliable transportation for job interviews or other time-sensitive activities, there is the potential for AVs in particular to put millions of people who drive or have cardependent jobs out of work (Groshen et al., 2018; World Economic Forum, 2018). 


\subsubsection{Health}

There are a number of ways that new mobility services could improve or jeopardize health. AVs could dramatically reduce the number of fatal crashes and serious injuries. Approximately $90 \%$ of automobile crashes are caused by human error and AVs could significantly reduce those crashes (Fagnant and Kockelman, 2014b). In addition, if new mobility services result in a dramatic reduction in the demand for parking, communities that aggressively pursue infill could increase walkability and bikability in their community (Richland, Lee and Butto, 2016). However, if we substitute AVs for walking, biking, and transit use like we are for TNCs (Clewlow and Mishra, 2017), people could reduce the amount of exercise that they get. In addition, if the reduced friction of taking an AV results in people choosing to live much farther away from where they work, shop, or play, then they could become more sedentary (Ding et al., 2014).

\subsubsection{Economy}

The TNC industry has significantly impacted taxi companies and jeopardized the livelihood of taxi drivers in New York City, as well as around the country and around the world (Schaller, 2018). According to CB Insights Research (2010), about 33 industries could experience significant upheaval from AVs. Sectors that rely on personally owned vehicles, from car insurance to auto dealers and car washes to restaurants, that find more people ordering home delivery will be impacted. Even real estate, military operations, and home improvement could experience significant shifts.

\subsubsection{Environment}

Whether or not AVs reduce greenhouse gas emissions (GHG) depends in part on the adoption of electric vehicles. Electric vehicles generally emit $40 \%$ fewer GHG emissions than conventional vehicles (Gawron et al., 2018), and could have a net beneficial environmental effect (Requia et al., 2018). If the adoption of AVs result in more sprawl, then we could see a loss of habitat and environmental services. In contrast, reduced dependence on vehicles could result in much denser cities, which would make it easier to walk, bike, and take transit. It remains to be seen if new mobility services result in positive or negative environmental impacts.

\subsubsection{Governance}

New mobility technologies are challenging the resources and processes that city, county, and state governments have in place to manage transportation. Cities are creating new policy and regulations to manage TNCs, micromobility and, eventually, AVs. Given the fast pace of change, some cities are adapting their processes to quickly address opportunities as well as challenges. For example, the City of Los Angeles created a "prequalified" Tech Bench of consultant and vendors. Many cities are considering public-private partnerships or even privatizing some functions (Krawiec and White, 2017). Even more profound may be the fiscal implications of new mobility services. In 2017, Governing examined the revenues of the 25 largest cities in the U.S. and determined that AVs may disrupt up to $\$ 5$ billion in revenues (Governing, 2018). 


\subsection{POLICY ASSESSMENT}

This chapter is the policy assessment in Section 3 and Section 4 of the Navigating New Mobility Report (Urbanism Next Center, 2019). The authors first analyzed the top ten new mobility policy topics found in national examples of new mobility strategies (publicly available in March 2019) that help to take advantage of opportunities and challenges identified in Chapter 3. The authors then reviewed existing transportation, environmental, and related policy documents in the Cities of Gresham and Eugene to identify existing policy guidance, opportunities for modest changes to address new mobility, and gaps related to the top ten new mobility policy topics addressed in new mobility strategies. This analysis illustrates and highlights how other cities can evaluate their existing policies to craft new mobility policies that help communities ensure that new mobility helps them achieve community goals.

\subsection{NATIONAL NEW MOBILITY POLICIES ASSESSMENT}

Government agencies at the federal, state, and local level are just beginning to address the challenges and opportunities presented by emerging technologies and new mobility services. Cities are considering these impacts and framing their new mobility policies within existing transportation, land use, sustainability, social equity, and other goals. Some cities and organizations developed or are developing strategies and guidance first, such as the City of Seattle's New Mobility Playbook or the Shared Mobility Principles for Livable Cities created by Robin Chase and adopted by public and private organizations. Others are using existing land use, transportation, or other documents and updating elements of these policies to accommodate new mobility. This chapter describes some of the most common topics included in new mobility strategies and implementation regulations across the country, such as improving safety, prioritizing active transportation, and improving social equity. This chapter breaks it down into 10 topic areas:

1. Safety

2. Social equity

3. Active transportation

4. Congestion and vehicle miles traveled

5. Sustainability and environmental impacts

6. Design and management of the right-of-way (ROW)

7. Land use and metropolitan footprint

8. Informed decision making

9. Manage innovation

10. Fiscal impacts and new mobility revenue

These ten topic areas were chosen because they were commonly found in new mobility policy documents listed in Table 4-1. These topic areas were then used to scan community goals in the City of Gresham and Eugene's land use, transportation, economic development, and environmental plans, discussed in greater detail in this chapter. Urbanism Next researchers scanned the cities' policy documents and identified 
goals, objectives, and action items related to these topics. For example, both cities have multiple goals related to promoting active transportation - walking, biking, and transit. Coupled with the fact that most new mobility policy documents and implementing measures also support active transportation made it logical to include it in this section and provide examples from the policy documents listed in Table 4-1. This list of documents and the sample policies should not be considered exhaustive, but is designed to provide an example of the types of policies that other jurisdictions are considering.

Table 4-1: Sample of new mobility policies and implementing regulations

\begin{tabular}{|c|c|c|c|c|}
\hline Jurisdiction & Name & Date & Agency/Group & Description \\
\hline Atlanta, GA & $\begin{array}{l}\text { Regional } \\
\text { Transportation } \\
\text { Technology Policy } \\
\text { Document }\end{array}$ & Dec 2016 & $\begin{array}{l}\text { Atlanta Regional } \\
\text { Commission }\end{array}$ & $\begin{array}{l}\text { Policy and strategy } \\
\text { recommendations }\end{array}$ \\
\hline \multirow{2}{*}{ Austin, TX } & $\begin{array}{l}\text { Smart Mobility } \\
\text { Roadmap }\end{array}$ & Oct 2017 & $\begin{array}{l}\text { City of Austin and } \\
\text { Capital Metro }\end{array}$ & $\begin{array}{l}\text { Policy and strategy } \\
\text { recommendations }\end{array}$ \\
\hline & $\begin{array}{l}\text { Austin Strategic } \\
\text { Mobility Plan }\end{array}$ & No Date & City of Austin & Draft policies \\
\hline Chandler, AZ & $\begin{array}{l}\text { Ridesharing and } \\
\text { Autonomous Vehicles } \\
\text { Zoning Code } \\
\text { Amendments }\end{array}$ & $\begin{array}{l}\text { May } \\
2018\end{array}$ & City of Chandler & $\begin{array}{l}\text { Adopted parking to } \\
\text { passenger loading ratio } \\
\text { zoning code updates }\end{array}$ \\
\hline $\begin{array}{l}\text { Denver } \\
\text { Metropolitan } \\
\text { Region }\end{array}$ & $\begin{array}{l}2030 \text { Mobility Choice } \\
\text { Blueprint }\end{array}$ & Nov 2018 & Denver Region & $\begin{array}{l}\text { Policy and strategy } \\
\text { recommendations }\end{array}$ \\
\hline \multirow{2}{*}{$\begin{array}{l}\text { Los Angeles, } \\
\text { CA }\end{array}$} & $\begin{array}{l}\text { Urban Mobility in a } \\
\text { Digital Age }\end{array}$ & 2016 & $\begin{array}{l}\text { LA Dept. of } \\
\text { Transportation }\end{array}$ & $\begin{array}{l}\text { Policy and strategy } \\
\text { recommendations }\end{array}$ \\
\hline & Mobility Plan 2035 & $\begin{array}{l}\text { Sept } \\
2016\end{array}$ & $\begin{array}{l}\text { Dept. of City } \\
\text { Planning }\end{array}$ & $\begin{array}{l}\text { Adopted as part of the } \\
\text { General Plan in } 2016\end{array}$ \\
\hline $\begin{array}{l}\text { Metro Region, } \\
\text { OR }\end{array}$ & $\begin{array}{l}\text { Draft Emerging } \\
\text { Technology Strategy }\end{array}$ & $\begin{array}{l}\text { June } \\
2018\end{array}$ & Metro & $\begin{array}{l}\text { Policy and strategy plan, } \\
\text { incorporated into the } \\
\text { Regional Transportation } \\
\text { Plan }\end{array}$ \\
\hline $\begin{array}{l}\text { Miami-Dade } \\
\text { County }\end{array}$ & $\begin{array}{l}\text { Urban Mobility } \\
\text { Playbook }\end{array}$ & $\begin{array}{l}\text { March } \\
2016\end{array}$ & $\begin{array}{l}\text { Miami-Dade } \\
\text { County and City } \\
\text { Innovate } \\
\text { Foundation }\end{array}$ & $\begin{array}{l}\text { Policy and strategy } \\
\text { recommendations }\end{array}$ \\
\hline $\begin{array}{l}\mathrm{NY} / \mathrm{NJ} / \mathrm{CT} \\
\text { Region }\end{array}$ & $\begin{array}{l}\text { New Mobility: AVs and } \\
\text { the Region (Component } \\
\text { of Fourth Regional } \\
\text { Plan) }\end{array}$ & Oct 2017 & $\begin{array}{l}\text { Regional Plan } \\
\text { Association }\end{array}$ & $\begin{array}{l}\text { Policy and strategy } \\
\text { recommendations } \\
\text { included in the Fourth } \\
\text { Regional Plan (Nov } \\
2017 \text { ) }\end{array}$ \\
\hline Portland, OR & $\begin{array}{l}\text { Portland } 2035 \\
\text { Transportation System } \\
\text { Plan }\end{array}$ & $\begin{array}{l}\text { May } \\
2018\end{array}$ & City of Portland & Policies and strategies \\
\hline Seattle, WA & New Mobility Playbook & $\begin{array}{l}\text { Sept } \\
2017\end{array}$ & $\begin{array}{l}\text { Seattle Department } \\
\text { of Transportation }\end{array}$ & $\begin{array}{l}\text { Policy and strategy } \\
\text { recommendations }\end{array}$ \\
\hline $\begin{array}{l}\text { St. Louis, MO } \\
\text { Region }\end{array}$ & $\begin{array}{l}\text { Emerging } \\
\text { Transportation } \\
\text { Technology Strategic } \\
\text { Plan }\end{array}$ & $\begin{array}{l}\text { June } \\
2017\end{array}$ & $\begin{array}{l}\text { East-West } \\
\text { Gateway COG }\end{array}$ & $\begin{array}{l}\text { Policy and strategy } \\
\text { recommendations }\end{array}$ \\
\hline
\end{tabular}

Source: Urbanism Next Center, 2019. 


\subsubsection{Safety}

Cities with Vision Zero policies (or their equivalents) must now consider how new mobility services could help them achieve community safety goals. Here are examples of cities incorporating Vision Zero goals into new mobility strategies and policies:

- City of Portland. The City of Portland's Transportation Plan was updated in 2018. Policy 9.68.a. states that the city should "[e]nsure that all levels of automated vehicles advance Vision Zero by operating safely for all users, especially vulnerable road users." (City of Portland, Bureau of Transportation, 2018).

- City of Seattle. New Mobility Playbook, Strategy 2.2 states the city will, "Ensure that new mobility advances our Vision Zero goal of ending traffic deaths and serious injuries on city streets by 2030." (Seattle Department of Transportation, 2017) (Also see Social Equity Examples.)

- City of San Francisco. San Francisco's Guiding Principles for Emerging Technologies state, "Emerging Mobility Services and Technologies must be consistent with the City and County of San Francisco's goal for achieving Vision Zero, reducing conflicts, and ensuring public safety and security." (San Francisco Municipal Transit Agency, 2017).

\subsubsection{Social equity}

Cities are adopting a number of approaches to include equity issues. Some of the most common are:

- Provide a seat at the table. Include a diversity of people to ensure that equity is addressed in plans and strategies as well as implementing regulations. The City of Austin is proposing a policy to partner with the public and private sectors to create new mobility solutions for historically underserved communities (City of Austin. n.d.).

- Ensure all areas are covered by the service. Some cities require new mobility services be available to all residents, regardless of where they live. More and more, cities are requiring companies to disperse their vehicles (bike, e-scooter, or other vehicles) in low-income or underserved neighborhoods or across the entire city. During Portland's e-scooter pilot that ran from July to November 2018, the permit required that each of the three companies participating in the pilot deploy 100 e-scooters in the historically underserved neighborhoods of East Portland. Only one company regularly complied with this requirement. The report found that, "many Black Portlanders and East Portlanders expressed enthusiasm and support for e-scooters, focus group participants also expressed an overall concern with traffic safety and being targeted for racial profiling and harassment. The prohibitive cost of renting and a lack of knowledge of e-scooter laws and low-income plans also presented barriers to use."(Portland Bureau of 
Transportation, 2019, p 25). Other cities require a minimum number of vehicles in each neighborhood or designated zone. Washington, D.C., requires companies to put e-scooters in every ward, though companies complained that the capping of the total number of e-scooters makes this difficult (Dalgadillo, 2018).

- Require diverse payment options. Some jurisdictions require companies to provide a payment option that does not include a smart phone or credit card, or that waives deposits for low-income people. Washington, D.C., requires companies to offer unlimited 30 -minute trips to customers that are at $200 \%$ of the federal poverty level.

- Ensure that companies promote equitable workforce policies. Ensure that companies reflect the community they serve and offer fair pay, labor policies, and practices.

- Accommodate people with disabilities. Several cities encourage companies to provide options for people with disabilities, such as Washington, D.C.'s adaptive e-scooters.

Examples of cities incorporating equity into new mobility strategies and policies:

- City of Seattle. Seattle's New Mobility Playbook includes principles, plays, and actions to improve safety. The principles put people and safety first: "Safety is paramount, no matter how you get around Seattle. Our streets should be comfortable and intuitive for our most vulnerable travelers (people walking and biking). Shared, automated, and other new mobility models should not only advance our Vision Zero safety goals, they should also maintain consumer protections." (Seattle Department of Transportation, 2017, p 32). Play 1 is to ensure a fair and just transportation system for all. The strategies in this play include enhancing transportation services for vulnerable groups such as the LGBTQ community, youth, seniors, people with disabilities, and many others; ensure everyone can access smart phone services; ensure a wide array of payment options; make sure new mobility services are ADA accessible, and more.

- Washington, D.C. The District adopted a new e-scooter and motorized bicycle permit (effective January 1,2019 ) that requires e-scooter coverage in every ward (eight total), and allows up to 600 e-scooters per company with the potential to increase that amount by $25 \%$ every three months. In addition, companies are encouraged to offer adaptive vehicles that can accommodate people with mobility devices (like wheelchairs). These vehicles are not counted towards the total allowed (District Department of Transportation, 2018).

\subsubsection{Active transportation (Walk, bike, e-scooter, transit)}

Cities and transit agencies are considering the impact new mobility services are having on active transportation systems. While many cities include goals related to promoting pedestrian, bicycle, and transit systems and reducing reliance on single-occupancy 
vehicles, some cities are taking the next step to prioritize walking, biking and transit over vehicles with a focus on reducing single-occupancy and zero-occupancy vehicles. Table 4-2 shows the prioritization of modes for the cities of Portland and Victoria, BC.

Table 4-2: Prioritization of modes, Portland, OR, and Victoria, BC, 2019

\begin{tabular}{l|l|l}
\hline Priority & Portland, OR & Victoria, BC \\
\hline 1 & Walking & Pedestrians \\
\hline 2 & Biking & Cyclists \\
\hline 3 & Transit & Transit \\
\hline 4 & $\begin{array}{l}\text { Fleet automated vehicles that are electric and } \\
\text { shared (FAVES) }\end{array}$ & Commercial vehicles \\
\hline 5 & Other shared vehicles & Single-occupancy vehicles \\
\hline 6 & $\begin{array}{l}\text { Low- or no-occupancy vehicles, fossil-fueled non- } \\
\text { transit vehicles }\end{array}$ & \\
\hline
\end{tabular}

Source: City of Portland, Portland 2035 Transportation System Plan (2018). City of Victoria, BC, Official Community Plan, Section 7: Transportation and Mobility, p 52.

Prioritizing active transportation draws a direct connection between policy goals related to safety, health, reducing greenhouse gases, complete streets, and sustainable and livable cities that support higher-intensity uses and guides infrastructure investments. It also informs the implementation of Complete Streets and curb management policies to reduce conflicts between new mobility service providers and vehicles, pedestrians, bicyclists, and transit riders, as well as goods delivery and courier services. It clearly states that implementation strategies that prioritize walking, biking, and transit will take precedence over vehicles. Here are examples of how cities are incorporating these concepts into policies:

- City of Portland. Portland recently updated its Transportation System Plan (TSP) and identifies reducing GHG emissions by reducing low occupancy "empty miles" as well as prioritizing electric and other zero emission vehicles. (City of Portland, Bureau of Transportation, 2018, TSP Policy 9.68.b.)

- City of San Francisco. San Francisco's SFMTA has the Transit First policy, which prioritizes pedestrian modes. The city is attempting to evaluate its curb management approach by using data collection and implementing a "decongestion pricing and incentives system" with either cordons or roadway user fees. The SFMTA has also embarked on a "Powered E-Scooter Share Permit Program" and is attempting to regulate e-scooter clutter in the ROW. An evaluation of restricted parking curb location data determined that approximately $20 \%$ of microtransit stops are located in unauthorized zones. The report has a number of recommendations related to congestion and curb pricing, but there's not a lot of specific deliverables on precise ordinance or pilot suggestions.

- NY/NJ/CT Regional Plan Association. The NY/NJ/CT Regional Plan Association identified the need to prioritize street space for public transit, pedestrians, bikes, and freight in the 2017 New Mobility report. 


\subsubsection{Congestion and vehicle miles traveled}

Almost every new mobility strategy or plan includes a goal to keep people and goods moving. The potential for TNCs and AVs to dramatically increase congestion and VMT is concerning. Numerous reports have documented an increase in TNCs and the corresponding increase in congestion and reduced traffic speeds ("Emerging Mobility," n.d.; Fehr \& Peers, 2018a; Schaller, 2018) as well as a reduction in transit use (Graehler Jr., Mucci and Erhardt, 2019). Given the potential for increased congestion and VMT, cities are considering efforts that reduce congestion and promote shared vehicles.

NACTO's report Blueprint for an Autonomous Future (2017) provides a vision for how cities can design streets to increase throughput while promoting active transportation and autonomous transit. Figure 4-1 shows that streets designed for high-capacity AV transit service could move over 47,000 more people per hour than auto-oriented streets (NACTO, 2017).

Figure 4-1. Conceptual street capacity of different modes, Wilshire Blvd, Los Angeles, 2017

Present
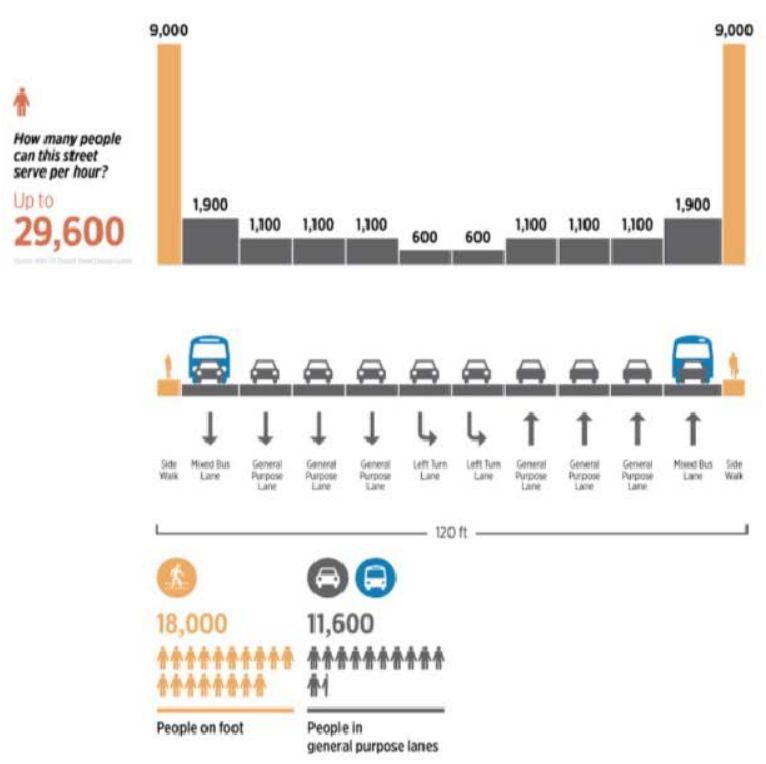

\section{Future}

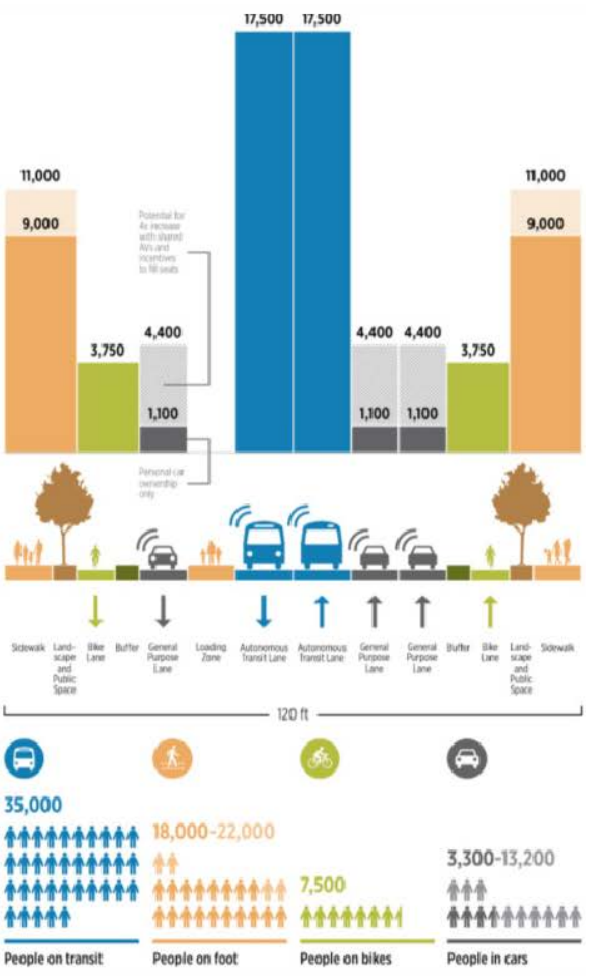

Source: Perkins\&Will/Nelson Nygaard, Lyft Wilshire Blvd. Study, 2017 
At the policy guidance level, the cities of Portland, OR, Seattle, WA, and Vancouver, $B C$, have all indicated they will prioritize shared, electric and autonomous vehicles.

Other potential strategies are to price single-occupancy or zero-occupancy vehicles at a higher rate than shared vehicles. To our knowledge this idea is conceptual as of early 2019 , as most cities and airports charge TNCs by the ride, and the only company offering commercial AV services is Waymo in Chandler, AZ, (as of December 2018) and does not charge a city fee for each ride.

Another tactic is to price the curb higher at the most desirable pick-up/drop-off locations. For example, the San Francisco Airport charges TNCs \$5 to pick-up/drop-off passengers in front of the terminals (the most convenient location), or $\$ 3.60$ to get picked up/dropped off on the top level of the parking garage.

- City of Portland. The City of Portland's Transportation System Plan states that to "ensure that connected and automated vehicles improve travel time reliability and system efficiency by: (1) maintaining or reducing the number of vehicle trips during peak congestion periods; (2) reducing low occupancy vehicle trips during peak congestion periods; (3) paying for use of, and impact on, Portland's transportation system including factors such as congestion level, vehicle miles traveled, vehicle occupancy, and vehicle energy efficiency; and (4) supporting and encouraging use of public transportation."(City of Portland, Bureau of Transportation, 2018, TSP Policy 9.68.b.)

\subsubsection{Sustainability and environmental impacts}

Cities across the country understand that new mobility services provide a new opportunity to decrease GHG emissions, air pollution, and possibly improve stormwater management. Example policies are:

- City of Portland. Transportation System Plan Policy 9.68.c. is "Cut vehicle carbon pollution by reducing low occupancy 'empty miles' traveled by passenger vehicles with zero or one passengers. Prioritize electric and other zero direct emission vehicles operated by fleets and carrying multiple passengers."(City of Portland, Bureau of Transportation 2018).

- Denver region. The Mobility Choice Blueprint identified promotion of electrification of vehicles as one of its strategies to reduce GHG emissions and air pollution. The tactical actions are:

o "5.1. Incentivize TNCs to use electric vehicles. Develop a goal, create a policy and incentivize the deployment and use of electric and other zeroemission vehicles by TNCs.

o 5.2. Create an electrified mobility development program. Identify regulatory hurdles and develop recommendations to encourage the adoption of electrified vehicles by public and private fleets. 
o 5.3. Transition government fleets to electric and other zero-emission vehicles. Work with public agencies to create an aggressive and agreedupon goal for converting a portion of their fleets to zero-emission vehicles. The goals may be tailored to fleet types as well as available vehicle technology."(Colorado Department of Transportation et al., 2018).

\subsubsection{Design and management of the right-of-way}

Emerging technologies and new mobility services are disrupting how the right-of-way the space from sidewalk to sidewalk - is being used. Researchers from the Association of Pacific Rim Universities (APRU) and the University of Oregon through the Sustainable Cities and Landscapes Research Hub identified two ways that AVs (and some new mobility services) may free up street space (Schlossberg and Riggs, 2018):

1. Lanes. Both the number of lanes and the amount of space needed may shrink as AVs are "right-sized" to fit the need and more vehicles are shared, as well as the ability of AVs to travel close together in a platoon.

2. Parking. As more people rent or share the ride and fewer use personally owned vehicles, the demand for parking should go down.

Both of these trends allow for cities to reclaim space in the ROW for other uses. The authors of the report imagine regaining approximately 24 feet on a typical urban arterial by removing one lane of parking and reducing lane widths to 8 feet. The reclaimed space could be used for loading zones, widened sidewalks, dedicated transit, or increased bike/e-scooter lanes.

NACTO's Blueprint for Autonomous Urbanism provides even more detail about how cities should think about autonomous vehicles (NACTO, 2017). NACTO envisions a future where streets are prioritized for pedestrians, bicyclists, and transit riders.

The City of Portland's hierarchy of modes sets an overarching policy that prioritizes streets and street networks for pedestrians, bikes, transit, and freight above private vehicles or single-occupancy vehicles. A similar policy is identified in the NY/NJ/CT Regional Plan Association New Mobility and Seattle's New Mobility Playbook.

From adjacent store owners advocating for free parking for customers and employees, to commercial delivery companies demanding parking for trucks, to active transportation advocates requesting protected space to walk, bike, and take transit, battles over the curb are nothing new. What is new is the explosion of dockless bikes and e-scooters where they've been introduced and TNC services, along with the anticipation of AVs, that is convincing cities that they must develop new systems to manage, and price, the curb. 
Cities rarely have a comprehensive picture of how the curb is being used. Data requirements for new mobility providers helps cities understand the demand for the curb, but not all cities require data sharing. A study completed in 2018 by Uber and Fehr \& Peers quantified the demand for the curb in five locations with significant TNC dropoff/pick-up in San Francisco. Figure 4-2 highlights the most efficient mode for moving people is by bus, with 481 people observed dropped off or picked up by 69 vehicles, compared to 432 people in 370 vehicles for TNCs or private vehicles. Twenty-three parked cars transported 23 people.

Figure 4-2: Vehicles and people by mode, per hour, San Francisco Curb Study, Five Case Study Sites, 2018

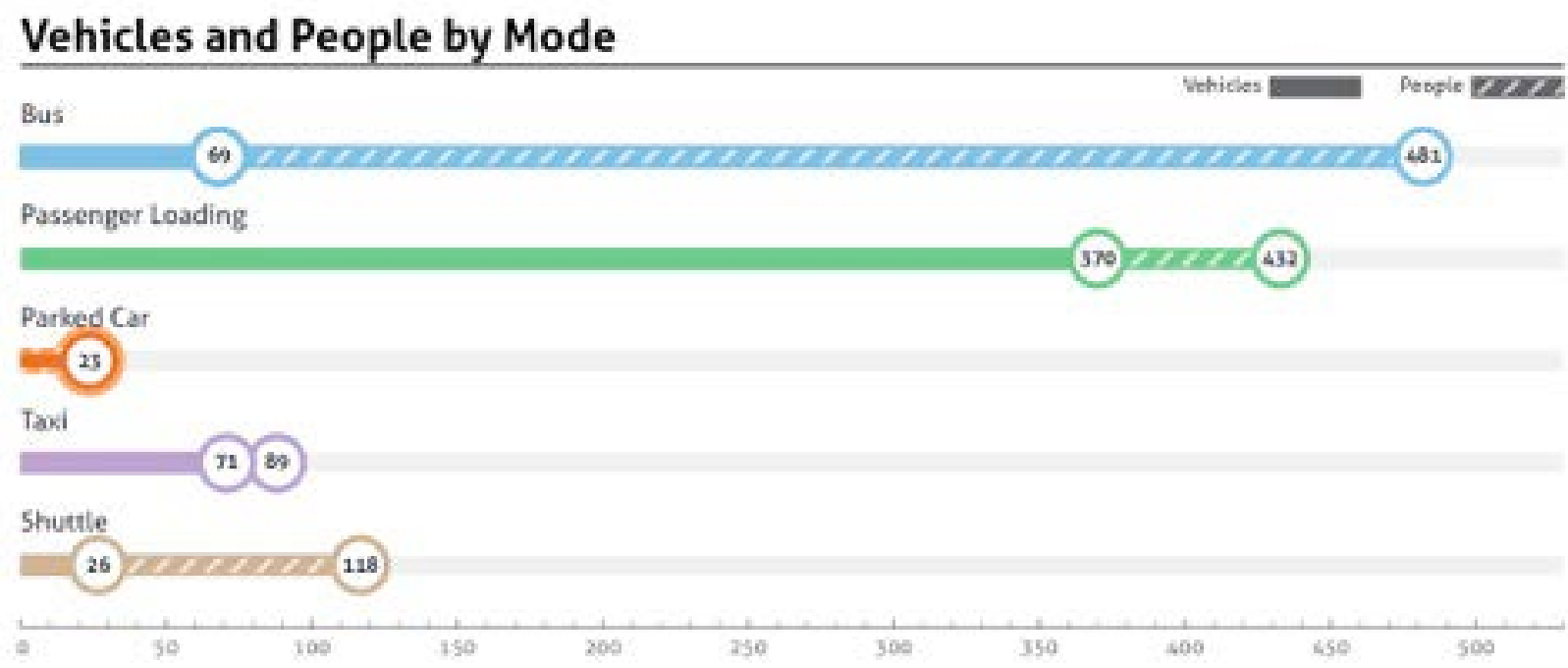

Source: Fehr \& Peers, San Francisco Curb Study prepared for Uber Technologies, September 2018., p 39.

As the demand for the curb increases, cities are increasingly accepting that they may need to change how they manage the right-of-way and curb space. For example, some cities that have neighborhoods with a lot of nightlife are removing on-street parking and replacing it with loading zones. Cities are also starting to rethink the condition of their bike lanes as e-scooters descend on cities and riders who are uncomfortable riding on the street (often due to poor conditions or unprotected bike lanes) instead are riding on the sidewalk. Some e-scooter companies are advocating for better bike infrastructure (Sisson, 2018a) and cities are starting to think about and plan for e-scooter parking (see Figure 4-3). Some cities are considering removing on-street parking, designing dockless e-scooter and bike parking, and eventually regulating the use of sidewalks and streets for terrestrial drones, such as those by Starship (see Figure 4-4). 
Figure 4-3: Dockless bike and e-scooter parking, City of Santa Monica, 2018

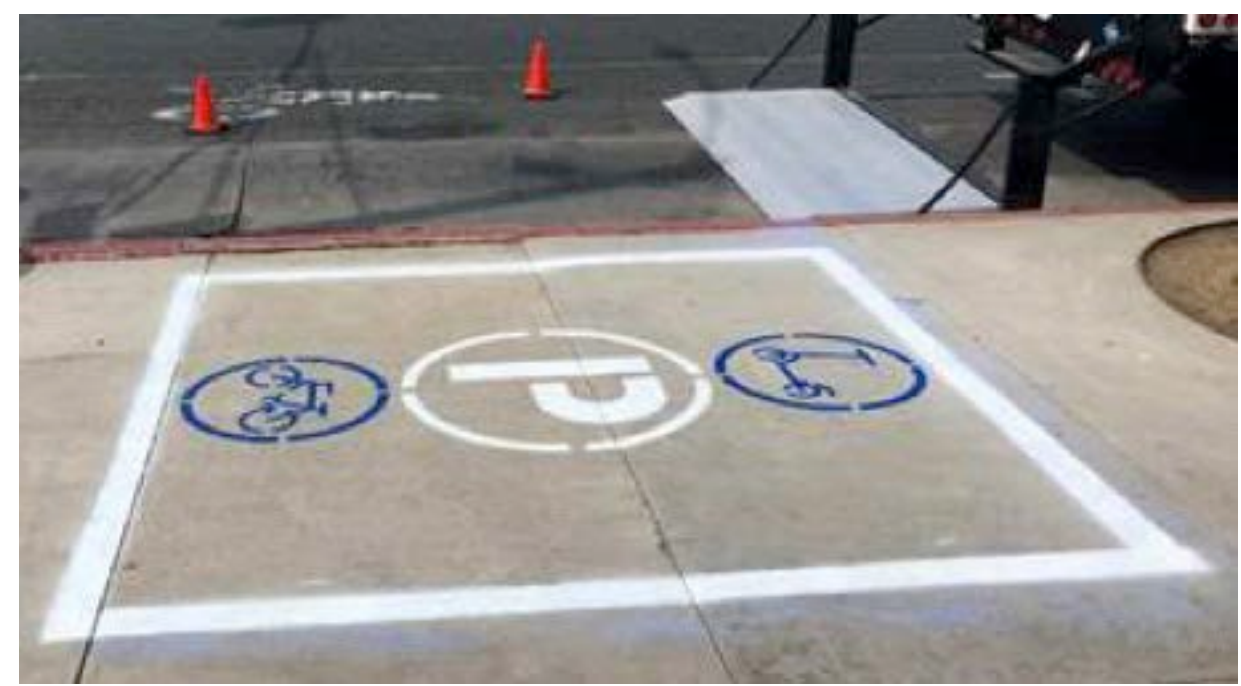

Source: City of Santa Monica, 2018. Accessed at https://www.santamonica.gov/blog/5-things-to-knowbefore-you-ride-an-electric-scooter on December 18, 2018.

Figure 4-4: Starship terrestrial drone

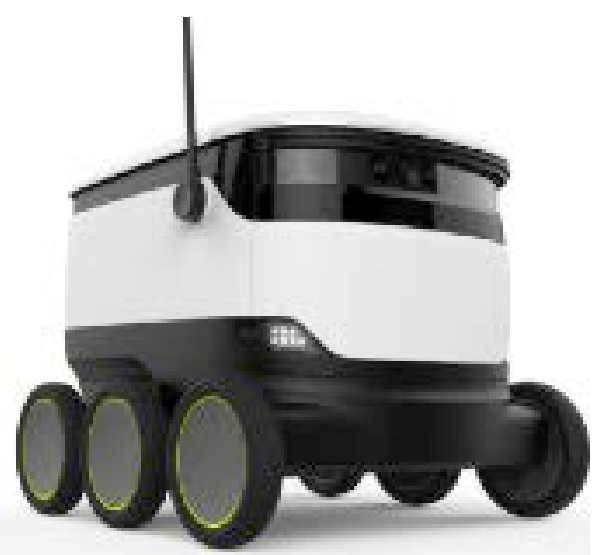

Source: Starship, 2018. Accessed at https://www.starship.xyz/kit/ on December 18, 2018.

Only a few cities have developed a comprehensive ROW and curb management system and, of those, they are still adapting their systems for new mobility modes. For example, the City of Seattle has identified six functions of the ROW as storage, greening, activation, access for commerce, access for people, and mobility, as shown in Figure 45. Figure 4-6 describes the pedestrian zone, the flex zone, and the travel way. 
Figure 4-5: Primary functions of the right-of-way as defined by the Seattle Department of Transportation, 2016

\begin{tabular}{|c|c|c|c|c|c|c|}
\hline FUNCTION & STORAGE & GREENING & ACTIVATION & $\begin{array}{l}\text { ACCESS FOR } \\
\text { COMMERCE }\end{array}$ & $\begin{array}{c}\text { ACCESS FOR } \\
\text { PEOPLE }\end{array}$ & MOBILITY \\
\hline DEFINITION & $\begin{array}{l}\text { Provides storage } \\
\text { for vehicles or } \\
\text { equipment }\end{array}$ & $\begin{array}{l}\text { Enhances } \\
\text { aesthetics and } \\
\text { environmental } \\
\text { hesith }\end{array}$ & $\begin{array}{l}\text { Offers vibrant } \\
\text { social spaces }\end{array}$ & $\begin{array}{l}\text { Goods and } \\
\text { services reach } \\
\text { their customers } \\
\text { and markets }\end{array}$ & $\begin{array}{l}\text { Pesple arrive at } \\
\text { their destination, } \\
\text { or transfer } \\
\text { between different } \\
\text { ways of getting } \\
\text { around }\end{array}$ & $\begin{array}{l}\text { Moves people and } \\
\text { goods }\end{array}$ \\
\hline USES & $\begin{array}{l}\text { Bus layowar } \\
\text { Leng-term } \\
\text { parking } \\
\text { Reserved spaces } \\
\text { le.g-for Police or } \\
\text { other government } \\
\text { usel } \\
\text { Construction }\end{array}$ & $\begin{array}{l}\text { Plantings } \\
\text {-Boulewards } \\
\text {-5lreet trees } \\
\text {-Planter boxes } \\
\text { Rain gardens and } \\
\text { bio-swoles }\end{array}$ & $\begin{array}{l}\text { Food trucks } \\
\text { Parklets and } \\
\text { streateries } \\
\text { Public art } \\
\text { Stroet festivals }\end{array}$ & $\begin{array}{l}\text { Commercial } \\
\text { vehicle load zonts } \\
\text { Truck losd zone }\end{array}$ & $\begin{array}{l}\text { Bus or rail staps } \\
\text { Bike parking } \\
\text { Curb bulbe } \\
\text { Pasenger load } \\
\text { zones } \\
\text { Short-term parking } \\
\text { Taxi zanes }\end{array}$ & $\begin{array}{l}\text { Sidewalks } \\
\text { Bus or streetcar } \\
\text { lanes } \\
\text { Bike lanes } \\
\text { General purpose } \\
\text { trawel lanes } \\
\text { Right ar lett } \\
\text { turn-only lanes }\end{array}$ \\
\hline
\end{tabular}

Source: City of Seattle. Accessed at http://streetsillustrated.seattle.gov/street-types/row-allocation/ on December 18, 2018. 


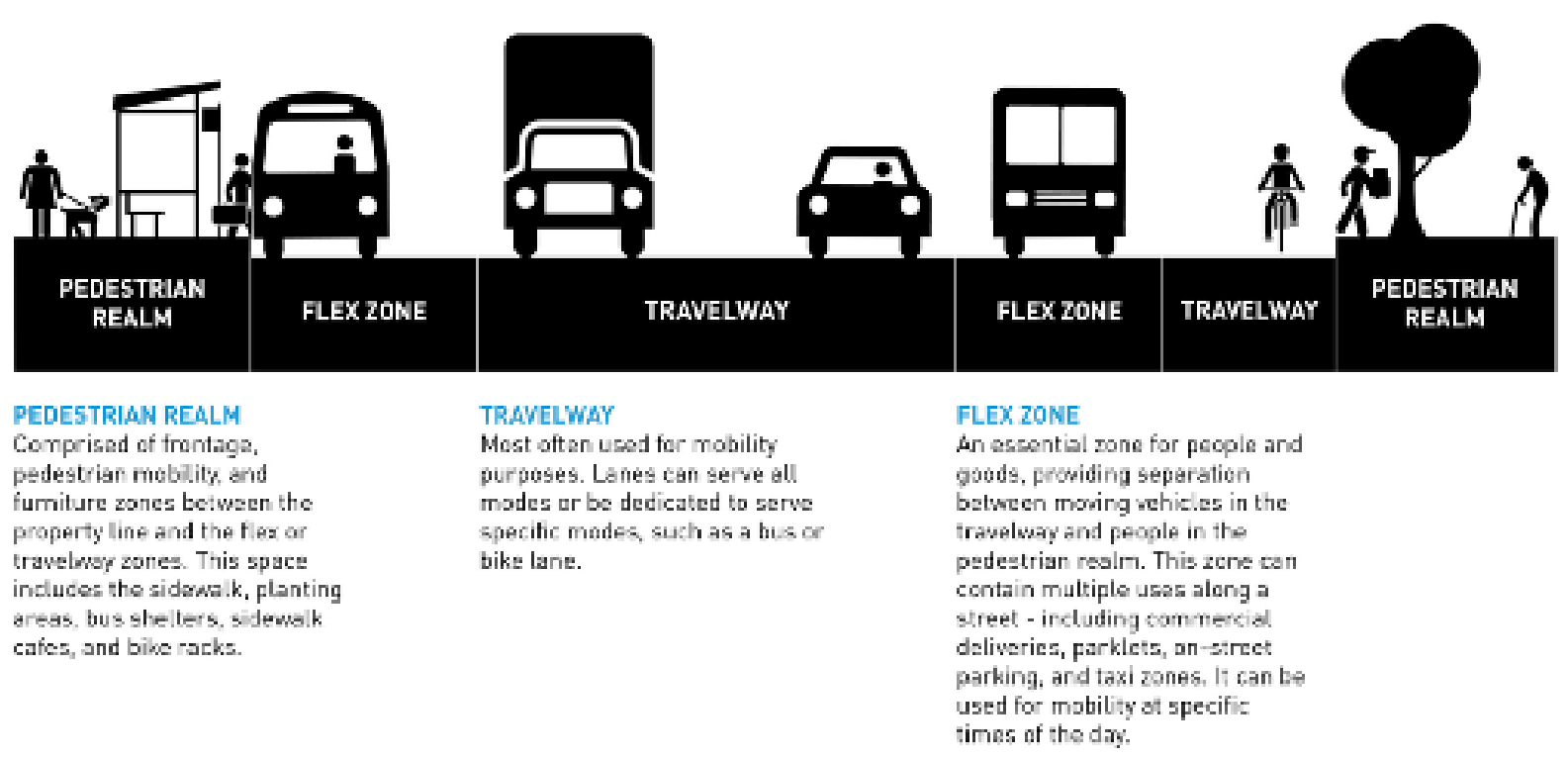

Source: Seattle Department of Transportation

The regulatory approach to managing the curb is in transition. Many jurisdictions understand that how curbs were managed in the past won't work in the future. One tool cities are using to better understand this change is by conducting pilot projects. The cities of Washington, D.C., New York, and others are actively working on curb management pilot projects.

This is an area of policy that continues to evolve; however, several cities have begun to think of overarching policies. Examples from plans include:

- City of Austin. The draft Austin Strategic Mobility Plan includes a section on curb management with three policies:

o "Policy 1: Use context to determine mobility and non-mobility curb uses. Identify the most appropriate uses for curbs by considering mobility, safety, street type, surrounding land use, and location.

o Policy 2: Manage curb space dynamically. Flexibly allocate curb space to adapt to different uses and users.

- Policy 3: Streamline objects at the curb to improve safety and mobility. Coordinate the placement, number, and use of objects at the curb with natural features to realize multiple community benefits." (City of Austin, n.d.).

- Denver region. The Denver Region Mobility Choice Blueprint's second objective is to integrate shared mobility. Tactical Action 2.4 is to implement curbside 
management standards "for passenger loading and freight delivery by developing policies and employing technologies to monitor, enforce, and monetize curbside operations." (Colorado Department of Transportation et al., 2018).

- City of Portland. TSP Policy 9.69.b is "Design and manage the mobility zone, Curb Zone, and traffic control devices to limit speeds to increase safety, to minimize cut-through traffic, evaluate future demand for pick-up and drop-off zones, and to prioritize automated electric vehicles carrying more passengers in congested times and locations." (City of Portland, Bureau of Transportation, 2018).

\subsubsection{Consider changes in land use and metropolitan footprint}

On the one hand, new mobility modes, especially $A V s$, have the potential to both increase the intensity of land uses in urban centers and corridors by reducing the demand for parking. On the other hand, new mobility, and especially AVs, could increase sprawl by reducing the friction of driving through decreasing cost and allowing passengers to do more pleasant and productive things other than drive. Government policy could help shape how much infill occurs on existing parking lots, and how much farm, forest, and rural land is consumed by sprawl.

It's hard to say exactly how much land is dedicated to parking, though there have been numerous estimates that range from 100 million to two billion parking spaces across the U.S. (Kimmelman, 2012). New mobility services are dependent on people not using their personally owned vehicles and parking them at their destination. This presents a significant opportunity to reclaim that space for more productive uses, from housing to employment to parks or open space. Cities should begin to plan for this opportunity and consider the steps that will aid the transition and ensure city codes do not continue to require developers to provide even more parking that likely will not be used in the future. There is additional work to do to convince banks and others that financing parking will be increasingly risky as the demand for parking goes down.

Cities may want to be thinking and planning now for how they can more productively use reclaimed parking spaces. On-street parking can be used for drop-off/pick-up zones, or for transit, bikes, e-scooters, and other micromobility uses. It can also be used for landscaping and to manage stormwater. When it comes time to consider what to do with off-street parking, cities will need to determine if the current zoning is adequate for the demand for that use, or if it should re-zone the land for other uses. It is likely that the areas with the greatest potential for redevelopment are in downtowns and corridors with high-capacity transit.

Some cities, like the City of Austin, considering changes to parking focus on on-street parking and how the ROW could evolve. The City of Chandler is one of the few places that has changed its zoning code to reduce minimum parking requirements, though it remains to be seen if this policy results in reduced off-street parking. Example policies are: 
- City of Austin. The draft Austin Strategic Mobility Plan parking policy 3 is "Coordinate on-street parking and curb management strategies for flexibility and adaptability with future parking and mobility technology." (City of Austin, n.d.).

- City of Chandler. To date, the City of Chandler is the only jurisdiction that has adopted minimum parking requirement reductions if a development includes loading zones for AVs. The objectives of the policy are to: "(1) Provide the City with more flexibility to reduce minimum parking requirements as parking demand changes, and, (2) Encourage developments to install passenger loading zones." (City of Chandler, 2018).

\subsubsection{Make informed decisions}

It's particularly true that it is difficult to manage what you don't measure, especially in relation to managing a city or regional transportation system. As new mobility services continue to disrupt how people and goods move across a region, decision makers must better understand those changes and model how movement will change in the future to make sure they can wisely invest millions (or billions) of dollars in transportation funds. New mobility companies and others are collecting movement data, but jurisdictions aren't likely to get that information from private companies unless they require it. Historically it has been difficult to get information from TNC companies and even when they do share data, it is sometimes protected from the public by non-disclosure agreements. Cities have been more successful requiring data of e-scooter companies. It remains to be seen if cities are successful in requiring data of all new mobility providers in the future.

The City of Los Angeles is a leader in this area and is striving to develop the idea of "Data as a Service." Data as a Service is the "...rapid exchange of real-time conditions and service information between service providers, customers and the supporting infrastructure. This requires a seamless data exchange with a variety of partners and stakeholders, privacy and security protections, the capacity to analyze data from a variety of resources, and the ability to integrate this insight into a data-driven decisionmaking process (as opposed to an anecdotal one) for both system managers and city leaders. Data sharing is a relatively cost-effective way to enhance connectivity and system efficiency without constructing new physical infrastructure. With better data, LADOT will be in a position to become more responsive to the transportation needs of Angelenos as both a service provider and regulator of transportation in Los Angeles." (Hand, 2016, p ii).

Los Angeles' data policy recommendations are:

1. Define what can be shared.

2. Adopt privacy principles.

3. Develop a standard data sharing agreement.

4. Create a regional blueprint for system integration.

5. Establish design guidelines for digital infrastructure. 
The City of Portland noted in its e-scooter report that not all companies defined terms in the same way, which resulted in underreported vehicles for one company. Given the rapidly evolving nature of both the technology as well as the learning curve, cities have multiple reasons to ensure the data they get from companies is accurate, from enforcing vehicle distribution to collection of fees. Standardization and experience will likely help improve compliance over time. The City of Portland joined with 15 other jurisdictions and six companies to create the Open Mobility Foundation (OMF) ${ }^{1}$. OMF's goal is to create a governance structure around open-source mobility tools, with a focus on mobility data specification.

\subsubsection{Manage innovation}

Changes in mobility have been happening so fast that it's been difficult for cities to keep up. Many new mobility companies have taken the "grenade launching" approach to the introduction of new services by putting them on the street without operating permits. Commercial e-scooter services, first introduced in Santa Monica, epitomize what can go wrong with a deployment. In an interview for Curbed, Rick Cole, Santa Monica's City Manager, characterized the initial deployment of e-scooters in 2017 as a "punishing experiment." He joked that when e-scooters were first introduced, "he spent a third of his time running the city, a third of his time answering emails from those who thought escooters represented the end of Western civilization, and a third of his time responding to Twitter posts that he was clamping down on the best invention since the iPhone one that would save the planet" (Sisson, 2018b).

While many cities have been caught without a permitting process for new mobility technologies, they are starting to catch up. That said, they are finding that many city procurement policies may not be the best way to provide services to citizens, given the rapidly evolving technological landscape.

Cities across the country are embracing the use of pilot projects to introduce new mobility services or try to manage mobility services in a small, controlled area. Examples in Oregon include the Portland E-Scooter Pilot project and Metro's Partnerships and Innovative Learning Opportunities in Transportation (PILOT) program. Pilot projects can be a cost-effective way to better understand how the technology operates, costs, its utility, and other intended and unintended consequences.

Most pilot projects include the following elements:

- Time frame. Pilot projects generally last from several months to one year.

- Limited number of vehicles. There are no set criteria for how many vehicles are the right number for a pilot project. Cities need to allow enough to be able to determine the potential impacts as well as provide adequate coverage for the city and for the companies, but not so many that they overwhelm the city. This could

\footnotetext{
${ }^{1}$ Accessed online at https://www.openmobilityfoundation.org/ on September 30, 2019.
} 
mean limiting the total number of vehicles per company, limiting the total number of vehicles, regardless of company, or gradually increasing the total number of vehicles over time.

- Enforcement. Cities should include a plan to monitor service provisions and budget for enforcement of permit requirements. This could mean ensuring that users are not going in restricted areas (like e-scooters on sidewalks) or that companies are placing vehicles in required locations.

- Outreach plan. While companies will have a marketing plan or strategy to let customers know about their service, cities need to develop an outreach plan to let residents know that a service is coming, educate them about the rules of the road, parking guidelines (for dockless e-scooters or bikes), and safety considerations for all services. In addition, some pilots include user surveys to understand who is using the service, the socio-economics of users, and their attitudes about the service.

- Industry partners. Cities will need to work with technology companies and industry partners to provide transportation services. Sometimes the partner is identified first, or the project is identified and companies competitively bid on the opportunity to provide the service. Different approaches may be required for different circumstances.

- Data sharing. All pilots should include data to understand the measurable outcomes of the pilot project. Data sharing should ensure protection of user privacy and proprietary company data.

- Evaluation. All pilots should include an evaluation stage to understand what happened and determine what changes the city would like to make before rolling out a larger pilot or an ongoing permit process.

- Budget. Finally, cities should consider the resources necessary to conduct a pilot project. Significant staff resources may be necessary, along with enforcement, outreach, surveys and other activities that must be paid for with limited funds. Some pilots charge a fee (such as a fee per ride) to help pay for the city cost of the pilot.

\subsubsection{Consider the fiscal impacts}

New mobility technologies are already disrupting how cities and other jurisdictions pay for transportation infrastructure as well as operations and maintenance. Some agencies are seeing a benefit from charging for TNC rides, such as the Los Angeles Airport that saw TNC revenues of $\$ 24.8$ million in 2017, offsetting a decrease in revenues of $\$ 3.4$ million from bus, limousine, and taxi services (Department of Airports, Los Angeles, CA, 2017). However, many other jurisdictions will need to plan for changes in revenue from parking and parking citations, vehicle registration, moving vehicle citations and, most significantly, reductions in the fuels tax. 
Most of the major car companies developing AVs are testing hybrid and electric vehicles. A 2017 article in the Verge reported that General Motors, Ford, Tesla, and Waymo have committed to creating AVs in hybrid or electric vehicles (Hawkins, 2017). One reason is that the electronics in AVs require significant battery power. The need for power increases as automation increases. In addition, car manufacturers are ramping up production of zero-emission vehicles to comply with California's GHG reduction targets. As more people and goods are transported in hybrid and electric vehicles, less money will be spent on fuel taxes. According to the Tax Policy Center, over $\$ 43.8$ billion in motor fuel tax revenue was collected in the United States in 2015, including $\$ 540$ million in Oregon. ${ }^{2}$ Fuel taxes are one of the primary sources of transportation funding. Cities will need to think about how they will replace funding for transportation infrastructure. Charging fees on new mobility services could potentially replace those funds.

Currently, some cities and other jurisdictions are charging a per-ride fee, a percent of the total fee, or a vehicle-per-day fee for new mobility services. While no city in the United States currently charges for congestion, Oregon is one of a few states that is piloting a road usage charge that has the potential to collect a per-mile fee. This may be another model for charging for the use of roads. Another option is to convert on-street parking to drop-off/pick-up pricing (especially for high-demand locations). Of course, there are many other ways to charge vehicles for traveling in the most congested locations at the most popular times, such as cordon pricing. Cities should consider a full suite of options to determine the methods that are best to achieve community goals.

Cities should make sure their policies include the right to charge new mobility companies a fee to operate in their city, whether or not they actually collect the fee or not.

Examples:

- City of Portland. The Transportation System Plan (2018) 9.68.b includes language to "ensure that connected and automated vehicles improve travel time reliability and system efficiency by...(3) paying for use of, and impact on, Portland's transportation system including factors such as congestion level, vehicle miles traveled, vehicle occupancy, and vehicle energy efficiency." (City of Portland, Bureau of Transportation, 2018).

- Denver Region. The Mobility Choice Blueprint identifies several tactical actions to help fund transportation infrastructure including exploring a road usage charge for the state of Colorado as well as supporting legislation to ensure that AVs generate funding from new user fees, registration fees, and other revenue streams to help fund the transportation system (Colorado Department of Transportation et al., 2018).

2 https://www.taxpolicycenter.org/statistics/motor-fuel-tax-revenue. Accessed 12/17/18. 
- City of Los Angeles. The City of Los Angeles envisions a suite of transportation financing options in its Urban Mobility in a Digital Age including charging by the mile, sales tax, public/private partnerships, infrastructure banks, different ownership models, and municipal bonds (Hand, 2016).

\subsection{GRESHAM AND EUGENE POLICY ASSESSMENT FOR NEW MOBILITY}

Now that we've discussed some of the first-level impacts and common policy topics and approaches taken around the country to address these impacts, the cities of Gresham and Eugene will need to decide what types of policies they will need to consider and adopt. This final section discusses the existing statewide conditions, as well as the unique attributes of each city, the policy plans to consider, and recommends next steps for each city.

\subsubsection{State of Oregon}

\subsubsection{New mobility regulations}

Oregon has few statewide policies or regulations specific to new mobility. Oregon is the only state that does not have statewide TNC regulations, though several bills were introduced in the 2019 Oregon Legislature and failed to pass. In the meantime, jurisdictions must negotiate on a city-by-city basis with TNC service providers. Cities that have adopted TNC regulations are Portland, Eugene, Medford, Salem, Ashland, Bend, and Redmond, among others. The state has virtually no regulations for micromobility (e-scooters or bikeshare) beyond the requirements to wear helmets and restrictions for riding e-scooters on sidewalks.

\subsubsection{Planning for autonomous vehicles}

The Oregon Department of Transportation's (ODOT) Office of Innovation is studying the impacts of autonomous and connected vehicles and released the Emerging Technology Impact Assessment Final Report in March 2019 (Jacobs, 2019). ODOT plans to engage stakeholders, including Area Commissions on Transportation (ACTs), Metropolitan Planning Organizations (MPOs), and peer state agencies next.

The Oregon Legislature created the Oregon Automated Vehicle Task Force ${ }^{3}$ with the passage of HB 4063 in the 2018 legislative session with the purpose of making recommendations on autonomous vehicles to the Legislature. The task force was created in May 2018 and its first report, completed in September 2018, focused on licensing and registration, law enforcement and crash reporting, cybersecurity, and insurance and liability. The task force plans to submit a second report to the Legislature in September 2019 focusing on land use, road and infrastructure design, public transit, workforce changes, and state responsibilities relating to cybersecurity and privacy.

\footnotetext{
$3 \quad$ Note that one of the authors of this report, Becky Steckler, is a member of the AV Task Force.
} 


\subsubsection{The gas tax and OreGo}

The University of Oregon and others have conducted research regarding the potential impact of autonomous vehicles on transportation revenues, especially the gas tax. Oregon has one of the longest running road usage charge pilot projects in the country OreGo. While the pilot project appears to have successfully considered many of the logistical challenges of charging drivers for vehicle miles traveled, the political will to do something with that information has stalled. That said, HB 2017, a transportation funding bill passed in the 2017 Oregon Legislative session, directed the Oregon Transportation Commission to develop a congestion pricing proposal.

\subsubsection{The City of Gresham}

\subsubsection{Regional Context}

The City of Gresham is located on the east side of the Portland metropolitan region. Located within Multnomah County and the Metro regional boundaries, it must comply with Metro's Regional Framework Plan, Urban Growth Management Functional Plan, and the Regional Transportation Plan as well as statewide policies. Metro has drafted an Emerging Technology Strategy that focuses on issues related to equity, choices, information, and innovation (Metro, 2018). The strategy also discusses the need to convene partners and establish new mobility policies that align with the strategy.

The City of Gresham currently has no operating regulations for new mobility services. TNCs operate without a permit, and there is no bikeshare program (docked or dockless) that requires regulations. During the 2018 Portland E-Scooter Pilot, Gresham ordered the e-scooter companies to remove any e-scooters that ended up in Gresham. The rationale for requesting e-scooter vendors to remove them was that Gresham was concerned about how the e-scooters would operate and the possibility they could impede access for people with disabilities or create unsafe conditions in the right-ofway. Because Gresham did not have guidelines or standards developed to address this issue, city officials requested removal of all e-scooters that ended up there.

\subsubsection{Policy Scan: Relevant goals, policies, and actions; opportunities, gaps, and recommendations}

The City of Gresham's long-range policies for transportation and land use currently include many supportive goals, objectives, strategies, and action items that should be considered when developing new mobility policies. Urbanism Next researchers conducted a preliminary scan of Gresham's plans, including the Transportation System Plan (2014), the Active Transportation Plan (2018), and the Comprehensive Plan. Table 4-3 shows the policies, actions, and implementation measures in the plans that are relevant to new mobility. These plans are generally supportive of safety, social equity, active transportation, reducing congestion and VMT, sustainability and environment, design and management of the ROW, and changes in land use and metropolitan footprint that should be incorporated into policies and regulations for new mobility services. As the city considers new mobility goals, policies, and actions, it should make sure that they are designed to achieve city goals. 
Table 4-3: City of Gresham scan of policies relevant for new mobility

\begin{tabular}{|c|c|c|c|}
\hline New Mobility & \multicolumn{3}{|c|}{ City of Gresham policies and Actions } \\
\hline \multirow[t]{7}{*}{ Safety } & $\begin{array}{l}\text { TSP: Transportation } \\
\text { System }\end{array}$ & $\begin{array}{l}\text { Policy 1, Action 1, } 4 \\
\text { Policy 2, Action } 5 \\
\text { Policy 4, Action 1, } 2\end{array}$ & \multirow{7}{*}{$\begin{array}{l}\text { The TSP policies related to safety } \\
\text { call for providing and promoting a } \\
\text { transportation system and options } \\
\text { that are safe, convenient, and } \\
\text { comfortable. Investments should } \\
\text { focus in part on pedestrian and } \\
\text { bicycle improvements that connect } \\
\text { to transit and schools. It calls for } \\
\text { investments in high-crash locations. } \\
\text { The ATP also calls for increasing } \\
\text { safety for walkers and bikers. The } \\
\text { Comprehensive Plan calls for using } \\
\text { design to reduce speeds and } \\
\text { crashes as well as ensuring the } \\
\text { street system supports healthy, } \\
\text { active living. }\end{array}$} \\
\hline & TSP: Street System & $\begin{array}{l}\text { Policy 1, Action 4, } 7 \\
\text { Policy 2, Action } 4 \\
\text { Policy 3, Action } 5 \\
\text { Policy 4, Action } 4 \\
\end{array}$ & \\
\hline & TSP: Transit System & Policy 4, Action 1, 2 & \\
\hline & $\begin{array}{l}\text { TSP: Pedestrian } \\
\text { System }\end{array}$ & Policy 1, all Actions, 1 & \\
\hline & ATP & Revised TSP Policy 1 & \\
\hline & $\begin{array}{l}\text { CP: Transportation } \\
\text { System }\end{array}$ & Policy 4, Action 1, 2 & \\
\hline & CP: Street System & $\begin{array}{l}\text { Policy 4, Action 3, 4, 5, } \\
6\end{array}$ & \\
\hline \multirow[t]{4}{*}{ Social Equity } & $\begin{array}{l}\text { TSP: Transportation } \\
\text { System }\end{array}$ & $\begin{array}{l}\text { Policy 1, Action } 2 \\
\text { Policy 2, Action } 5 \\
\end{array}$ & \multirow{4}{*}{$\begin{array}{l}\text { The TSP policies and actions focus } \\
\text { on responding to "all communities' } \\
\text { needs" including those identified by } \\
\text { residents. The TSP Transit policies } \\
\text { and actions include paratransit } \\
\text { service and addressing the needs of } \\
\text { the transit dependent such as the } \\
\text { elderly, low-income, and people with } \\
\text { disabilities. }\end{array}$} \\
\hline & TSP: Transit System & $\begin{array}{l}\text { Policy 2, Action } 1 \\
\text { Policy 3, Action } 3\end{array}$ & \\
\hline & TSP: TDM & Policy 1, Action 2 & \\
\hline & ATP & $\begin{array}{l}\text { Revised TSP Policy } 7 \\
8,9,10\end{array}$ & \\
\hline \multirow[t]{8}{*}{$\begin{array}{c}\text { Active } \\
\text { Transportation }\end{array}$} & $\begin{array}{l}\text { TSP: Transportation } \\
\text { System }\end{array}$ & $\begin{array}{l}\text { Policy 1, Action 1, 3, } \\
5,7 \\
\text { Policy 2, Action 2, } 4\end{array}$ & \multirow{8}{*}{$\begin{array}{l}\text { All of the plans identify policies and } \\
\text { activities to invest in, promote, and } \\
\text { otherwise make walking, biking, and } \\
\text { transit use safe, convenient, and } \\
\text { more accessible in almost all areas } \\
\text { of the city. }\end{array}$} \\
\hline & TSP: Street System & $\begin{array}{l}\text { Policy 1, Action 1, } 2, \\
3,4,5,7 \\
\text { Policy 2, Action 8, } 9 \\
\text { Policy 3, Action 2, } 6 \\
\text { Policy 4, Action 4 }\end{array}$ & \\
\hline & TSP: Transit System & $\begin{array}{l}\text { Policy 2, Action } 1 \\
\text { Policy } 3, \text { Action 4, 6, } 7\end{array}$ & \\
\hline & $\begin{array}{l}\text { TSP: Bicycle } \\
\text { Network }\end{array}$ & $\begin{array}{l}\text { Policy } 1, \text { all Actions } \\
\text { Policy } 2 \text {, all Actions, } 1\end{array}$ & \\
\hline & $\begin{array}{l}\text { TSP: Pedestrian } \\
\text { system }\end{array}$ & $\begin{array}{l}\text { Policies 1, 2, 3, all } \\
\text { Actions }\end{array}$ & \\
\hline & TSP: TDM & Policy 1, Action 1, 3 & \\
\hline & ATP & $\begin{array}{l}\text { All revised TSP } \\
\text { Policies, p } 18 .\end{array}$ & \\
\hline & $\begin{array}{l}\text { CP: Downtown Plan } \\
\text { Dist }\end{array}$ & $\begin{array}{l}\text { Urban Design Policy } 8 \\
\text { Transp \& Con Policy } \\
\text { 1, 2; Action } 1\end{array}$ & \\
\hline
\end{tabular}




\begin{tabular}{|c|c|c|c|}
\hline \multirow{7}{*}{$\begin{array}{l}\text { New Mobility } \\
\text { Policy Topics }\end{array}$} & \multicolumn{3}{|c|}{ City of Gresham policies and Actions } \\
\hline & $\begin{array}{l}\text { CP: Transportation } \\
\text { System }\end{array}$ & Policy 1, all Actions & \\
\hline & CP: Street System & $\begin{array}{l}\text { Policy 1, all Actions } \\
\text { Policy 2, Actions 1, } 2\end{array}$ & \\
\hline & CP: Transit & $\begin{array}{l}\text { All Policies and } \\
\text { Actions }\end{array}$ & \\
\hline & CP: Bicycle System & $\begin{array}{l}\text { All Policies and } \\
\text { Actions }\end{array}$ & \\
\hline & $\begin{array}{l}\text { CP: Pedestrian } \\
\text { System }\end{array}$ & $\begin{array}{l}\text { All Policies and } \\
\text { Actions }\end{array}$ & \\
\hline & $\begin{array}{l}\text { CP: Community } \\
\text { Health and the Built } \\
\text { Environment }\end{array}$ & $\begin{array}{l}\text { All Policies and } \\
\text { Actions }\end{array}$ & \\
\hline \multirow{7}{*}{$\begin{array}{l}\text { Congestion } \\
\text { and vehicle } \\
\text { miles traveled }\end{array}$} & $\begin{array}{l}\text { TSP: Transportation } \\
\text { System }\end{array}$ & $\begin{array}{l}\text { Policy 1, Action 4, 5, } \\
7,8\end{array}$ & \multirow{7}{*}{$\begin{array}{l}\text { The TSP identifies policies and } \\
\text { actions to reduce automobile } \\
\text { dependence through support and } \\
\text { investment in other modes. The } \\
\text { TDM policies and actions in the TSP } \\
\text { and the Comprehensive Plan are } \\
\text { designed to reduce congestion and } \\
\text { VMT. Regarding freight, the TSP } \\
\text { identifies the need to design streets } \\
\text { to provide for efficient and safe } \\
\text { movements of trucks. }\end{array}$} \\
\hline & TSP: Street System & $\begin{array}{l}\text { Policy 2, Action } 5 \\
\text { Policy 3, Action } 2\end{array}$ & \\
\hline & TSP: Transit System & Policy 1, Action 3 & \\
\hline & TSP: TDM & Policy 1, Action 1 & \\
\hline & $\begin{array}{l}\text { TSP: Truck and } \\
\text { Freight System }\end{array}$ & Action 1,2 & \\
\hline & $\begin{array}{l}\text { CP: Transportation } \\
\text { System }\end{array}$ & Policy 2, Action 6 & \\
\hline & CP: TDM & $\begin{array}{l}\text { All Policies and } \\
\text { Actions }\end{array}$ & \\
\hline \multirow{8}{*}{$\begin{array}{l}\text { Sustainability } \\
\text { and the } \\
\text { environment }\end{array}$} & $\begin{array}{l}\text { TSP: Transportation } \\
\text { System }\end{array}$ & $\begin{array}{l}\text { Policy } 1 \text {, Action } 6 \\
\text { Policy } 2 \text {, Action } 3,7\end{array}$ & \multirow{8}{*}{$\begin{array}{l}\text { The TSP calls for protecting natural } \\
\text { resources, improving air and water } \\
\text { quality, promoting energy-efficient or } \\
\text { low- and zero-emissions vehicles } \\
\text { and bicycling, transit, and pedestrian } \\
\text { modes. The only action directly } \\
\text { related to GHG emission reductions } \\
\text { is TSP: TDM Policy } 1 \text {, Action 10: } \\
\text { "Support state and regional } \\
\text { programs aimed at reducing } \\
\text { greenhouse gases and other harmful } \\
\text { emissions." }\end{array}$} \\
\hline & TSP: Street System & Policy 4, Action 1 & \\
\hline & TSP: Transit System & Policy 1, Action 3 & \\
\hline & TSP: TDM & Policy 1, Action 10 & \\
\hline & CP: Air Quality & $\begin{array}{l}\text { Policy } 3,4 \\
\text { Action } 3,7\end{array}$ & \\
\hline & CP: Water Quality & Policy 6 & \\
\hline & $\begin{array}{l}\text { CP: Transportation } \\
\text { System }\end{array}$ & Policy 2, Action 7 & \\
\hline & CP: Street System & Policy 4, Action 1 & \\
\hline \multirow{6}{*}{$\begin{array}{l}\text { Design and } \\
\text { management } \\
\text { of the right-of- } \\
\text { way }\end{array}$} & $\begin{array}{l}\text { TSP: Transportation } \\
\text { System }\end{array}$ & Policy 2, Action 1, 2 & \multirow{6}{*}{$\begin{array}{l}\text { Most of the policies and actions in } \\
\text { these sections refer to multi-modal } \\
\text { street design and ensuring an } \\
\text { "efficient" transportation system that } \\
\text { takes advantage of the existing } \\
\text { capacity and makes it more efficient. }\end{array}$} \\
\hline & TSP: Street System & $\begin{array}{l}\text { Policy 2, Action } 5 \\
\text { Policy 4, Action } 4 \\
\end{array}$ & \\
\hline & TSP: Transit System & Policy 3, Action 3, 10 & \\
\hline & $\begin{array}{l}\text { TSP: Truck and } \\
\text { Freight System }\end{array}$ & Policy 1, Action 1 & \\
\hline & $\begin{array}{l}\text { CP: Comm Design, } \\
\text { Trees and Veg }\end{array}$ & $\begin{array}{l}\text { Policy } 1,11 \\
\text { Action } 9,10\end{array}$ & \\
\hline & $\begin{array}{l}\text { CP: Downtown Plan } \\
\text { Dist }\end{array}$ & Urban Design Action 4 & \\
\hline
\end{tabular}




\begin{tabular}{|c|c|c|c|}
\hline \multirow{3}{*}{$\begin{array}{l}\text { New Mobility } \\
\text { Policy Topics }\end{array}$} & \multicolumn{3}{|c|}{ City of Gresham policies and Actions } \\
\hline & $\begin{array}{l}\text { CP: Transportation } \\
\text { System }\end{array}$ & Policy 2, Actions 1, 2 & \\
\hline & CP: Street System & $\begin{array}{l}\text { Policy 2, Action 5, 7, } 8 \\
\text { Policy 3, Actions 3, } 4\end{array}$ & \\
\hline \multirow{5}{*}{$\begin{array}{l}\text { Changes in } \\
\text { land use and } \\
\text { metropolitan } \\
\text { footprint }\end{array}$} & TSP: Transit System & $\begin{array}{l}\text { Policy 3, Action 5, 8, } \\
9,10\end{array}$ & \multirow{5}{*}{$\begin{array}{l}\text { Most of the policies, actions, and } \\
\text { implementation items identified here } \\
\text { are for densities of housing and jobs } \\
\text { that support transit and the efficient } \\
\text { development of land, especially in } \\
\text { downtown and other residential and } \\
\text { employment districts. }\end{array}$} \\
\hline & $\begin{array}{l}\text { CP: Commercial } \\
\text { Land Use }\end{array}$ & $\begin{array}{l}\text { Policy 1, } \\
\text { Implementation } 2 \\
\text { Policy 2, } \\
\text { Implementation 1, } 3 \\
\end{array}$ & \\
\hline & $\begin{array}{l}\text { CP: Industrial Land } \\
\text { Use }\end{array}$ & Action $9,11,14$ & \\
\hline & $\begin{array}{l}\text { CP: Downtown Plan } \\
\text { District }\end{array}$ & $\begin{array}{l}\text { Trans \& Connection } \\
\text { Policy 6; Action } 2 \\
\text { Parks \& People Policy } \\
1 \\
\text { Economic } \\
\text { Development Policy } 4 \\
\text { Downtown Housing } \\
\text { Policy } 1,6 \\
\end{array}$ & \\
\hline & CP: Street System & Policy 3, Action 1 & \\
\hline $\begin{array}{l}\text { Informed } \\
\text { decision } \\
\text { making }\end{array}$ & $\begin{array}{l}\text { TSP: Transportation } \\
\text { System }\end{array}$ & Policy 4, Action 2 & $\begin{array}{l}\text { This action is to "monitor high crash } \\
\text { locations and types and develop } \\
\text { appropriate programs and projects to } \\
\text { address problems." }\end{array}$ \\
\hline \multirow[t]{6}{*}{$\begin{array}{l}\text { Managing } \\
\text { innovation }\end{array}$} & $\begin{array}{l}\text { TSP: Transportation } \\
\text { System }\end{array}$ & Policy 2, Action 5 & \multirow{6}{*}{$\begin{array}{l}\text { The TSP identifies the need to } \\
\text { "identify creative, non-traditional } \\
\text { funding" for transportation, as well as } \\
\text { maintaining "the City's flexibility to } \\
\text { take advantage of new funding } \\
\text { opportunities, including public/private } \\
\text { partnerships." Other policies } \\
\text { highlight working with jurisdictions } \\
\text { and TriMet to come up with } \\
\text { strategies to increase access to } \\
\text { transportation. }\end{array}$} \\
\hline & TSP: Transit System & $\begin{array}{l}\text { Policy 1, Action } 2 \\
\text { Policy 1, Action } 7 \\
\text { Policy 2, Action } 1\end{array}$ & \\
\hline & TSP: TDM & Policy 1, Action 1, 6, 7 & \\
\hline & CP: Land Use & Policy 13 & \\
\hline & $\begin{array}{l}\text { CP: Transportation } \\
\text { System } \\
\text { Management } \\
\text { Operations / } \\
\text { Intelligent } \\
\text { Transportation } \\
\text { Systems } \\
\end{array}$ & Policy and all Actions & \\
\hline & $\begin{array}{l}\text { CP: Political } \\
\text { Environment }\end{array}$ & $\begin{array}{l}\text { Policy and all } \\
\text { Implementation } \\
\text { Strategies }\end{array}$ & \\
\hline \multirow{3}{*}{$\begin{array}{l}\text { Fiscal impacts } \\
\text { and new } \\
\text { mobility } \\
\text { revenue }\end{array}$} & $\begin{array}{l}\text { TSP: Transportation } \\
\text { System }\end{array}$ & Policy 2, Action 5 & \multirow{3}{*}{$\begin{array}{l}\text { This policy and action item is to } \\
\text { create a Transportation Finance } \\
\text { Plan to pay for transportation in } \\
\text { Gresham. }\end{array}$} \\
\hline & CP: Land Use & Action 7 & \\
\hline & $\begin{array}{l}\text { CP: Transportation } \\
\text { System }\end{array}$ & Policy 2, Action 5 & \\
\hline
\end{tabular}

In addition, there are a number of opportunities to expand some specific city policies to address new mobility issues. These are: 


\section{Active Transportation: Mobility Hubs}

- Opportunity: TSP: Transit System, Policy 3, Action 7 states the City will "Work with TriMet to provide secure and convenient bicycle parking at light rail station and transit centers..."

- Recommendation: The City may want to consider working with TriMet to develop multimodal mobility hubs similar to Seattle and other jurisdictions that include bikes, e-scooters, and other modes to ease the transition from one mode to the next.

\section{Active Transportation: Conflict between modes}

- Opportunity: TSP: Bicycle Network, Policy 2, Action 1 directly supports the need for new mobility services to prioritize active transportation and reduce potential conflicts.

- Recommendation: The City of Gresham could consider adopting a policy that prioritizes funding for walking, biking, transit, microtransit, and electric modes over conventional gas single- or zero-occupancy modes of travel.

\section{Active Transportation: Conflict between modes}

- Opportunity: TSP: Pedestrian System, Policy 1, Action 1 guides Gresham to "design and build sidewalks...free of hazards..." directs the City to ensure sidewalks are unobstructed.

- Recommendation: This policy language could be expanded to also support new mobility policies which ensure that parked or moving dockless vehicles (like escooters) do not obstruct or impede pedestrians.

Design and Management of the Right-of-Way: Street design for new technologies

- Opportunity: CP: Street System, Policy 4, Action 6 calls for the City of Gresham to consider national guidelines for streets.

- Recommendation: NACTO created guidance for street design for AVs in their publication, Blueprint for an Autonomous Future (2018). The City may want to consider including references to national guidance from this document and other new mobility and AV guides as they are developed.

\section{Informed Decision Making: Requiring information}

- Opportunity: CP: Transportation System Management Operations/Intelligent Transportation Systems policy is, "(i)mplement transportation system management operations and intelligent transportation systems programs and strategies that reduce the need for single-occupant vehicle (SOV) travel and make walking, bicycling and taking transit more convenient for all trips to and 
within Gresham." The City identified technology as one way to gather information and craft strategies to reduce SOVs.

- Recommendation: This policy is directly applicable to new mobility policies and could be the basis for the City to consider information requirements from the new mobility companies as well as explore opportunities to coordinate with Metro, TriMet, and other public agencies on data collection and analysis to reduce single- and zero-occupancy vehicles, increase active transportation modes, and eventually manage the transportation system based on current, real-time conditions. The City should consider how the data can be used to inform City policies and programs, as well as explore opportunities to share real-time data with the public so they can make informed transportation choices.

The most significant policy gaps that are not identified in existing plans that the City could consider are:

\section{Social Equity}

- Gap: While the City has numerous goals, policies, and action items related to providing transportation access to communities of concern, there is no specific guidance for access in specific neighborhoods or across the city, payment options for the unbanked, equitable workforce policies, or accommodating people with disabilities.

- Recommendation: Determine if the City wants to create policies that specifically address equity, and if so (1) identify the geography (specific neighborhoods or the entire city) to focus on for either pilot projects or for deployment of services; (2) determine if the City wants to require new mobility providers to provide nonsmart phone/credit card options for payment; (3) determine if the City will require equitable workforce policies (for example, related to contractors that provide services to companies), and accommodating people with disabilities. Given rapidly changing socio-economic trends, the City should develop flexible policies or revisit them regularly to ensure they continue to address the needs of communities of concern.

\section{Sustainability and Environment}

- Gap: The City does not have explicit sustainability or environmental policies related to new mobility services, specifically the reduction of GHG emissions.

- Recommendation: Even absent a Climate Action Plan, the City of Gresham adopted numerous policies and action items that could result in lower GHG emissions, such as promoting low-carbon modes like walking, biking, and transit; reducing dependence on vehicles; and encouraging compact development close to transit. The City could also consider how these activities could reduce air pollution from vehicles. Finally, the City could take advantage of the opportunities presented by the potential to decrease parking and consider strategies and 
activities that result in a reduction of on-street parking and improve water quality through stormwater management.

\section{Design and management of the right-of-way}

- Gap: The City does not have any regulations related to management of new mobility in the right-of-way, specifically the curb and sidewalk.

- Recommendation: New mobility impacts suggest that the City will need to take a new approach to managing the ROW and especially the curb, specifically in high-demand locations like downtown and MAX stations. The City will need to understand changes in demand for the curb for both passengers and freight and goods delivery. The City should prepare residents and adjacent property owners that changes are likely and work with them, as well as continue to monitor promising practices from across the country, to prepare policies that improve the throughput of people and goods.

\section{Changes in land use and metropolitan footprint}

- Gap: The City of Gresham's policies assume that driving a personally owned vehicle will be the primary mode of movement in the City.

- Recommendation: If new mobility does reduce reliance on personally owned vehicles, then this assumption would need to be updated in transportation and land use plans. The City may need to reevaluate the amount of land zoned for residential, retail, office, and commercial, as well as industrial land to determine if the supply of land is adequate for the demand (especially if much more of the land is available for development instead of parking). The City may want to consider focusing redevelopment and development of parking lots in key districts/neighborhoods and along high-capacity transit routes. In addition, the City should closely monitor e-commerce and experiential retail trends to determine if it needs to re-evaluate the demand for commercial and retail land in the next update of its Comprehensive Plan.

\section{Informed decision making}

- Gap: The City of Gresham currently has no goals, policies, or action measures directly related to the collection of data or information from new mobility providers. This information would help the City better understand how the transportation system is being used, as well as how safe the services are, if they are providing affordable services to all Gresham residents, impacts on active transportation, demand for the curb, and other issues. This information is also critical for enforcement of requirements and fees (if applied).

- Recommendation: The City of Gresham should review the Los Angeles Data Mobility Specifications and work with regional partners (as well as the City of Portland, which has adapted this standard to collect data from e-scooter companies) to adopt a data standard for the City. 


\section{Managing innovation}

Gap: While the City of Gresham has formal relationships with regional partners (TriMet, Metro, and surrounding jurisdictions), coordination on new mobility services is still evolving.

- Many larger cities where new mobility deployments are happening first are trying to better manage impacts by conducting pilot projects. The City of Gresham does not have a pilot project process.

- Recommendation: Gresham's plans reference the coordination between its policies and regional and state policies, as well as activities to coordinate those activities. Gresham and regional leaders have an opportunity to coordinate more closely and formally on the collection and analysis of data, coordination on policies regulating new mobility providers, as well as coordination and payment standards for new mobility services.

It is unclear if there will be enough demand for pilot projects in Gresham, but if there is, the City may want to consider creating a pilot project framework. That said, the City may want to initiate pilot projects to better understand new mobility services. It may be appropriate to recruit companies for public/private partnerships to test these services.

\section{Fiscal impacts and new mobility revenue}

- Gap: Gresham has no adopted policies that specifically require that new mobility services fund transportation infrastructure and its impact on the transportation system.

- Recommendation: The City should evaluate different fee options to create a funding mechanism that helps the City achieve its goals, including paying city costs for managing new mobility (permitting, enforcement, evaluation, etc.), paying for the impact on transportation infrastructure and the transportation system, and investments that increase capacity and throughput of people and goods.

\subsubsection{City of Eugene}

\subsubsection{Regional context}

The City of Eugene is located in the Southern Willamette Valley and is the regional center, surrounded by Springfield, Coburg, Veneta, Cottage Grove and other smaller cities. Located within Lane County and a member of the Lane Council of Governments, it actively coordinates with the surrounding jurisdictions and the Lane Transit District on the Regional Transportation Plan and other policy documents. 
Two new mobility services are available in Eugene: transportation network companies and bikeshare. Uber first started operations in Eugene in 2014, but was forced to stop operations in April 2015 when the city ruled that it must secure a vehicle-for-hire license to continue operations (Hill, 2018). It took until September 2018 for Uber to get back on city streets. Lyft also operates in Eugene. The City of Eugene adopted revised regulations for the operation of TNCs and other public passenger vehicles in the city. Eugene introduced a docked bikeshare system - PeaceHealth Rides - in 2018. Figure 4-6 is a map of bikeshare stations in Eugene

Figure 4-6: Eugene bikeshare map, 2019

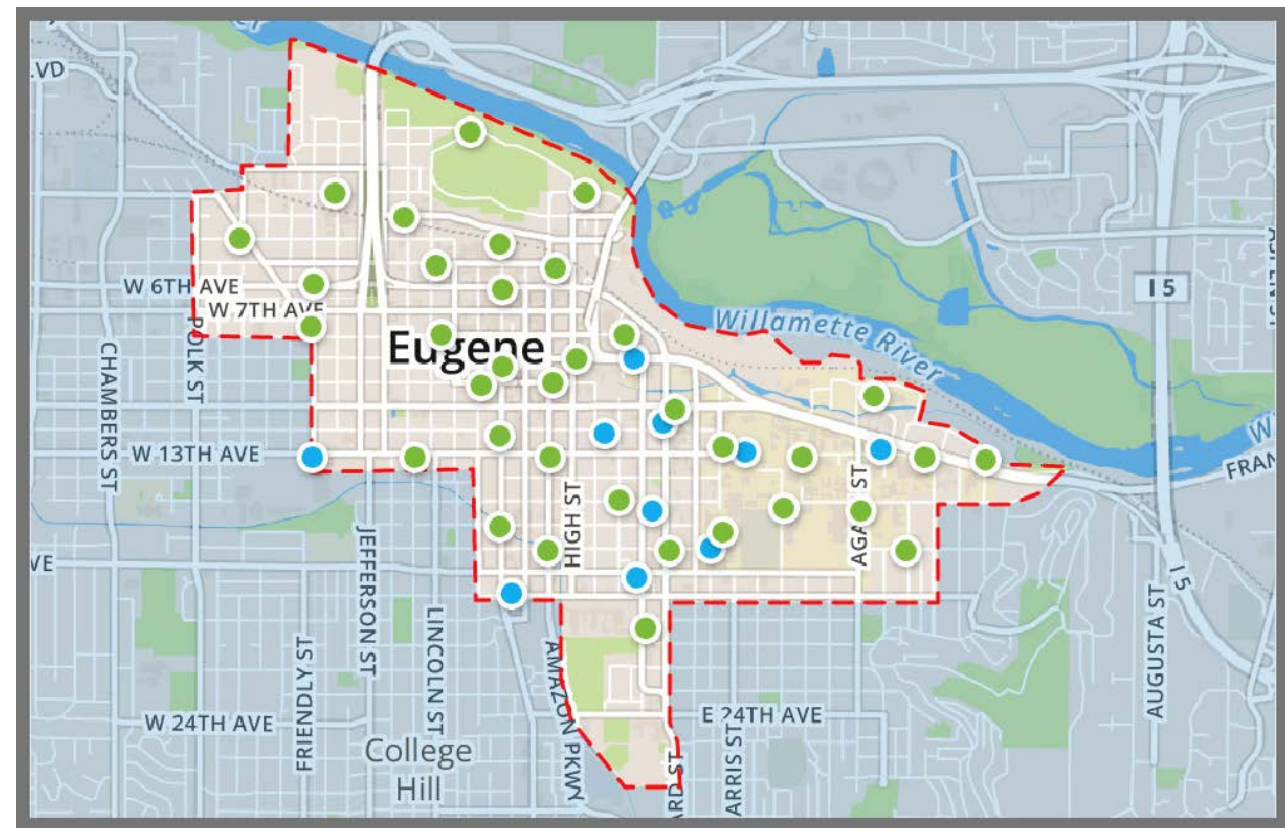

Source: PeaceHealth Rides (screenshot from: https://www.peacehealthrides.com/). Note that green dots are bikeshare stations and blue dots are bikes that are not at stations.

\subsubsection{Policy scan: relevant goals, policies, and actions; opportunities, gaps, and recommendations}

Eugene has a number of long-term plans which contain goals, policies, guidelines, and action items that shape ways transportation services serve and interact with the city. Many of these policies already provide useful guidance on how new mobility services can be incorporated into existing service frameworks, but there are also policies which will need to be changed or updated to ensure they continue to meet the community's goals in the future. Urbanism Next researchers identified the following plans that will likely be impacted by the introduction of new mobility services, or could be used to influence policies to allow these services in Eugene: 
Transportation policies:

- Eugene 2035 Transportation System Plan (2017)

- Eugene Vision Zero Action Plan (2019)

- MoveEUG: Eugene's Active Transportation Strategy (2017-2021)

- Envision Eugene Comprehensive Plan (2017)

- DRAFT Community Design Handbook (2017)

Environmental policies:

- A Community Climate and Energy Action Plan for Eugene (2010). Note that the City of Eugene is currently updating its Climate Action Plan.

Economic policies:

- Regional Prosperity Economic Development Plan: Eugene, Springfield, Lane County (2010)

These plans articulate goals to improve safety and equity; support and promote active transportation; and reduce congestion, vehicle miles traveled, and GHG emissions. The City of Eugene drafted an Urban Design Handbook and has a vision for the urban design of streets that are focused on people, not cars. Any new mobility plans, strategies, and actions the City of Eugene adopts should support these community goals.

Table 4-4 summarizes an initial scan of these plans to help highlight current policies and action items that new mobility policies should support. 
Table 4-4: City of Eugene scan of policies relevant for new mobility

\begin{tabular}{|c|c|c|c|}
\hline New Mobility & \multicolumn{3}{|c|}{ City of Eugene Policies and Actions } \\
\hline \multirow[t]{16}{*}{ Safety } & $\begin{array}{l}\text { TSP: Transportation } \\
\text { System }\end{array}$ & $\begin{array}{l}\text { System-Wide Policy } 2 \\
\text { System-Wide Potential } \\
\text { Actions E, F, G, K, P, } \\
\text { S, W }\end{array}$ & \multirow{16}{*}{$\begin{array}{l}\text { Eugene's policies relating to } \\
\text { safety are shaped by the City's } \\
\text { adoption of the Vision Zero } \\
\text { program, which strives to reduce } \\
\text { injuries and eliminate deaths } \\
\text { due to crashes. While the plan is } \\
\text { designed to protect and promote } \\
\text { safe walking and bicycling, these } \\
\text { modes are not explicitly } \\
\text { prioritized over automobiles in } \\
\text { the policy language. Potential } \\
\text { Action F within the 'Roadway } \\
\text { and Parking Policies' section of } \\
\text { the TSP does note that "plans } \\
\text { that state a preference for a } \\
\text { mode of travel in a specific } \\
\text { location" are "integral parts of } \\
\text { the planning, design, and } \\
\text { programming for public streets } \\
\text { and rights-of-way" and notes } \\
\text { bicycles as an example of a } \\
\text { designated mode, but does not } \\
\text { apply this modal preference } \\
\text { within policy language. }\end{array}$} \\
\hline & TSP: Transit Policies & $\begin{array}{l}\text { Potential Action A, } \\
\text { Item } 5 \\
\text { Potential Action C }\end{array}$ & \\
\hline & $\begin{array}{l}\text { TSP: Roadway and } \\
\text { Parking Policies }\end{array}$ & $\begin{array}{l}\text { Action B } \\
\text { Potential Actions F, K, } \\
\text { M }\end{array}$ & \\
\hline & $\begin{array}{l}\text { TSP: Pedestrian } \\
\text { Policies }\end{array}$ & $\begin{array}{l}\text { Policy } 2 \\
\text { Potential Action B, C }\end{array}$ & \\
\hline & TSP: Bicycle Policies & Policy 2,3 & \\
\hline & $\begin{array}{l}\text { TSP: Rail, Freight, and } \\
\text { Pipeline Policies }\end{array}$ & $\begin{array}{l}\text { Policy } 1,5,7 \\
\text { Potential Action G }\end{array}$ & \\
\hline & VZ: Strategies & All Strategies & \\
\hline & VZ: Street Design & $\begin{array}{l}\text { All Two-year Actions } \\
\text { All Five-year Actions }\end{array}$ & \\
\hline & VZ: Impairment & 2nd Two-year Action & \\
\hline & $\begin{array}{l}\text { VZ: Dangerous } \\
\text { Behaviors }\end{array}$ & All Two-year Actions & \\
\hline & $\begin{array}{l}\text { ATS: Action } 1 \text { - } \\
\text { Education }\end{array}$ & $\begin{array}{l}\text { Actions 1.1-1.4, 1.6- } \\
1.7,1.10\end{array}$ & \\
\hline & $\begin{array}{l}\text { ATS: Action } 2 \text { - } \\
\text { Encouragement }\end{array}$ & $\begin{array}{l}\text { Actions } 2.1,2.3,2.7 \text {, } \\
2.9\end{array}$ & \\
\hline & $\begin{array}{l}\text { ATS: Action } 3 \text { - } \\
\text { Enforcement }\end{array}$ & $\begin{array}{l}\text { Actions 3.1-3.4, 3.6, } \\
3.8-3.11\end{array}$ & \\
\hline & $\begin{array}{l}\text { ATS: Action } 4 \text { - } \\
\text { Engineering }\end{array}$ & $\begin{array}{l}\text { Actions } 4.1,4.4,4.6 \text {, } \\
4.12-4.18\end{array}$ & \\
\hline & $\begin{array}{l}\text { ATS: Action } 5 \text { - } \\
\text { Evaluation \& Planning }\end{array}$ & Actions 5.3-5.6, 5.7 & \\
\hline & $\begin{array}{l}\text { CDH: Create a } \\
\text { Network of Complete } \\
\text { Streets }\end{array}$ & Guidelines 5-8 & \\
\hline \multirow[t]{8}{*}{ Social equity } & $\begin{array}{l}\text { TSP: Transportation } \\
\text { System }\end{array}$ & $\begin{array}{l}\text { System-Wide Potential } \\
\text { Actions I, Q }\end{array}$ & \multirow{8}{*}{$\begin{array}{l}\text { The City's TSP features a } \\
\text { section entitled Equity, } \\
\text { Economy, and Community } \\
\text { Engagement Practices that } \\
\text { addresses many aspects of } \\
\text { social equity in transportation } \\
\text { planning. Other TSP sections } \\
\text { address ADA requirements, } \\
\text { community engagement } \\
\text { practices, and the creation of } \\
\text { context sensitive solutions, while } \\
\text { other documents discuss age- } \\
\text { based transportation needs and } \\
\text { the need for fair economies. }\end{array}$} \\
\hline & TSP: Transit Policies & $\begin{array}{l}\text { Policy } 3 \\
\text { Potential Action A, } \\
\text { Item } 3\end{array}$ & \\
\hline & $\begin{array}{l}\text { TSP: Roadway and } \\
\text { Parking Policies }\end{array}$ & Potential Actions F, L & \\
\hline & $\begin{array}{l}\text { TSP: Equity, } \\
\text { Economy, and } \\
\text { Community } \\
\text { Engagement Policies }\end{array}$ & $\begin{array}{l}\text { All Policies and } \\
\text { Potential Actions }\end{array}$ & \\
\hline & VZ: Street Design & 7th Two-year Action & \\
\hline & $\begin{array}{l}\text { VZ: Dangerous } \\
\text { Behaviors }\end{array}$ & 3rd Five-year Action & \\
\hline & $\begin{array}{l}\text { ATS: Action } 1 \text { - } \\
\text { Education }\end{array}$ & Actions $1.5,1.9$ & \\
\hline & $\begin{array}{l}\text { ATS: Action } 2 \text { - } \\
\text { Encouragement }\end{array}$ & Actions 2.9-2.11 & \\
\hline
\end{tabular}




\begin{tabular}{|c|c|c|c|}
\hline \multirow{6}{*}{$\begin{array}{l}\text { New Mobility } \\
\text { Policy Topics }\end{array}$} & \multicolumn{3}{|c|}{ City of Eugene Policies and Actions } \\
\hline & $\begin{array}{l}\text { ATS: Action } 3 \text { - } \\
\text { Enforcement }\end{array}$ & Action 3.7 & \\
\hline & $\begin{array}{l}\text { ATS: Action } 4 \text { - } \\
\text { Engineering }\end{array}$ & Actions $4.8,4.12$ & \\
\hline & $\begin{array}{l}\text { ATS: Action } 5 \text { - } \\
\text { Evaluation \& Planning }\end{array}$ & Actions $5.4-5.5,5.8$ & \\
\hline & $\begin{array}{l}\text { CDH: Create a } \\
\text { Network of Complete } \\
\text { Streets }\end{array}$ & Guideline 7 & \\
\hline & EDP: Strategy 2 & Tactic 2.5 & \\
\hline \multirow[t]{17}{*}{$\begin{array}{l}\text { Active } \\
\text { transportation }\end{array}$} & $\begin{array}{l}\text { TSP: Transportation } \\
\text { System }\end{array}$ & $\begin{array}{l}\text { System-Wide Policies } \\
1,3,4 \\
\text { System-Wide Potential } \\
\text { Actions B, C, E, K, M, } \\
\mathrm{O}, \mathrm{Q}\end{array}$ & \multirow{17}{*}{$\begin{array}{l}\text { Eugene had a robust selection } \\
\text { of active transportation polices, } \\
\text { actions, and guidelines. } \\
\text { Supporting pedestrian and } \\
\text { cyclist activity is an integral part } \\
\text { of the City's TSP and Vision } \\
\text { Zero programs and is the basis } \\
\text { for MoveEUG: Eugene's Active } \\
\text { Transportation Strategy. Support } \\
\text { for active transportation is also } \\
\text { found in the City's Community } \\
\text { Design Handbook and } \\
\text { Community Climate and Energy } \\
\text { Action Plan for Eugene, where } \\
\text { walking and biking are } \\
\text { recognized as key components } \\
\text { in healthy, livable, low-carbon } \\
\text { communities. }\end{array}$} \\
\hline & TSP: Transit Policies & $\begin{array}{l}\text { Policy } 1 \\
\text { Potential Action A, } \\
\text { Item } 5 \\
\text { Potential Action C }\end{array}$ & \\
\hline & $\begin{array}{l}\text { TSP: Roadway and } \\
\text { Parking Policies }\end{array}$ & $\begin{array}{l}\text { Potential Actions B, F, } \\
\mathrm{K}, \mathrm{L}, \mathrm{S}\end{array}$ & \\
\hline & $\begin{array}{l}\text { TSP: Pedestrian } \\
\text { Policies }\end{array}$ & $\begin{array}{l}\text { Policies 1, } 2 \\
\text { All Potential Actions }\end{array}$ & \\
\hline & TSP: Bicycle Policies & $\begin{array}{l}\text { All Policies and } \\
\text { Potential Actions }\end{array}$ & \\
\hline & $\begin{array}{l}\text { TSP: Greenhouse } \\
\text { Gas, Climate Change, } \\
\text { and Natural } \\
\text { Environment Policies }\end{array}$ & $\begin{array}{l}\text { Policies 3, } 4 \\
\text { Potential Action I }\end{array}$ & \\
\hline & VZ: Strategies & All Strategies & \\
\hline & VZ: Street Design & $\begin{array}{l}\text { 1st, 4th, and 7th Two- } \\
\text { year Actions }\end{array}$ & \\
\hline & $\begin{array}{l}\text { VZ: Engagement and } \\
\text { Accountability }\end{array}$ & $\begin{array}{l}\text { 5th Two-year Action } \\
\text { 6th Five-year Action }\end{array}$ & \\
\hline & $\begin{array}{l}\text { ATS: Action } 1 \text { - } \\
\text { Education }\end{array}$ & All subactions & \\
\hline & $\begin{array}{l}\text { ATS: Action 2- } \\
\text { Encouragement }\end{array}$ & All subactions & \\
\hline & $\begin{array}{l}\text { ATS: Action } 3 \text { - } \\
\text { Enforcement }\end{array}$ & All subactions & \\
\hline & $\begin{array}{l}\text { ATS: Action } 4 \text { - } \\
\text { Engineering }\end{array}$ & All subactions & \\
\hline & $\begin{array}{l}\text { CDH: Promote } \\
\text { Outdoor Lifestyles }\end{array}$ & Guideline 4 & \\
\hline & $\begin{array}{l}\text { CDH: Create a } \\
\text { Netowrk of Complete } \\
\text { Streets }\end{array}$ & Guidelines 1, 3, 5-9 & \\
\hline & $\begin{array}{l}\text { CDH: Emphasize } \\
\text { Walking, Biking, and } \\
\text { Riding Transit }\end{array}$ & All Guidelines & \\
\hline & CCEAP: Objective 13 & $\begin{array}{l}\text { All High Priority } \\
\text { Actions }\end{array}$ & \\
\hline
\end{tabular}




\begin{tabular}{|c|c|c|c|}
\hline \multirow{2}{*}{$\begin{array}{l}\text { New Mobility } \\
\text { Policy Topics }\end{array}$} & \multicolumn{3}{|c|}{ City of Eugene Policies and Actions } \\
\hline & CCEAP: Objective 15 & $\begin{array}{l}\text { High Priority Action } \\
15.1\end{array}$ & \\
\hline \multirow{7}{*}{$\begin{array}{l}\text { Congestion and } \\
\text { vehicle miles } \\
\text { traveled }\end{array}$} & $\begin{array}{l}\text { TSP: Transportation } \\
\text { System }\end{array}$ & $\begin{array}{l}\text { System-Wide Potential } \\
\text { Actions D, M, N }\end{array}$ & \multirow{7}{*}{$\begin{array}{l}\text { Eugene's policies related to } \\
\text { congestion and VMT are } \\
\text { primarily focused on congestion } \\
\text { management strategies and } \\
\text { GHG reduction. VMT is not } \\
\text { mentioned as a metric for } \\
\text { measuring or assessment. The } \\
\text { TSP does have language } \\
\text { around reducing single- } \\
\text { occupancy vehicles and } \\
\text { promoting non-gasoline powered } \\
\text { vehicles in its 'Greenhouse Gas, } \\
\text { Climate Change, and Natural } \\
\text { Environment Policies' section. }\end{array}$} \\
\hline & TSP: Transit Policies & $\begin{array}{l}\text { Policy } 1 \\
\text { Potential Actions B, C }\end{array}$ & \\
\hline & $\begin{array}{l}\text { TSP: Roadway and } \\
\text { Parking Policies }\end{array}$ & $\begin{array}{l}\text { Policy } 5,6,7 \\
\text { Action A } \\
\text { Potential Actions F, L, } \\
\text { M }\end{array}$ & \\
\hline & $\begin{array}{l}\text { TSP: Rail, Freight, and } \\
\text { Pipeline Policies }\end{array}$ & $\begin{array}{l}\text { Policy } 2,3,4 \\
\text { Potential Action E }\end{array}$ & \\
\hline & $\begin{array}{l}\text { TSP: Greenhouse } \\
\text { Gas, Climate Change, } \\
\text { and Natural } \\
\text { Environment Policies }\end{array}$ & $\begin{array}{l}\text { Policies 1, } 2 \\
\text { Potential Action A, F }\end{array}$ & \\
\hline & CCEAP: Objective 14 & $\begin{array}{l}\text { High Priority Actions } \\
14.2-14.3\end{array}$ & \\
\hline & CCEAP: Objective 16 & $\begin{array}{l}\text { High Priority Actions } \\
16.1 \mathrm{a}, 16.1 \mathrm{c}\end{array}$ & \\
\hline \multirow[t]{6}{*}{$\begin{array}{l}\text { Sustainability } \\
\text { and environment }\end{array}$} & $\begin{array}{l}\text { TSP: Rail, Freight, and } \\
\text { Pipeline Policies }\end{array}$ & Potential Action $\mathrm{K}$ & \multirow{6}{*}{$\begin{array}{l}\text { Existing policies that relate to } \\
\text { transportation and its effects on } \\
\text { the environment are found in } \\
\text { Eugene's TSP and Climate } \\
\text { Action plans. The Regional } \\
\text { Prosperity Economic } \\
\text { Development Plan that applies } \\
\text { to Lane County also calls for the } \\
\text { support of "of sustainable } \\
\text { businesses that work toward } \\
\text { building economies that are } \\
\text { green, local, and fair." While the } \\
\text { City's TSP does have a full } \\
\text { section entitled 'Greenhouse } \\
\text { Gas, Climate Change, and } \\
\text { Natural Environment Policies', } \\
\text { there is no metric established for } \\
\text { assessing baseline and future } \\
\text { rates of GHG emissions related } \\
\text { to vehicles and transportation. }\end{array}$} \\
\hline & $\begin{array}{l}\text { TSP: Greenhouse } \\
\text { Gas, Climate Change, } \\
\text { and Natural } \\
\text { Environment Policies }\end{array}$ & $\begin{array}{l}\text { All Policies and } \\
\text { Potential Actions }\end{array}$ & \\
\hline & CCEAP: Objective 10 & High Priority Action 10 & \\
\hline & CCEAP: Objective 15 & $\begin{array}{l}\text { All High Priority } \\
\text { Actions }\end{array}$ & \\
\hline & CCEAP: Objective 17 & $\begin{array}{l}\text { All High Priority } \\
\text { Actions }\end{array}$ & \\
\hline & EDP: Strategy 2 & Tactic 2.5 & \\
\hline \multirow{5}{*}{$\begin{array}{l}\text { Design and } \\
\text { management of } \\
\text { the right-of-way }\end{array}$} & $\begin{array}{l}\text { TSP: Transportation } \\
\text { System }\end{array}$ & System-Wide Policy 3 & \multirow{5}{*}{$\begin{array}{l}\text { Many of Eugene's current } \\
\text { planning documents touch on } \\
\text { various aspects of street and } \\
\text { right-of-way design. However, } \\
\text { there is no language that } \\
\text { addresses future mobility types } \\
\text { or potential changes in ROW }\end{array}$} \\
\hline & $\begin{array}{l}\text { TSP: Roadway and } \\
\text { Parking Policies }\end{array}$ & Policy 1 & \\
\hline & TSP: Transit Policies & $\begin{array}{l}\text { Potential Action A, } \\
\text { Item } 5\end{array}$ & \\
\hline & $\begin{array}{l}\text { TSP: Roadway and } \\
\text { Parking Policies }\end{array}$ & Potential Action F & \\
\hline & TSP: Bicycle Policies & Potential Action $\mathrm{H}$ & \\
\hline
\end{tabular}




\begin{tabular}{|c|c|c|c|}
\hline \multirow{8}{*}{$\begin{array}{l}\text { New Mobility } \\
\text { Policy Topics }\end{array}$} & \multicolumn{3}{|c|}{ City of Eugene Policies and Actions } \\
\hline & VZ: Strategies & $\begin{array}{l}\text { 1st Strategy, 2nd } \\
\text { Strategy, 4th Strategy }\end{array}$ & \multirow{7}{*}{$\begin{array}{l}\text { usage, such as increased curb } \\
\text { demand. Within these policies } \\
\text { and strategies, active } \\
\text { transportation modes are } \\
\text { specifically addressed, but there } \\
\text { is no hierarchical assignment of } \\
\text { modal priority to guide ROW } \\
\text { design and management. }\end{array}$} \\
\hline & VZ: Street Design & $\begin{array}{l}\text { 1st-8th Two-year } \\
\text { Actions } \\
\text { 1st-4th Five-year } \\
\text { Actions }\end{array}$ & \\
\hline & $\begin{array}{l}\text { ATS: Action } 1 \text { - } \\
\text { Education }\end{array}$ & Actions 1.3-1.4, 1.7 & \\
\hline & $\begin{array}{l}\text { ATS: Action } 3 \text { - } \\
\text { Enforcement }\end{array}$ & Actions 3.6, 3.10-3.11 & \\
\hline & $\begin{array}{l}\text { ATS: Action } 4 \text { - } \\
\text { Engineering }\end{array}$ & $\begin{array}{l}\text { Actions } 4.1-4.8,4.12- \\
4.13,4.15-4.18\end{array}$ & \\
\hline & $\begin{array}{l}\text { CDH: Design Smart } \\
\text { Parking and } \\
\text { Circulation }\end{array}$ & $\begin{array}{l}\text { Guidelines 1-2, 5, 11- } \\
12\end{array}$ & \\
\hline & CCEAP: Objective 14 & $\begin{array}{l}\text { High Priority Action } \\
14.2 \mathrm{~b}\end{array}$ & \\
\hline \multirow{2}{*}{$\begin{array}{l}\text { Changes in land } \\
\text { use and } \\
\text { metropolitan } \\
\text { footprint }\end{array}$} & $\begin{array}{l}\text { TSP: Transportation } \\
\text { System }\end{array}$ & $\begin{array}{l}\text { System-Wide Potential } \\
\text { Action D }\end{array}$ & \multirow[b]{2}{*}{$\begin{array}{l}\text { Eugene's TSP does recommend } \\
\text { the development of local metrics } \\
\text { for assessing changes in land } \\
\text { use and the transportation } \\
\text { system as a potential action } \\
\text { when local trends differ from } \\
\text { predictions based on national } \\
\text { standards. The Community } \\
\text { Climate and Energy Action Plan } \\
\text { for Eugene establishes the } \\
\text { creation of "20-minute } \\
\text { neighborhoods" as a land use } \\
\text { objective. }\end{array}$} \\
\hline & CCEAP: Objective 10 & High Priority Action 10 & \\
\hline \multirow{6}{*}{$\begin{array}{l}\text { Informed } \\
\text { decision making }\end{array}$} & VZ: Strategies & 5th Strategy & \multirow{6}{*}{$\begin{array}{l}\text { Many of Eugene's Vision Zero } \\
\text { sections discuss the need for } \\
\text { establishing measurable metrics } \\
\text { to assess and monitor current } \\
\text { transportation safety as well as } \\
\text { inform future decision making. } \\
\text { The 'Evaluation and Planning' } \\
\text { section of MoveEUG: Eugene's } \\
\text { Active Transportation Strategy } \\
\text { also discusses the same as a } \\
\text { means of monitoring and } \\
\text { developing safe and viable } \\
\text { pedestrian and bicycle networks. }\end{array}$} \\
\hline & VZ: Street Design & $\begin{array}{l}\text { 8th Two-year Action } \\
\text { 4th Five-year Action }\end{array}$ & \\
\hline & VZ: Impairment & 3rd Two-year Action & \\
\hline & $\begin{array}{l}\text { VZ: Engagement and } \\
\text { Accountability }\end{array}$ & $\begin{array}{l}\text { 1st and 3rd Two-year } \\
\text { Actions } \\
\text { 7th Five-year Action }\end{array}$ & \\
\hline & ATS: Action 5 & All subactions & \\
\hline & CP: Administration & Policy 10.8 & \\
\hline \multirow[t]{2}{*}{$\begin{array}{l}\text { Managing } \\
\text { innovation }\end{array}$} & $\begin{array}{l}\text { TSP: Roadway and } \\
\text { Parking Policies }\end{array}$ & Potential Action $\mathrm{H}, \mathrm{I}$ & \multirow{2}{*}{$\begin{array}{l}\text { Eugene's TSP does recommend } \\
\text { different types of user-oriented } \\
\text { and system-based technologies }\end{array}$} \\
\hline & $\begin{array}{l}\text { TSP: Pedestrian } \\
\text { Policies }\end{array}$ & Potential Action A & \\
\hline
\end{tabular}




\begin{tabular}{|c|c|c|c|}
\hline \multirow{9}{*}{$\begin{array}{l}\text { New Mobility } \\
\text { Policy Topics }\end{array}$} & \multicolumn{3}{|c|}{ City of Eugene Policies and Actions } \\
\hline & VZ: Street Design & 3rd Two-year Action & \multirow{8}{*}{$\begin{array}{l}\text { to improve traffic safety and } \\
\text { encourage transit and rideshare } \\
\text { use as potential actions. The } \\
\text { 'Street Design' section of the } \\
\text { City's Vision Zero program } \\
\text { recommends the use of pilot } \\
\text { projects for testing and } \\
\text { assessing potential } \\
\text { transportation safety } \\
\text { interventions. More broadly, the } \\
\text { Envision Eugene } \\
\text { Comprehensive Plan calls for } \\
\text { responsible economic } \\
\text { development that aligns with } \\
\text { community goals and for the } \\
\text { development of a means of } \\
\text { assessing how development is } \\
\text { aligning with the city's more } \\
\text { qualitative quality-of-life goals. }\end{array}$} \\
\hline & $\begin{array}{l}\text { CP: Overall Economic } \\
\text { Development } \\
\text { Objectives }\end{array}$ & Policy $3.6,3.29$ & \\
\hline & CP: Administration & Policy 10.8 & \\
\hline & $\begin{array}{l}\text { CDH: Design Smart } \\
\text { Parking and } \\
\text { Circulation }\end{array}$ & Guidelines 5, 11-12 & \\
\hline & EDP: Strategy 1 & Tactic 1.3 & \\
\hline & EDP: Strategy 2 & Tactic 2.5 & \\
\hline & EDP: Strategy 4 & Tactics $4.2,4.4$ & \\
\hline & EDP: Strategy 6 & Tactic 6.1 & \\
\hline $\begin{array}{l}\text { Fiscal impacts of } \\
\text { new mobility } \\
\text { revenue }\end{array}$ & $\begin{array}{l}\text { TSP: Cost } \\
\text { Effectiveness and } \\
\text { Finance Policies }\end{array}$ & $\begin{array}{l}\text { All Policies and } \\
\text { Potential Actions }\end{array}$ & $\begin{array}{l}\text { The City's 'Cost Effectiveness } \\
\text { and Finance Policies' section of } \\
\text { its TSP calls for looking at full } \\
\text { lifecycle costs of potential } \\
\text { facilities and favoring cost } \\
\text { efficiency in transportation } \\
\text { systems. Preserving the existing } \\
\text { system is a priority, followed by } \\
\text { improving efficiency and adding } \\
\text { capacity to the system. }\end{array}$ \\
\hline
\end{tabular}

Sources and key: Preliminary scan by Urbanism Next of the TSP - Eugene 2035 Transportation System Plan (2017); VZ - Vision Zero Eugene (2017), ATS - MoveEUG: Eugene's Active Transportation Strategy (2017-2021); CP - Envision Eugene Comprehensive Plan (2017); CDH - DRAFT Community Design Handbook (2007); CCEAP - Community Climate and Energy Action Plan for Eugene (2010); and EDP Regional Prosperity Economic Development Plan: Eugene, Springfield, Lane County (2010).

Included in the list are policies and action items that represent opportunities for expansion or elaboration that could help address new mobility policies. These opportunities are:

\section{Active Transportation: Modal prioritization}

- Opportunity: TSP: Roadway and Parking Policy 1, the "Complete Streets Policy," states that "(a) 'complete street' allows safe travel for automobiles and emergency responders, bicycles, walking, transit, and freight" but does not specify which of these uses has priority in the street. 
- Recommendation: Establishing a street usage prioritization that caters to the needs of pedestrians, cyclists, transit, and emergency vehicles over personal automobiles could help support safety, active transportation, sustainability, and community livability goals.

\section{Design and Management of the Right-of-Way: Local deliveries}

- Opportunity: The Community Climate and Energy Action Plan for Eugene's High Priority Action 16.1c calls for a freight transportation system that "(f)acilitates efficient local deliveries" in order to reduce GHG emissions.

- Recommendation: Given the trend toward increased numbers of local deliveries with the rise in e-commerce orders and courier network service deliveries, this action could be updated to focus on both efficiency in terms of fuel usage and GHG emissions as well as efficiency in terms of facilitating delivery ease via curb management techniques.

\section{Changes in Land Use and Metropolitan Footprint: Park-and-ride facilities}

- Opportunity: TSP: Transit Policies Potential Action B suggests that the City "(c)oordinate with Lane Transit District (LTD) to expand the park-and-ride system within Eugene's commute shed with an emphasis in developing partnerships to share existing parking facilities." The City of Eugene's policies assume that driving a personally owned vehicle will be one of the primary modes of movement in the City.

- Recommendation: If new mobility does reduce reliance on personally owned vehicles, then this assumption would need to be updated in transportation and land use plans. The City may want to reassess the need for park-and-ride facilities in the long term. The City may want to consider phasing out close-in park-and-rides as personally owned vehicle use decreases and new mobility services and transit increase.

\section{Changes in Land Use and Metropolitan Footprint: Street parking}

- Opportunity: The Draft Community Design Handbook Design Smart Parking and Circulation Guideline 1 calls for the City to "(p)rioritize on-street parking" while Guideline 2 encourages the City to "(u)tilize shared-parking strategies within development sites and at the district scale."

- Recommendation: New mobility services have the potential to decrease the demand for parking, meaning that prioritizing on-street and shared parking strategies over surface lots will continue to be smart land use strategies. However, the changing nature and increasing demand of curb space by new mobility services could change the demand for spaces currently allocated to onstreet parking. Maintaining a mix of parking, loading zones, transit access, and micromobility access along the curb could help balance the demands for these spaces. 


\section{Informed Decision Making: Data collection}

- Opportunity: TSP: System-Wide Policies Potential Action S calls for the City to "Collect and report crash data for all travel modes...".

- Recommendation: Expanding this policy to include broader information about new mobility services, such as trip start and end locations, timing, and other ridership details, could provide the City with the information they need to make their current transportation and transit systems much more efficient and thus better serve their users.

The most significant gaps or policy areas that are not identified in existing plans that the City could consider are:

\section{Social Equity}

- Gap: While the City has goals, policies, and action items related to providing transportation access to low-income, vulnerable, and underserved populations, there is no specific guidance for access, payment options for the unbanked, equitable workforce policies, or accommodating people with disabilities.

- Recommendation: Determine if the City wants to create policies that specifically address equity. Transportation equity policies can address specific geographic areas or the city as a whole. Policies requiring cash payment options for the unbanked, outlining accessibility requirements for people with disabilities, and equitable workforce conditions for those working as contractors with new mobility service providers are all examples of ways the City can promote equitable practices in a changing transportation landscape.

\section{Reduce congestion and vehicle miles traveled}

- Gap: Eugene's current policies related to congestion do address alternatives to personal automobiles, such as transit and active transportation modes, but lack a way to establish quantitative data on baseline or future use.

- Recommendation: Adding VMT as a metric for assessing modal split and transportation efficiency would provide a quantifiable means for formulating transportation-related goals and measuring their progress while also promoting non-vehicular modes of travel.

\section{Design and management of the right-of-way:}

- Gap: The impacts of newly emerging mobility trends suggest that the City will need to take a new approach to managing the ROW and especially the curb, specifically in high-demand locations like downtown and BRT stations.

- Recommendation: The City will need to understand changes in demand for the curb for both passengers and freight and goods delivery. Accommodating this increased demand can also pair with projected decreases in parking demand, allowing the City to take a fresh look at space allocation throughout the ROW and reassign less efficient uses to those which meet these new and growing demands. 


\section{Changes in land use and metropolitan footprint}

- Gap: Many of Eugene's policies already encourage compact urban form, transitoriented development, and a pedestrian-friendly downtown area; however, these plans assume that personally owned vehicles will be one of the primary modes of transportation for residents.

- Recommendation: New mobility services increase the uncertainty of the demand for parking in the future, which could increase the risk of publicly financed parking structures. The City should conduct a full risk assessment of any new parking structures, using pricing strategies to help manage the demand for parking in high-demand locations, and invest in alternative modes more aggressively to accommodate the demand for access. In addition, the City may want to reconsider minimum parking requirements and consider strategies to redevelop parking lots and structures if new mobility services decrease the demand for parking in the future.

\section{Informed decision making}

- Gap: The City of Eugene currently does not have any policies that require new mobility service providers to share data with the City.

- Recommendation: In addition to collecting crash data as suggested under its Vision Zero policies, gathering usage data from new mobility providers will also help Eugene's City staff understand how they can meet transportation-related safety, mode share, equity, and GHG emissions reduction goals. This information is also critical for enforcement of requirements and fees for new mobility service providers (if applied). The City of Eugene should review the Los Angeles Data Mobility Specifications and review the work of the City of Portland, which adapted this standard to collect data from e-scooter companies, to adopt a data standard.

\section{Managing innovation}

- Gap: While the City of Eugene has formal relationships with regional partners (Lane Council of Governments, Lane Transit District, and surrounding jurisdictions), coordination on new mobility issues is nascent. Many larger cities where new mobility deployments are happening first are trying to better manage impacts by conducting pilot projects. The City of Eugene does not have a pilot project process, but instead has rolled out projects for implementation (bikeshare and TNCs).

- Recommendation: The City of Eugene should consider if they want to formally coordinate with regional partners. At a minimum, the City should work closely with Lane Transit District as a key partner to achieving community goals. 


\section{Fiscal impacts and new mobility revenue}

- Gap: Eugene has no adopted policies that specifically require new mobility services fund transportation infrastructure and assess its impact on the transportation system.

- Recommendation: The City should evaluate different fee options to create a funding mechanism that helps the City achieve its goals, including paying city costs for managing new mobility (permitting, enforcement, evaluation, etc.), paying for the impact on transportation infrastructure and the transportation system, and investments that increase capacity and throughput of people and goods.

Eugene currently has a wide range of policies that can help shape the growth of new mobility services in ways that meet the goals of its community, although the strength and approaches of these policies vary by plan document. By reprioritizing and reframing policy language to prioritize active transportation, transit, and equitable transportation access, the City of Eugene could ensure that potentially disruptive new mobility technologies continue to align with the City's core values pertaining to transportation, safety, land use, and GHG emissions reductions.

As the City of Eugene updates and revises its planning documents, establishing a hierarchical transportation mode prioritization could help unify goals, policies, and actions across the City's different plans. It will also be helpful to keep in mind emerging technology trends and how they could impact land use, transportation, urban design, and real estate. The potential reductions in demand for parking, changes in the ways people shop for and receive goods, and increases in demand for curb space will all affect how communities interact with their urban infrastructure. Allowing a degree of regulatory flexibility that does not compromise on established community goals can help the City navigate these changes in ways that are beneficial for Eugene's community both in the short and the long term. 


\subsection{SUSTAINABLE CITY YEAR PROGRAM CLASS FINDINGS}

One of the goals of this project was to introduce students to new mobility topics and recruit them to help the Cities of Gresham and Eugene tackle new mobility issues. The 147 students in eight classes researched a number of key questions, exploring new mobility issues from a variety of approaches. This chapter describes the key questions, key findings, and recommendations (if included) from the Sustainable City Year Program (SCYP) projects across several classes.

\subsection{IMPACTS OF AUTONOMOUS VEHICLES ON TRANSPORTATION REVENUES}

The 27 students in the Public Budgeting class were asked to answer three key questions:

- How is transportation currently funded in the cities of Gresham and Eugene?

- Given specific scenarios, how are revenues likely to be impacted by AVs?

- What are your recommendations for replacing revenue?

The key findings and recommendations are summarized from the Transportation Revenue in the Age of New Mobility report (Stark and Lewis, 2018).

\section{Key findings}

The City of Eugene currently raises $\$ 29.2$ million in transportation-related revenue. Under each scenario, Eugene could expect a decrease in revenue collected through its airport parking fees and the motor vehicle fuel tax. In addition, Eugene would receive less pass-through funding from the State; revenue from the State Highway Fund, HB2017, licenses, and permits would decrease.

We estimate the City of Eugene's transportation-related revenue would be $\$ 9.5$ million under Scenario A and \$7.3 million under Scenario B, a decline of $68 \%$ and $75 \%$, respectively (Appendix A). The City of Gresham currently raises $\$ 21.7$ million in transportation-related revenue. Gresham could expect a decrease in revenue collected through its own parking fines as well as pass-through funding from the State Highway Fund. We estimate the City of Gresham's transportation-related revenue would be $\$ 11.7$ million under Scenario A and $\$ 10.8$ million under Scenario B, a decline of $46 \%$ and $50 \%$, respectively.

\section{Recommendations}

Collectively, the students identified 13 innovative sources of revenue that could help cities recoup lost revenue. The students evaluated each source based on equity, neutrality, efficiency, and productivity. Each student group then recommended a funding package for Eugene or Gresham based on their analysis. 
To achieve success, we recommend each city take the following measures:

- Adopt a combination of revenue sources to provide resilient, stable funding that will withstand future changes in technology and distribute the tax burden widely.

- Coordinate regionally or push for the adoption of state taxes to mitigate potential location effects (changes in behavior based on policy differences between jurisdictions), increase collection efficiency, and reduce local administrative burden.

- Consider adopting at least one high-yield revenue source such as a vehicle miles travelled (VMT) tax.

- Address potential equity issues by implementing tiered rate fee systems for some revenue sources, including the VMT tax, the electric vehicle charging tax, TNC ride fees, tolls for roads and bridges, and shared use parking.

- Address potential traffic congestion by implementing congestion pricing, "zombie" AV taxes, and pick-up/drop-off zones for TNCs.

- Consider new mobility's potential impact on public transit and take appropriate steps to ensure long-term access to transportation options.

\subsection{CAN NEW MOBILITY SERVICES REDUCE RELIANCE ON SINGLE-OCCUPANCY VEHICLES?}

Each of the 23 student pairs in the Industrial Ecology class were tasked to answer the key question: How could members of a fictional or real household in Eugene reduce their reliance on SOVs when traveling? This section is a summary of the key findings from the New Mobility Case Study report (Cohen and Skov, 2018).

Students compared the cost and time, as well as health, environmental and other benefits, of using a SOV to other modes. Students considered the opportunities, tradeoffs, and barriers to adoption of non-SOV modes. Students considered three types of trips:

- Daily trips like commuting to work, school, or other locations

- Other regular trips like grocery shopping or medical appointments

- Long-distance trips for work or vacation

\section{Key findings}

The analysis highlights four components that may play out in policymaking:

- Student analysts struggled to fully account for the opportunity costs and time value of money. This is a potential warning for policymakers as well as, like students, citizens may have difficulty in perceiving the economic trade-offs between modes. 
- The analysis did not fully take into account the potential health benefits of active transportation.

- The students brought their biases around safety of different modes into their analysis and assumed that modes they were unfamiliar with were unsafe.

- Students did not always account for the total amount of time needed for each mode. For example, they used Google Maps to estimate the time to walk, bike, take transit, or drive; however, they did not account for the time in congested traffic or looking for parking when calculating drive times.

These insights highlight the challenges of comparing the pros and cons of different travel choices.

- Overall, they found that households that were younger, with higher incomes, no children, and in places with strong walk, bike, and transit infrastructure and service benefited the most from new mobility solutions.

- Any significant move to reduce SOV use is to improve most or all multimodal options. That includes:

- Higher-frequency transit service, improvements, and partnerships

- Contingency options, such as guaranteed rides home by taxi or TNCs

- New mobility education and tools to combat biases and improve awareness that more accurately reflects reliability, safety, and accessibility

\subsection{FUTURE-PROOFING COMPREHENSIVE PLANS FROM NEW MOBILITY IMPACTS}

The key findings and recommendations are summarized from the Future-Proofing Comprehensive Plans in Eugene and Gresham report (Kohnke and Lewis, 2019). The 15 students worked in groups in the Growth Management class and were asked to answer the following key questions:

\section{Key questions}

- How do comprehensive plans address e-commerce and new mobility?

- How are comprehensive plans prepared for the introduction of AVs and new mobility?

- What are recommendations for improving comprehensive plans?

\section{Key findings}

- E-commerce may lead to mid-sized distribution centers locating close to places of higher population densities.

- E-commerce may impact storefront retail base of traditional brick-and-mortar by changing the use and tenure of commercial spaces.

- Mid-sized e-commerce distribution centers may have additional impacts on local freight and street networks.

- New mobility may lead to a reduction in the amount of parking needed, warranting a change in development codes. 
- Current comprehensive plans do not adequately address e-commerce or new mobility.

- To address the impacts of e-commerce and new mobility, cities should define the terms, expand allowable uses within some zones, and adapt parking regulations.

\section{Recommendations}

- To future-proof for e-commerce:

o Change zoning codes to explicitly designate locations for e-commerce

o Alter commercial zones to allow certain types of manufacturing and distribution to allowable uses

o Identify which zones are preferred for distribution hubs

o Adopt policies to require on-site package storage and loading and delivery drop-off in residential areas

o Allow mixing of uses with industrial, residential, and commercial zones to facilitate delivery and distribution hubs

o Identify redevelopment areas ripe for e-commerce

o Develop warehouse overlay zones

o Develop loading zones in new commercial and residential developments

o Allow lockers within the public right-of-way in neighborhoods (five-minute walking radius) to better serve the consumer, as well as provide better access to secure purchasing and delivery

o Dedicate curb space in the public right-of-way for loading and unloading

- To future-proof for new mobility:

o Define new mobility within city plans and policies

o Reduce parking requirements for residential and commercial development in infill areas and near transit hubs

o Develop specific parking management provision addressing drop-off locations

o Consider regulations and taxes to minimize VMT in order to contain growth and promote 20-minute neighborhoods

o Alter development codes to allow for residential garages to be repurposed as housing

o Revise design standards for parking structures to allow for adaptive re-use of obsolete parking garages

\subsection{HOW CAN CITIES PLAN FOR PARKING AND BICYCLE INFRASTRUCTURE IN A NEW MOBILITY FUTURE?}

The 20 students in the Transportation Planning class gathered data about the existing transportation infrastructure in Gresham and Eugene. The key findings and recommendations are summarized from the Planning for a New Mobility Future report 
(Crum and Brown, 2019). The students were asked to answer the key question: How should each city address issues related to parking and bicycle infrastructure when considering new mobility policies in either downtown Gresham or Eugene?

\section{Key findings for both cities}

- Some promising efforts to improve e-scooter parking compliance through education (interactive maps by the City of Austin); fines of up to $\$ 500$ for companies (City of San Francisco); or credits or charges for proper parking jobs (PeaceHealth Rides, City of Eugene).

- Cities around the country encourage or require e-scooters to operate on the street in bike lanes. They generally are not allowed to operate on sidewalks.

\section{Recommendations for the City of Gresham: Parking}

Gresham parking rarely exceeds $85 \%$ occupancy, generally considered a threshold for instituting paid parking. This implies that Gresham has an overabundance of free parking in the city. The student researchers recommend that Gresham "...consider employing transit-selective parking requirements strategically to encompass other modes going forward" (Crum and Brown, 2019, p 24). Students also recommended the city:

- Designate curb space specifically for loading and unloading.

- Implement marked parking time limits in high-demand zones and create a system of parking stickers or tags for employees to exceed the time limit.

- Institute a pay-to-park system in the future when parking utilization exceeds $85 \%$ on a regular basis.

- Institute a land-value tax to encourage development, especially on underutilized, privately owned parking lots.

- Create a pedestrian-only mall closed to vehicular traffic on a section of Main Street.

- Work with TriMet to create a multimodal transit card. ${ }^{4}$

- Limit parking downtown and replace vehicle parking with bicycle and e-scooter parking. The City should explore the use of shuttles to move people from parking lots or structures to and around downtown.

\section{Recommendations for the City of Gresham: Micromobility}

- Reutilize underused parking spaces to other uses such as food carts, parklets, café seating, loading and unloading zones, or micromobility parking for bicycles or e-scooter share systems.

- Launch a micromobility pilot project.

- Create micromobility lanes (either protected or unprotected).

\footnotetext{
${ }^{4}$ Note that TriMet's Hop Card allows for flexibility and savings when purchasing transit rides. In addition, TriMet is testing multi-modal trip planning (https://betaplanner.trimet.org/map/\#/) and may at some point in the future marry these two efforts together to allow people to plan and pay for multi-modal trips via the Hop Card.
} 


\section{Recommendations for the City of Eugene: Parking}

- Designate four parking spaces along Broadway Street between Willamette and Olive streets for loading and unloading between 8 p.m. and 4 a.m. every night. At the $5^{\text {th }}$ Street Market, convert approximately four parking spaces for loading and unloading, two at the south side of $5^{\text {th }}$ Avenue at Pearl Street and two at the east side of High Street at $5^{\text {th }}$ Avenue.

- Increase parking in locations with utilization above 85\% occupancy (Broadway and Willamette).

\section{Recommendations for the City of Eugene: Micromobility}

- Create micromobility parking corrals with paint or plastic bollards when/if escooters are allowed.

- Transition bike lanes into micromobility lanes to accommodate e-scooters when/if they are allowed.

- Consider an e-scooter pilot with an extensive education component.

- Cap the number of e-scooters to 700 vehicles and institute a $\$ 0.25$ per-trip surcharge along with a permit fee to be determined by the City.

- Implement a reward and fee system for e-scooter parking.

- Require deployment of e-scooters in low-income and underserved areas.

- Build protected micromobility lanes.

\subsection{URBAN DESIGN OPTIONS FOR DOWNTOWN GRESHAM}

The 14 students in the Future of Urban Design and Planning Advanced Design Studio explored the redesign of several streets and the historic downtown core in consideration of anticipated shifts in urban transportation, including ridesharing, micromobility, and autonomous driving, as well as the probable reduced demand for parking and the expectation of downtown becoming more densely populated with residents over time. The key findings in this section are summarized from the Exploring New Mobility Street Design for a Suburban Downtown in Transition (Ribe and Tamang, 2019). For each project, students provided:

- Detailed existing conditions of the study area

- Transitional designs for the transitional period, "from current street-use patterns to 'urbanism next' ones"

- Long-term designs

\section{Key findings}

The projects offer an array of design strategies, including one project offering code suggestions to promote community engagement, pedestrian safety, transit connectivity, and green spaces. The solutions are street and site specific, but common themes appear throughout the students' work and apply to other locations. 
- Transform areas to be human-centered/pedestrian-oriented. Students illustrated how the City could change certain streets to be accessible to pedestrians only or pedestrians and slower-speed vehicles, like bicycles. Closedoff streets will allow access to emergency vehicles and scheduled delivery vehicles. This could be done by creating "play streets" or by closing off Fourth Street for events and programming.

Where vehicles cohabitate with pedestrians, students suggested implementation strategies for pedestrian safety and accessibility, including curbless streets, frequent crossing opportunities, curb extensions, lighting, signage, and ADA ramps. They also suggested increasing the number of public spaces, including parklets, seating, shaded spaces and plazas, to make Gresham more inviting to visitors and help transform the area into a social hub. Establishing public easements to encourage permeability between the public and private sectors and supplying public areas for people watching could be encouraged.

- Improve or expand existing public transportation routes, stops, and micromobility to promote human-focused streets and reduce last-mile issues. The students emphasized the importance of transit and suggested expanding existing public transit routes and stops, including using the light rail as one of the main transportation modes into the downtown. One project recommended connecting the Gresham Central MAX station and City Hall with two jitney/bus routes and downtown hubs to transport pedestrians into the downtown area and reduce private vehicle dependency. Another project proposed creating greenway connected hubs in the historic downtown northwest corner of $5^{\text {th }}$ Street and Miller Avenue and at the southeast corner of Hood Avenue and $2^{\text {nd }}$ Street. The students proposed developing the hubs with renovated buildings, small shops, and multiuse plazas. The projects illustrated the need to improve connectivity within transit and transit hubs, greenways, and pedestrian routes.

- Reconfigure existing right-of-way and street lanes to achieve safety and pedestrian-oriented goals. Transformation suggestions include replacing conventional vehicle lanes and/or creating separate lanes for carshare, eshuttles, bikes, flex zones, AVs, buffers, and parklets. The projects provided numerous examples of protected bike, micro-vehicle, and pedestrian lanes using strategies like medians, curbs, or planters to divide bike and pedestrian lanes from traffic lanes.

They noted the importance of signage to explain new types of vehicular circulation. They also suggested delineating pedestrian and travel lanes as well as intersections to signal a change in use through paint, textured materials, paving patterns and colors, decorative plantings and furniture, curb extensions, 
and setting back crosswalks for safety as well as creating vibrant spaces.

- Limit, reduce, eliminate, or repurpose existing parking. Limit or reduce onstreet parking as a transitional phase, eventually eliminating on-street city parking in pedestrian-oriented areas. Parking lots could be eventually repurposed into parklets, planters, micromobility parking, or AV pick-up/drop-off zones.

- Employ strategies to encourage density, including mixed-use (live/work) redevelopment. Blend residential and commercial areas through mixed-use buildings and the addition of smaller residences like micro-housing; low-rise village-style/cottage homes; rowhouses; and tiny homes. The City should supply amenities to promote walkability and improve residential quality, like grocery stores.

- Plant vegetation for safety buffers, stormwater management, enjoyment, ecological benefits, and microclimate controls. Students suggested that the City could reduce stormwater runoff through stormwater planters and rain gardens placed adjacent to large areas of non-impervious surfaces. Planters and gardens can also function as safety buffers between vehicular and pedestrian traffic.

- Establish "a community character." Use design elements like color, patterns, paver patterns, and rhythm continuity to create a cohesive aesthetic. Use educational signage, key markers, and art sculptures as wayfinding and interactive elements.

\subsection{POLICY SUGGESTIONS FOR NEW MOBILITY-RELATED TRANSPORTATION SYSTEM PLAN UPDATES}

The three students in the Masters of Public Administration Capstone class spent Winter and Spring term studying new mobility policy topics for Gresham and Eugene's Transportation System Plan related to safety, equity, land use, innovation, environmental impact, congestion and vehicle miles traveled, active transportation, and data. The key findings here are summarized from the report Transportation Policy Options: New Mobility Services and Autonomous Vehicles (Duffey et al., 2019).

The key question that the students asked was: How should the cities of Gresham and Eugene update their Transportation System Plans to adapt to new mobility services?

\section{Key findings}

- Data requirements and privacy. The report authors recommend that the cities of Gresham and Eugene use standardized data requirements such as those 
developed by the City of Los Angeles. They also recommend restricting the data that can be requested via the Freedom of Information Act to protect the privacy of individuals. Given the potential cost and privacy considerations, contracting with a third-party vendor may be a good option for the cities. Finally, the report authors recommend the development of data-driven performance metrics to achieve equity, safety, quality and operation of service standards.

- Equity. Create options for unbanked people to use new mobility services that don't require a credit card and allows them to pay cash. Establish sliding scale fees for low-income residents. Create a customer "bill of rights" that requires providers to provide a safe, clean ride free of discrimination, harassment, and criminal activity. They also suggest requiring service in underserved areas and the usage of infographics and pictures for instructions when language translation is not an option.

- Safety. The students suggested that cities should take the lead to ensure new mobility options operate safely within city limits. They suggest that e-bikes and escooters should have an internal speed limit of $12 \mathrm{mph}$ and require providers to include user agreements with safety information. E-scooters should be banned from sidewalks and pedestrian-only zones. The report authors recommend a fingerprint background check for TNC drivers to determine a criminal background. They also recommend a one-hour window to remove vehicles blocking access or sidewalks. Safety requirements should be included in the permitting process and service providers should be required to conduct routine safety inspections.

- Land use. The students suggest that some parking spaces should be redesignated as pick-up and drop-off zones as well as encourage the redevelopment of parking garages to other uses.

- Innovation. Invest in 5G network and electric charging infrastructure for AV implementation. Hire full-time, dedicated new mobility staff with technical data skills and a policy or planning background.

- Active transportation. Create a universal rider/user transit pass, with subsidies for lower-income users. Create or repurpose multimodal hubs for first-/last-mile transportation.

- Environmental impact. Adopt sustainability requirements for mobility products (i.e., product lifespan, materials). Phase out the City's gas-powered vehicles with electric vehicles. 
- Congestion and vehicle miles travelled. Adopt congestion pricing fees adapted from Portland's proposed model. Geofence new mobility vehicles during traffic hours.

\subsection{HOW SHOULD CITIES THINK ABOUT DATA?}

The key questions asked by the seven students in the Public Management class were:

- What policy elements should be incorporated into data requirements for transportation providers for the City of Gresham?

- What policy elements should be incorporated into an open data management plan for the City of Eugene?

Key recommendations for the City of Gresham and data requirements:

- E-scooter and bikeshare companies. The City of Gresham should model their data requirements on the City of Portland and the City of Seattle requirements. The City of Gresham should consider monthly check-ins with the companies to ensure regulatory compliance and address safety issues.

- Transportation network companies. The City of Gresham should consider adopting regulations similar to the City of Seattle that include (1) definition of TNCs and licensing available to them; (2) definition of acceptable routes and excludable areas of operation; (3) controlling rates per ride, city taxes paid by users, and fee collection; and (4) standards for driver hires and safety equipment standards. The researchers also recommend that the City of Gresham adopt Portland's fee of $\$ 0.50$ per ride for regional continuity.

- Autonomous vehicle companies. The City of Gresham should consider adopting the following elements with AV regulations: (1) prioritize safety, (2) remain technologically neutral, (3) modernize regulations, (4) encourage a consistent regulatory and operational environment, and (5) include a data requirement.

Key findings for the City of Eugene and open data policies:

- Engage with resources at the University of Oregon. University of Oregon's students and the Oregon Policy Lab are assets that the City of Eugene can use to gather additional data and conduct analysis. 
- Create an open data policy. The City of Eugene should develop an open data policy that follows best practices.

- Invest resources to develop a coproduction program. There are a number of opportunities to create an open data policy and then ensure that data is easily accessible on the City's website, and that it links to other programs such as Vision Zero. In addition, the City should ensure that the information is ADA accessible.

\subsection{WHAT CAN OTHER CITIES TELL GRESHAM AND EUGENE ABOUT POLICIES THAT ENCOURAGE NON-AUTOMOBILE TRANSPORTATION?}

The key question asked by the 14 students in the Land Use Planning and Policy class was:

- What can the City of Eugene learn from other case study cities about how to make downtown more accessible to non-automobile means? Focus on parking management, sustainable transportation, and transportation demand management.

The key findings in this section are summarized in the report Community Strategies for Improving Accessibility and Sustainable Transportation in Downtown Eugene (Hoagland, Theofield and Yang, 2019).

\section{Key Findings}

- Sustainable transportation. Students found that the most successful cities invested heavily in alternative modes such as bike boulevards, bicycle parking, and protected bike lanes. These cities also invested in transit, from making transit stations safer with better lighting to programming space to make it busy at all times. Some cities charge a tax just for transit. All cities studied had multiple transportation demand management programs to reduce dependence on automobiles. Investment in pedestrian facilities is extensive in these cities, as well as the overall prioritization of non-automobile modes generally.

- Parking management. Cities across North America are trying a wide range of non-traditional programs and tools to reduce reliance on automobiles, such as providing low-cost parking for carpools and vans, requirements to unbundle the cost of parking from housing, creating parking benefit districts, and much more.

- Transportation demand management. All of the cities studied provided a wide range of transportation demand management (TDM) programs and tools to get people out of cars. These programs included providing free transit passes to 
students and business employees (participating in a transit program) as well as low-income seniors and the disabled. There are almost always commuter programs, sometimes coupled with parking cash-out programs.

\section{Key Recommendations}

The students made the following recommendations for the City of Eugene:

1. Develop subsidized transit pass program like EcoPass (Denver region)

2. Create a Commuter Check Program for City and private employers

3. Implement app-based parking management program like goBerkeley

4. Utilize public parking facilities management and activation

5. Invest in alternative transit-supportive facilities and infrastructure

6. Adopt frequent travel networks and areas

7. Develop additional parking fees

8. Create an employee trip reduction plan/compass for organizations

9. Develop and implement a pavement-to-plazas and parklets program

10. Develop a new mobility research grant program

11. Improve listed accessibility standards of the bicycle and pedestrian networks

12. Expand level of service (LOS) standards to include multimodal transportation networks

13. Use regular assessments to track progress on projects, plans and policy success

14. Implement aspects of Bellingham's Smart Growth Model

15. Incorporate the commute trip reduction program

16. Expand the TOD overlay between the university and downtown

17. Enhance university partnerships

18. Enhance TDM

19. Improve bikeshare accessibility

20. Minimize curb-space usage

21. Set measurable objectives, monitor, and track progress

22. Develop a neighborhood access tool in partnership with Lane Transit District and integrate it into planning

23. Adopt the SUMP (Shared, Unbundled, Managed, and Paid Parking) principles to guide parking management

24. Integrate more flexibility into the City's strategy

25. Create a flex zone pilot project

26. Adopt innovative project metrics

27. Adopt performance-based parking

28. Develop curbless streets

29. Increase partnerships with LTD

30. Incorporate a hierarchy of transportation and mobility priorities for downtown

31. Legalize skateboarding within downtown

32. Integrate a standardized wayfinding system within Eugene

33. Incorporate pedestrian through-block walkways within downtown

34. Expand bicycle network and bicycle amenities within downtown 


\subsection{NEW MOBILITY STRATEGY AND POLICY RECOMMENDATIONS}

The introduction of new mobility services and the growth of e-commerce is rapidly changing transportation systems across the United States and in Oregon. The cities of Gresham and Eugene understand that they need to tackle these issues head-on. The Urbanism Next Center has the following recommendations for each of the cities based on the research summarized in this report. This chapter brings together the key findings from the Navigating New Mobility Report and the SCYP class reports to make overall recommendations for strategies and policies for the cities of Gresham and Eugene. It also reflects the input from Gresham and Eugene city staff generated from workshops as to what issues are most important to each city.

This chapter is organized into two sections: (1) New Mobility Strategy and (2) Policy Recommendations. The most effective strategies begin with well-articulated goals that clearly describe the underlying values they are designed to address and the outcomes they should achieve. Each city should consider developing a new mobility strategy to guide changes in transportation, land use, environmental, and other plans. This strategy could be incorporated into existing planning documents, such as the transportation system plan or comprehensive plan. Or, the strategy could be a separate document that focuses on new mobility and e-commerce.

A new mobility strategy should address the policies that are the most important to each city. We identify 10 policy areas that we believe are the most relevant for new mobility strategies to address.

\subsection{NEW MOBILITY STRATEGY}

\subsubsection{Start with community values and goals}

Both Gresham and Eugene have transportation network companies operating on city streets. Bikeshare operates in Eugene, and there is the possibility of e-scooters expanding into Gresham and deploying in Eugene. Even if AVs are years from deployment, a new mobility strategy that clearly articulates community values and goals would be beneficial.

We recommend that the City of Eugene focus on the values and goals described in the Eugene 2035 Transportation System Plan, Vision Zero Action Plan, the Active Transportation Strategy, and the Climate Action Plan. The City of Gresham's Transportation System Plan, Active Transportation Plan, and Comprehensive Plan articulate policies that are important to city residents. Specifically, the cities should ensure that new mobility and e-commerce policies address the following:

- Reduce fatalities and serious crashes. The cities should ensure that the street right-of-way and multiuse paths are safe for all users and that policies and 
regulations increase safety and security, as well as reduce conflicts between modes. Cities across the country are thinking about how they can design the right-of-way to decrease conflicts as well as ensure that new mobility services don't obstruct sidewalks or bike lanes.

- Ensure a fair and just transportation system for all. Eugene and Gresham should ensure that all residents and visitors have access to the transportation system they need, regardless of their income or where they live. The cities should make sure that technology used in Gresham and Eugene accommodates the unbanked as well as those who don't speak English. Given that many new mobility modes provide significant benefits for younger, more affluent, educated, and childless adults, the cities should consider the impact of the services on those with lower incomes, people with children, seniors, and people with disabilities.

- Prioritize healthy, low-carbon, active transportation options and promote walking, biking, and transit over the use of single- (or zero-) occupancy vehicles. Eugene and Gresham's policies clearly define the importance of walking, biking, and transit to public health and the environment. New mobility policies should encourage these modes. Policies should focus on activities that reduce congestion and VMT and consider land use changes (especially decisions related to parking and to expanding the urban growth boundary) that can support active transportation (by placing uses closer together).

- Sustainability and the environment - Prioritize services and activities that reduce GHG emissions. As the City of Eugene updates its climate action plan, it should pay close attention to how new mobility and e-commerce are impacting VMT - specifically related to shared mobility and mode split. Policies should aim to reduce the total number of zero-occupancy vehicles on city streets. In addition, cities should consider how they allocate and manage the curb to ensure that the outcomes make it easy to walk, bike and take transit, and do not result in increased congestion or conflicts with preferred modes. Gresham should also consider how transportation services impact GHG emissions and transit use.

City staff and leaders should ensure that values - not technology - shape policies. In addition, they should adapt their fiscal policies to make sure that the policies support their goals and that they have the resources they need for implementation.

\subsubsection{Coordinate with regional partners}

Both Gresham and Eugene are part of larger regions - Gresham is a suburb to Portland and Eugene is the anchor city to a number of smaller bedroom communities. Gresham should look for opportunities to leverage what they want by working with the City of Portland, Metro, and other regional partners. It may be fiscally, legally, and politically easier to adopt or modify regulatory language from the City of Portland. In addition, the 
city should consider opportunities for data management and analysis by Portland, Metro, or other public agencies. If it hasn't already, the City of Eugene should initiate a conversation with regional partners to discuss the challenges and opportunities presented by new mobility and e-commerce services. It too should consider regional data analysis and policies that could help all jurisdictions prepare for the deployment of services.

\subsubsection{Develop a data privacy, management, and analysis plan}

As managers of the public right-of-way in which new mobility and urban delivery companies operate, public agencies need information about how the right-of-way is being used to understand how transportation services impact safety, health, GHG emissions, VMT, congestion, and other outcomes. More and more, public agencies are requiring information from transportation service providers to ensure that they understand the impacts of the service and to conduct short- and long-term planning to manage the transportation system as well as plan for transportation investments.

Public agencies have always collected transportation data, but the possibility of new data sources, either from data aggregators like Sidewalk Labs or other companies, or the transportation service providers themselves, means that local governments may have access to much more data, with the potential to get real-time data, that they haven't had before. The League of Oregon Cities articulated a number of reasons why cities need information about AVs and this is relevant to new mobility in general:

"The transportation system is changing more rapidly than ever before, so we need more up-to-date information ...We can't keep up with the pace of change unless we update the information we gather more frequently...Vehicles aren't sticking to highways, so we need more geographically detailed information...We need more detailed information on travel patterns, collisions and near-misses to better design the transportation system to keep everyone moving and prevent traffic deaths." (Hesse, 2019, p 1-2).

While some companies are advocating for aggregating data, aggregated data can only answer a limited number of questions. Cities will likely need trip-level data to ensure that companies comply with the requirements in their permits, such as limits on the total number of vehicles, placement of vehicles, parking information, fee payment, and more, information is needed from the companies to ensure compliance.

In order to analyze this data, cities and other public agencies will need to do two things at a minimum; (1) ensure they have the technical expertise to analyze the data, which has staffing implications, and (2) make sure they have privacy policies in place and a process that ensures that individual privacy can be protected. The City of Hillsboro adopted data privacy principles in December 2018 to guide its use of personal information. The City of Portland adopted privacy principles in June 2019 (Smart City PDX, 2019). 


\subsubsection{Track new mobility and e-commerce policies, programs, and research in larger cities and regions across the U.S.}

The larger cities and metros are leading the way in developing new policies around shared mobility and emerging technology. It may be prudent for both Gresham and Eugene to look at the examples from these cities, especially related to micromobility and TNCs, but wait to adopt policies specifically for AVs as the technology is still being tested and it remains to be seen exactly how it will be deployed and the impact it will have on cities. New mobility guidance is coming out on a weekly basis, including NACTO's Blueprint for Autonomous Urbanism 2.0 (2019c) and research from the University of Oregon, University of California, Davis, and the University of Washington, among many other academic, public and private organizations contributing to the evolution of thinking on new mobility topics in general and AVs in particular. The cities should consider adopting a strategy that clearly states goals and outcomes, but is flexible enough to adapt to the new mobility environment.

\subsubsection{Inform decision makers and residents about how emerging technologies are impacting cities}

New mobility services are changing how people and goods move. Some of these changes are obvious - people can see and ride e-scooters when they are deployed. Some of these changes are less visible - such as understanding just how much Amazon has increased the number of deliveries on city streets. While planning and transportation staff at most cities are aware that new mobility services are changing transportation dynamics, many elected and appointed officials, as well as the public, may be unaware of the scale of the potential impacts.

The Industrial Ecology and Growth Management students found that students, like much of the public, brought their own biases into their analysis and it was difficult for them to fully account for opportunity costs as well as the time value of money. It is difficult to compare transportation options if you are unfamiliar with some of the new transportation services. Change can be frightening and residents have real concerns with the safety of new technology as well as the potential economic impact.

Both cities should ensure that they have the information they need to understand (1) how emerging technologies are impacting cities; (2) how other communities are taking advantage of opportunities and addressing challenges; and (3) how the cities of Gresham and Eugene should approach these issues. City staff should consider how they will introduce these topics and how they will continue to keep elected officials and citizens informed over time.

\subsection{POLICY RECOMMENDATIONS}

If Gresham and Eugene decide to develop a new mobility strategy or update policies and plans as needed, they should consider specific changes on the following policy 
topics. While there is some overlap between the policies mentioned in the strategy section above, this section provides additional detail.

\subsubsection{Improve safety}

The City of Eugene has adopted Vision Zero policies and Gresham has adopted policies related to transportation safety. Both cities should ensure that new mobility services make their residents more safe, not less so. Both cities should carefully consider the safety record of new mobility providers, especially within some of the densest locations, such as in each city's downtown or large institutional or employment districts.

The Urban Design students focus on one of the densest areas of Gresham, and assumptions about a primarily autonomous vehicle future meant that they had a pedestrian-oriented focus that emphasized improving the safety of the studied areas. This may mean more aggressively protecting pedestrians and bicyclists by either restricting use of new mobility vehicles in certain areas (such as a state law that prohibits riding e-scooters on sidewalks) or building protected bike lanes to keep delivery vehicles and automobiles from obstructing bicyclists.

\subsubsection{Improve social equity}

The Industrial Ecology students found that high-income individuals benefit from new mobility services, but they become "cost prohibitive as families move below the area median income" (Cohen \& Skov, 2018, p 9).

The Navigating New Mobility report illustrated five areas where cities can focus to promote equitable outcomes from new mobility services (Urbanism Next Center, 2019):

- Provide a seat at the table. Include a diversity of people, including those who are directly impacted, in the process to develop policies and implementation regulations.

- Ensure that all areas are covered by the service. New mobility service providers often want to locate services and vehicles in the densest locations, often with a concentration of higher-income and higher-educated people. If Gresham and Eugene want to provide more transportation options to all residents, they will need to ensure that new services are available in all locations.

- Require diverse payment options. Cities can require new mobility providers to offer a low-income, reduced fare to improve affordability. In addition, some cities require fare options that allow people to pay without a smart phone or a credit card.

- Ensure that companies promote equitable workforce policies. Ensure that new mobility companies' workforces reflect the community they work in.

- Accommodate people with disabilities, youth, and seniors. Some new mobility service providers have recently provided additional options for people 
with disabilities, such as adaptive e-scooters that have seats and TNC options designed specifically for seniors or youth.

\subsubsection{Promote active transportation}

The findings from the Industrial Ecology class emphasized that active transportation modes were the least costly and most efficient way to move people in cities. The Land Use Planning \& Policy class report reminds us that policies don't work in isolation, but often take the adoption and implementation of multiple different strategies to achieve community goals. Virtually every class project and the Navigating New Mobility report emphasized the need to ensure that cities are and continue to be great places for people to walk, bike, and take transit, as well as for new mobility services. Specifically, the findings in these reports suggest that Gresham and Eugene should:

- Repurpose existing parking for other modes and uses. The Urban Design studio made assumptions about ridesharing, micromobility, and AVs that would likely reduce the demand for parking and increase the expectation that downtown populations will increase over time. This provides an excellent opportunity to transform areas to be more human-centered and pedestrian-oriented. In addition, they explored a variety of possibilities to activate space through increasing green spaces and plazas, as well as encouraging activities such as closing streets and designating them "play streets."

Student projects suggested limiting, reducing, eliminating or repurposing existing parking, specifically in areas where the City of Gresham wants to increase pedestrian use. They also suggested relocating parking to the periphery of downtown. By definition, new mobility modes reduce the dependence of residents owning their own vehicle and allow communities to repurpose space currently used for privately owned vehicles and use it for a more productive purpose. Those changes are a great opportunity for cities like Gresham and Eugene to increase the number of people who regularly walk, bike, or take public transit.

- Prioritize active transportation modes. Gresham and Eugene should prioritize pedestrian, bicycle, and transit infrastructure and programs including continuing existing efforts as well as expanding opportunities wherever possible.

- Build and protect pedestrian spaces. New mobility services and devices may encroach on sidewalks, walkways, trails, crosswalks, and other spaces. Cities should make sure that sidewalks are primarily for pedestrians. That could mean prohibiting e-scooters or other micromobility modes from sidewalks, as well as AV terrestrial drones, at least in the most congested spaces. Cities should also ensure new mobility vehicles don't park or operate in a way that would impede 
pedestrians.

- Build, expand, and protect bicycle facilities. New mobility services and devices may encroach upon bicycle facilities, from TNCs obstructing bike lanes when picking up or dropping off passengers to delivery vehicles obstructing bike lanes and e-scooters using bike lanes at faster speeds than the majority of cyclists. In addition, AV delivery vehicles are currently being designed to operate in bike lanes. Cities will need to determine how to reduce conflicts, especially those that result in serious crashes or fatalities, while protecting and promoting cycling. Expanding bicycle lanes may be beneficial to allow for passing, as well as more vehicles.

- Promote and expand transit facilities and use. One of the most efficient ways to move people in a city is by public transit. Nationally, there has been a reduction in transit use that is partially attributed to TNCs. Cities should continue to work closely with transit agencies and ensure that the policies that they adopt do not adversely affect transit ridership. Instead, new mobility services should support transit.

- Ensure that new mobility revenues can fund active transportation infrastructure and modes. Users who have the greatest impact on the transportation system should pay to mitigate that impact, especially if that impact increases congestion in cities. Cities should ensure that revenue generated can be used to improve the most efficient forms of transportation: walking, bicycling, and taking transit.

\subsubsection{Decrease greenhouse gas emissions and improve environmental quality}

Both Eugene and Gresham plans identify the need to reduce GHG emissions and improve quality. Urban Design students identified an additional opportunity to reduce stormwater runoff through stormwater planters, rain gardens and swales. Reducing parking and using planting also can create microclimates to reduce the urban heatisland effect. Pollution was not explicitly addressed in students' projects, though recommendations like improving walkability and promoting non-conventional vehicles will help to decrease GHG emissions and improve air quality.

Urbanism Next's research suggests that cities should pay attention to the potential impact of emerging technologies on GHG emissions (Urbanism Next Center, 2018). There are four areas that cities should pay attention to:

- Freight and goods movement. As e-commerce becomes a larger share of retail sales and goods delivery becomes more popular, cities may want to work on programs and strategies that encourage efficiency, such as combined deliveries, 
or charge a road usage charge, parking, or curb charge that reflects the cost to access the right-of-way and/or to manage demand.

- Vehicle miles traveled. Two ways that cities are looking to reduce VMT from new mobility services is to encourage the use of shared vehicles over zero- or single-occupancy vehicles and to encourage low-carbon travel such as walking, biking, and taking transit.

- Land use/metropolitan footprint. Cities should consider how new mobility options could result in increased VMT if people choose to live or work across long distances instead of in close proximity. Land uses that locate housing close to employment, shopping, entertainment, education, and other uses will be important to reducing GHG emissions from new mobility services in the future.

- Source of energy. One of the promises of many new mobility technologies is that they are likely to be electric in the future. Electric vehicles produce far fewer GHG emissions than conventional gasoline-powered vehicles.

\subsubsection{Reduce vehicle miles traveled and congestion}

As mentioned in the previous section, one of the primary ways for new mobility services to reduce VMT and congestion is to reduce zero- and single-occupancy vehicles by encouraging (or possibly requiring) shared vehicles. Another important factor will be to ensure that new mobility modes support and do not erode the number of people walking, biking, and taking transit. TNCs offer sharing services in many cities, but it remains to be seen how sharing reduces overall VMT. As cities design regulations for these services, they should evaluate how those regulations will impact sharing and active transportation use.

\subsubsection{Adapt right-of-way design and management for new mobility services}

Cities control the right-of-way. City leaders will need to re-evaluate what can and cannot operate within the right-of-way and at what speed. Safety will likely dictate what vehicles are allowed and the speed of vehicles in each environment. Cities may need to determine what are the appropriate types of vehicles on sidewalks, recreational trails, bike lanes, roads, and highways. Should e-scooters be on recreational trails? Should $\mathrm{AV}$ terrestrial drones be on sidewalks. If so, what should the maximum speed of these vehicles be?

One way to address this issue is to prioritize modes like the City of Portland and the City of Victoria, B.C. (see Table 6-1).

Table 6-1: Prioritization of modes, Portland, OR, and Victoria, BC, 2019

\begin{tabular}{l|l|l}
\hline Priority & Portland, OR & Victoria, BC \\
\hline 1 & Walking & Pedestrians \\
\hline 2 & Biking & Cyclists \\
\hline 3 & Transit & Transit \\
\hline
\end{tabular}




\begin{tabular}{l|l|l}
\hline 4 & $\begin{array}{l}\text { Fleet automated vehicles that are electric and shared } \\
\text { (FAVES) }\end{array}$ & Commercial vehicles \\
\hline 5 & Other shared vehicles & Single occupancy vehicles \\
\hline 6 & $\begin{array}{l}\text { Low- or no-occupancy vehicles, fossil-fueled non-transit } \\
\text { vehicles }\end{array}$ & \\
\hline
\end{tabular}

Source: City of Portland, Portland 2035 Transportation System Plan (2018). City of Victoria, BC, Official Community Plan, Section 7: Transportation and Mobility, p 52.

A city that prioritizes walking and pedestrians has clear criteria for evaluating policies, regulations, and programming related to new mobility services. For example, the city that prioritizes walking will likely prohibit e-scooters from sidewalks, adopt regulations to ensure that e-scooter parking does not obstruct the sidewalk, and will limit the speed of AV drones, or even ban them in the most congested pedestrian locations or times. Cities should ensure that the services that use these facilities contribute revenue to pay for expansion, maintenance, and improvement.

Ultimately, cities should make sure that clearly articulated goals guide the adaptation of the right-of-way and management of new mobility services. Figure 6-1 shows how the right-of-way could be adapted to accommodate new mobility services. It envisions space on the sidewalk for pedestrians, as well as micromobility charging and parking. It also envisions a protected micromobility lane, drive lanes, and dedicated transit/microtransit lanes. ROW design is context sensitive and not all of these changes may be appropriate on all streets. In addition, on-street parking has been eliminated in anticipation of a significantly reduced demand for parking of personally owned vehicles. 
Figure 6-1: New mobility in the right-of-way

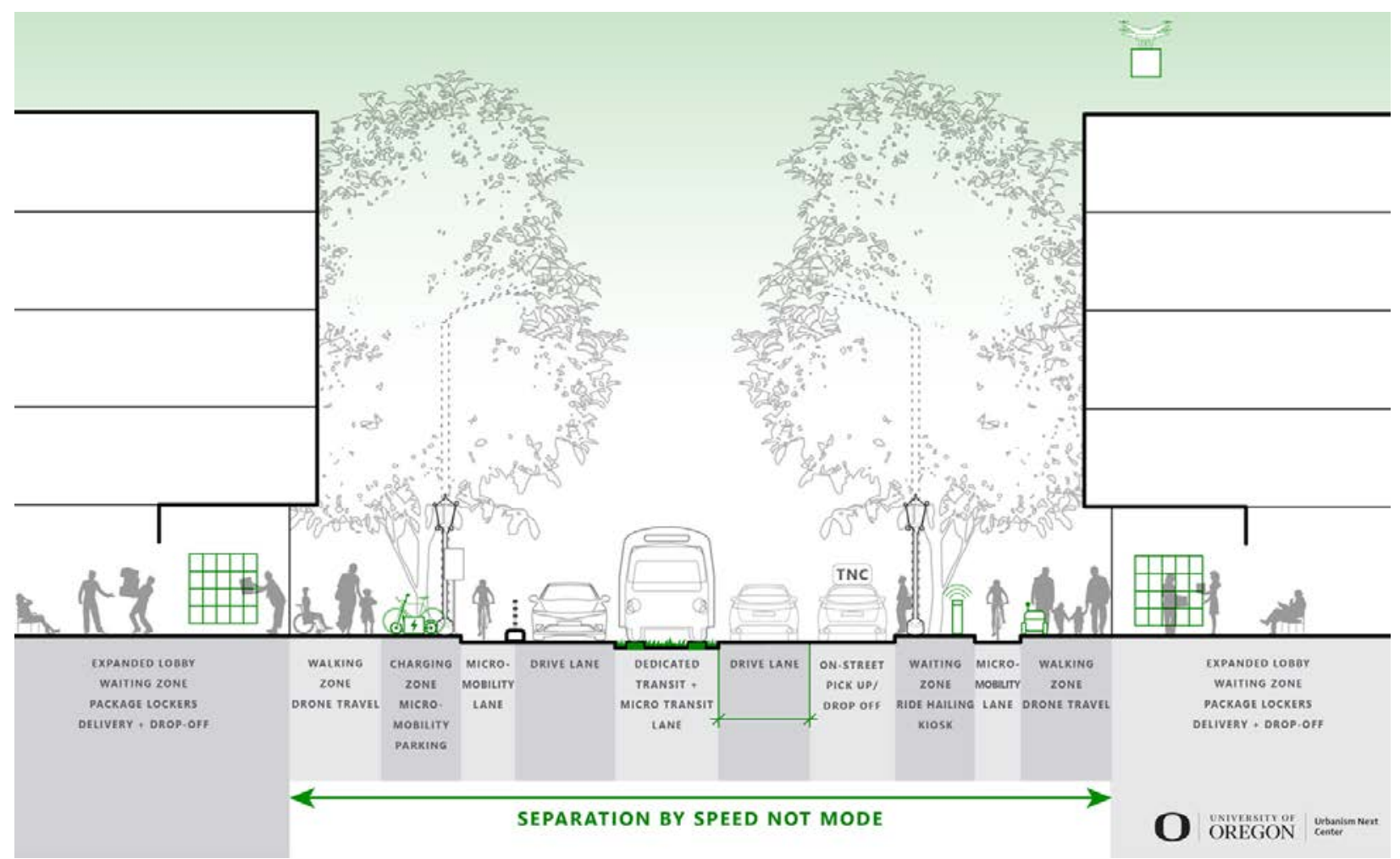

Source: Sabrina Ortiz and Marsie Surguine for Urbanism Next Center, 2019.

\subsubsection{Consider and manage changes in land use and metropolitan footprint}

The Public Budgeting class highlighted the potential of increased property tax revenues by encouraging the development of parking lots and suggested the adoption of a vacant land use tax to encourage this to happen. This is more likely to happen in areas of high demand for development - in downtowns and vibrant corridors and neighborhoods, as well as close to major employers.

Efforts to increase density have other potential benefits. The work from the Industrial Ecology students highlighted that the greatest household transportation savings are realized by using new mobility modes. They found "the closer a household to the city center - or the higher its walk, bike, or transit score - the more feasible adopting new mobility options became. The further one lives outside the city center, the less feasible new mobility becomes." (Cohen and Skov, p 10).

The Growth Management students noted that, unsurprisingly, currently adopted land use plans do not adequately address anticipated impacts of e-commerce or new mobility. Of the recommendations, we find the most promising related to the distribution 
and storage of goods. For example, as e-commerce continues to grow, distributers will look to be even closer to customers and may increasingly look to develop on-site package storage and locker facilities. Cities may see increased development in commercial, industrial and other land use zones related to the distribution and storage of e-commerce packages.

\subsubsection{Make informed decisions by requiring information}

The MPA Capstone students recommend that the cities of Gresham and Eugene use the standardized data requirements developed by the City of Los Angeles and consider privacy protections to protect individuals. There is a balance between a public agencies' desire for information and the desire to protect geolocation information of individuals. In fact, the Oregon AV Task Force made recommendations related to the differential privacy and opt-in options, as well as a "right to be forgotten" in its 2019 report to the Legislature (Task Force on Autonomous Vehicles, 2019). The City of Portland has joined forces with Austin, Chicago, Los Angeles, New York City, and many others to create the Open Mobility Foundation to support the development of software that can address data information challenges in cities.

\subsubsection{Manage innovation}

Public agencies are responding to new mobility technologies in innovative and novel ways. Some of the most common innovations are:

- Conducting pilot projects. Public agencies across North America are embracing short-term and limited vehicle pilot projects. Besides limiting vehicles and setting a time frame, the most successful pilot projects include an enforcement component, an outreach plan, data sharing, an evaluation, and revenues to fund the pilot. Public agencies should think about how they can incorporate what they learn into longer-term regulations.

- Public/private partnerships. Public agencies have a variety of ways to bring private services into a city. The most common is to conduct an RFP (request for proposals) and pay for a contract. However, cities are getting creative about how to work with the private sector, and a number of cities have conducted RFIs (request for information) to better understand the possible partnerships. Recognizing that the traditional procurement process is not designed for the rapidly evolving environment of new mobility, LA Metro created the unsolicited proposal process to consider public/private partnerships. To realize the potential of new mobility, Gresham and Eugene may want to consider how they can adapt in a quickly changing environment. 


\subsubsection{Consider fiscal impacts and opportunities}

The Public Budgeting students highlighted significant risk to both the cities of Gresham and Eugene's transportation revenue. While the SCYP report highlights one possible scenario, it shows an array of opportunities and ways of thinking about the fiscal challenge.

- Require fees to develop internal capacity to manage new mobility programs. The emergence of new mobility services is requiring transportation and other city departments from around the country to learn, create, and adapt processes, analyze new data, and integrate new mobility services into an existing transportation policy framework that is complex. More and more, cities are hiring or reassigning staff to address the issues that arise with the introduction of new mobility. Cities should be sure that they charge companies adequate fees to provide the city with the resources they will need to create the process, analyze data, and conduct enforcement.

- Collect a road usage charge (RUC) or vehicle miles traveled tax to pay for infrastructure. Given the work of the state road usage charge OreGo program, one of the first and most promising revenue options is to work with the State and implement a road usage charge/VMT charge. This will take close coordination with the State of Oregon, as well as Oregon's counties and cities, as all governmental entities that receive fuel taxes are potentially impacted by a transition to a RUC. While the OreGo program was designed to be revenue neutral — that is, it reimbursed individuals the difference if they paid more for the RUC than they would have in fuel taxes_cities, counties, and the State of Oregon may want to tie the charge directly to the capital costs of building and improving road infrastructure. Oregon clearly does not collect enough money to pay for the needed transportation infrastructure. This is an opportunity to rightsize revenue collection to better align with the actual need to pay for infrastructure.

Note that cities should consider charging a RUC for most or all vehicles that operate within the public right-of-way, whether that is a small autonomous vehicle riding on a sidewalk, e-scooters or autonomous trucks. There is a direct nexus between operation of the vehicle and resources necessary to build the infrastructure and maintain it as needed. All may use the public space, and all must pay to do so.

- Use pricing to manage congestion in districts, at the curb, and for special events. New mobility and smart phone technologies are rapidly evolving. The technology exists (or is in development) to allow cities to charge fees to use 
pricing to manage congestion. The opportunities that Gresham and Eugene are most likely to address are:

o Congestion pricing in downtown or other corridors or districts that experience regular congestion.

o Replacement of paid/unpaid parking for paid access to high-demand locations at the curb.

o Special events may also need special pricing and access management for un/loading close to the special event to encourage walking, biking, and transit use to the maximum amount feasible, and managing the total number of vehicles trying to un/load passengers at the event venue.

- Consider pricing tools to achieve equity, environmental, or other goals. Pricing can be used to signal preferred behavior. Many cities are adopting pricing schemes that discount low-income mobility programs or the use of low-carbon vehicles, for example. Cities should consider reducing the cost of desirable activities and increasing the cost of undesirable activities.

The student researchers also identified a number of other fees that help to reduce congestion by targeting zero-passenger vehicles (zombie) vehicles or single-occupancy vehicles.

- The importance of coordination with transit agencies and regional partners. Transportation choices impact multiple governmental entities. Coordination around pricing, especially for RUC and congestion pricing, will be important. While Metro (in the Portland region) and Lane Council of Governments (in the Eugene region) are natural partners for the regional discussion, each city will need to determine its respective strategy. In addition, it will be critical for Gresham to work with TriMet and Eugene to work with LTD to consider the potential impacts on transit use and planning. 


\subsection{REFERENCES}

Asenjo, Ian, Cameron Dively, Margaret Edwards, Zachary Ettensohn, Jeremy Goldstein, Gaurav Gupte, Alison Hoffman, and David Matvey. 2017. "Autonomous Vehicles and Transportation Equity in Pittsburgh." Carnegie Mellon University. https://www.cmu.edu/dietrich/ehpp/documents/EHPP2017Final.pdf.

Balding, Melissa, Teresa Whinery, Eleanor Leshner, and Eric Womerldorff. 2019. "Estimated TNC Share of VMT in Six US Metropolitan Regions (Revision 1)." Fehr and Peers. https://drive.google.com/file/d/1FIUskVkj9lsAnWJQ6kLhAhNoVLjfFdx3/view.

Bowman, Jeremy. 2017. "1 Year Later, Wal-Mart's Jet.Com Acquisition Is an Undeniable Success." The Motley Fool. October 3, 2017. https://www.fool.com/investing/2017/10/03/1-year-later-wal-marts-jetcomacquisition-is-an-un.aspx.

Brinklow, Adam. 2018. "City Blames Half of New Congestion on Lyft, Uber." Curbed SF. October 16, 2018. https://sf.curbed.com/2018/10/16/17984366/tnc-ride-hailinguber-lyft-sfcta-report.

Brown, Anne. 2018. "Ridehail Revolution: Ridehail Travel and Equity in Los Angeles." Dissertation. University of California Los Angeles.

Brown, Garrick. 2019. "The Great Retail Reinvention: Experience Matters." 1. Cushman \& Wakefield. http://www.cushmanwakefield.us/en/research-andinsight/2019/experiential-retail.

Cabanatuan, Michael. 2018. "SF Scooter Problem: City Impounds Dozens of the TwoWheelers - SFGate." SF Gate. April 13, 2018. https://www.sfgate.com/bayarea/article/SF-scooter-problem-City-impoundsdozens-of-the-12832354.php.

Cerasis. 2018. "The Top Logistics Trends That Will Impact Logistics Management in 2018." Cerasis. https://cerasis.com/wp-content/uploads/2018/02/The-TopLogistics-Trends-that-Will-Impact-Logistics-Management-in-2018.pdf.

Childress, Suzanne, Brice Nichols, Billy Charlton, and Stefan Coe. 2015. "Using an Activity-Based Model to Explore the Potential Impacts of Automated Vehicles." Transportation Research Record: Journal of the Transportation Research Board, no. 2493: 99-106.

City of Austin. n.d. "Austin Strategic Mobility Plan: Developing the Draft Policies." Accessed December 5, 2018.

https://austin.maps.arcgis.com/apps/Cascade/index.html?appid=66856e8c95244 e3b927253fd85878043.

City of Chandler. 2018. "ZCA18-0001 City of Chandler/Ride Sharing and Autonomous Vehicles Zoning Code Amendment." City of Chandler. https://www.chandleraz.gov/sites/default/files/documents/imported/ZCA180001.p df.

City of Portland, Bureau of Transportation. 2018. "Portland 2035 Transportation System Plan." City of Portland. https://www.portlandoregon.gov/transportation/67263.

Clewlow, Regina, and Gouri Mishra. 2017. "Disruptive Transportation: The Adoption, Utilization, and Impacts of Ride-Hailing in the United States." Institute of 
Transportation Studies, University of California, Davis.

https://steps.ucdavis.edu/new-research-ride-hailing-impacts-travel-behavior/.

Cohen, Rachel, and Joshua Skov. 2018. "New Mobility Case Study." Sustainable City Year Program. https://scholarsbank.uoregon.edu/xmlui/handle/1794/24648.

Colorado Department of Transportation, Denver Regional Council of Governments, Regional Transportatin District, and Denver Metro Chamber. 2018. "DRAFT Mobility Choice Blueprint." http://www.mobilitychoiceblueprintstudy.com/assets/resources/Mobility_Choice_ Blueprint_document_DRAFT_11.26.18.pdf.

Correia, Concalo, Dimitris Milakis, Bart van Arem, and Raymond Hoogendoorn. 2016. "Handbook on Transport and Urban Planning in the Developed World." Edward Elgar Publishing. https://doi.org/10.4337/9781783471393.

Crum, Carol, and Anne Brown. 2019. "Planning for a New Mobility Future." Sustainable City Year Program. https://scholarsbank.uoregon.edu/xmlui/handle/1794/24506.

Dalgadillo, Natalie. 2018. "Bird Says New Scooter Regulations Make It 'Impossible' to Serve D.C." Dcist. November 12, 2018. https://dcist.com/story/18/11/12/birdsays-new-scooter-regulations-make-it-impossible-to-serve-d-c/.

Davidson, Peter, and Anabelle Spinoulas. 2015. "Autonomous Vehicles: What Could This Mean for the Future of Transport." In Proceedings of the Australian Institute of Traffic Planning and Management (AITPM) National Conference, Brisbane, Australia. transposition.com.au/papers/AutonomousVehicles.pdf.

Department of Airports, Los Angeles, CA. 2017. "Los Angeles International Airport Annual Financial Report." Department of Airports, Los Angeles, CA. https://www.lawa.org/-/media/lawa-web/lawa-investorrelations/files/2017_lax_annual_report.ashx?la=en\&hash=302D0ECEE68148C6 B164ED70D40036814FA58271.

Ding, Ding, Klaus Gebel, Philayrath Phongsavan, Adrian E. Bauman, and Dafna Merom. 2014. "Driving: A Road to Unhealthy Lifestyles and Poor Health Outcomes." PLOS ONE 9 (6): e94602. https://doi.org/10.1371/journal.pone.0094602.

District Department of Transportation. 2018. "DDOT Releases New Permit Application for Dockless Vehicles." Government. District Department of Transportation. November 5, 2018. https://ddot.dc.gov/release/ddot-releases-new-permitapplication-dockless-vehicles\%C2\%A0.

Duffey, Stacie, Grace Park, Michael Thomas, and Benjamin Clark. 2019.

"Transportation Policy Options: New Mobility Services and Autonomous Vehicles." Sustainable City Year Program.

"Emerging Mobility." n.d. SFCTA. Accessed July 18, 2019. https://www.sfcta.org/policies/emerging-mobility.

Fagnant, Daniel J., and Kara M. Kockelman. 2014a. "The Travel and Environmental Implications of Shared Autonomous Vehicles, Using Agent-Based Model Scenarios." Transportation Research Part C: Emerging Technologies 40: 1-13. https://doi.org/10.1016/j.trc.2013.12.001. . 2014b. "The Travel and Environmental Implications of Shared Autonomous Vehicles, Using Agent-Based Model Scenarios." Transportation Research Part C: 
Emerging Technologies 40 (March): 1-13.

https://doi.org/10.1016/j.trc.2013.12.001.

Fehr \& Peers. 2018a. "How Will Autonomous Vehicles Influence the Future of Travel?" 2018. http://www.fehrandpeers.com/autonomous-vehicle-research/.

. 2018b. "San Francisco Curb Study." www.fehrandpeers.com/sf-curb-study/.

- 2019. "Cincinnati Curb Study." Clty of Cincinnati, Uber Technologies.

www.fehrandpeers.com/sf-curb-study/.

Gawron, James H., Gregory A. Keoleian, Robert D. De Kleine, Timothy J. Wallington, and Hyung Chul Kim. 2018. "Life Cycle Assessment of Connected and Automated Vehicles: Sensing and Computing Subsystem and Vehicle Level Effects." Environmental Science \& Technology 52 (5): 3249-56. https://doi.org/10.1021/acs.est.7b04576.

Gehrke, Steven R., Alison Felix, and Timothy Reardon. 2018. "Fare Choices Survey of Ride-Hailing Passengers in Metro Boston." Metropolitan Area Planning Council. https://www.mapc.org/farechoices/.

Gerdes, Justin. 2018. "Not So Fast. Fully Autonomous Vehicles Are More Than a Decade Away, Experts Say." February 6, 2018. https://www.greentechmedia.com/articles/read/fully-autonomous-vehiclesdecade-away-experts\#gs.9f5oja.

Goodyear, Sarah. No Date. "The Bike Share Boom." City Makers: Connections - How Urban Breakthroughs Spread and Evolve (blog). No Date. https://www.citylab.com/city-makers-connections/bike-share/.

Governing. 2018. "Special Report: How Autonomous Vehicles Could Constrain City Budgets." 2018. http://www.governing.com/gov-data/gov-how-autonomousvehicles-could-effect-city-budgets.html.

Graehler Jr., Michael, Richard Alexander Mucci, and Gregory D. Erhardt. 2019. "Understanding the Recent Transit Ridership Decline in Major U.S. Cities: Service Cuts or Emerging Modes?" In . Washington, DC. https://uknow.uky.edu/research/understanding-traffic-impacts-uber-lyft-gregerhardt.

Groshen, Erica L., Susan Helper, John Paul MacDuffie, and Charles Carson. 2018. "Preparing U.S. Workers and Employers for an Autonomous Future." Securing America's Future Energy. https://www.google.com/url?sa=t\&rct=j\&q=\&esrc=s\&source=web\&cd=1\&cad=rja \&uact=8\&ved=2ahUKEwjb9sbK7MHjAhVLwVQKHTyYBk8QFjAAegQIARAC\&url =https $\% 3 \mathrm{~A} \% 2 \mathrm{~F} \% 2 \mathrm{Favworkforce}$.secureenergy.org\%2Fwpcontent\%2Fuploads\%2F2018\%2F06\%2FGroshen-et-al-Report-June-20181.pdf\&usg=AOvVaw1-g4-p0dh7w3Rg-z3tkmc_.

Hand, Ashley Z., AIA, LEED AP BD+C. 2016. "Urban Mobility in a Digital Age: A Transportation Technology Strategy for Los Angeles." City of Los Angeles, Office of the Mayor and the Department of Transportation.

Harb, Mustapha, Yu Xiao, Giovanni Circella, Patricia L. Mokhtarian, and Joan L. Walker. 2018. "Projecting Travelers into a World of Self-Driving Vehicles: Estimating Travel Behavior Implications via a Naturalistic Experiment." Transportation 45 (6): 1671-85. https://doi.org/10.1007/s11116-018-9937-9. 
Hawkins, Andrew J. 2017. "Not All of Our Self-Driving Cars Will Be Electrically Powered - Here's Why." The Verge. December 12, 2017. https://www.theverge.com/2017/12/12/16748024/self-driving-electric-hybrid-evav-gm-ford.

Henao, Alejandro, Josh Sperling, Venu Garikapati, Yi Hou, and Stanley Young. 2018. "Airport Analyses Informing New Mobility Shifts: Opportunities to Adapt EnergyEfficient Mobility Services and Infrastructure." NREL/CP-5400-71036. CO: National Renewable Energy Laboratory. https://www.nrel.gov/docs/fy18osti/71036.pdf.

Hoagland, Emerson, RJ Theofield, and Yizou Yang. 2019. "Community Strategies for Improving Accessibility and Sustainable Transportation in Downtown Eugene." Sustainable City Year Program.

Humes, Edward. 2018. "Online Shopping Was Supposed to Keep People Out of Traffic. It Only Made Things Worse." Time. December 18, 2018. http://time.com/5481981/online-shopping-amazon-free-shipping-traffic-jams/. Kimmelman, Michael. 2012. "Paved, but Still Alive." The New York Times, January 6, 2012, sec. Art \& Design. https://www.nytimes.com/2012/01/08/arts/design/takingparking-lots-seriously-as-public-spaces.html.

Kludt, Amanda, and Daniel Geneen. 2018. "Inside the World's Fastest-Growing Food Delivery Service." Eater. 2018. https://www.eater.com/2018/6/29/17511590/ubereats-jason-droege-eater-upsell-podcast-listen.

Kohnke, Jennifer, and Rebecca Lewis. 2019. "Future-Proofing Comprehensive Plans in Eugene and Gresham." Sustainable City Year Program. https://scholarsbank.uoregon.edu/xmlui/handle/1794/24639.

Kolodny, Lora. 2019. "Elon Musk Claims Tesla Will Have 1 Million Robotaxis on Roads next Year, but Warns He's Missed the Mark before." CNBC. April 22, 2019. https://www.cnbc.com/2019/04/22/elon-musk-says-tesla-robotaxis-will-hit-themarket-next-year.html.

Korosec, Kirsten. 2019. "Waymo and Lyft Partner to Scale Self-Driving Robotaxi Service in Phoenix." TechCrunch (blog). May 7, 2019.

http://social.techcrunch.com/2019/05/07/waymo-and-lyft-partner-to-scale-selfdriving-robotaxi-service-in-phoenix/.

Krawiec, RJ, and Vinn White. 2017. "Governing the Future of Mobility." Deloitte Insights. 2017. https://www2.deloitte.com/insights/us/en/focus/future-of-mobility/federalgovernment-and-transportation-of-the-future.html.

LaMondia, Jeffrey J., Daniel J. Fagnant, Hongyang Qu, Jackson Barrett, and Kara Kockelman. 2016. "Long-Distance Travel Mode Shifts Due to Automated Vehicles: A Statewide Mode-Shift Simulation Experiment and Travel Survey Analysis." Transportation Research Board 95th Annual Meeting 11. https://doi.org/10.3141/2566-01.

Lipsman, Andrew. 2019. "Global Ecommerce 2019 US." June 27, 2019. https://www.emarketer.com/content/us-ecommerce-2019.

Litman, Todd. 2019. "Autonomous Vehicle Implementation Predictions: Implications for Transport Planning." Victoria Transport Policy Institute. https://www.vtpi.org/avip.pdf. 
Manville, Michael, Brian D. Taylor, and Evelyn Blumenberg. 2018. "Falling Transit Ridership: California and Southern California." UCLA Institute of Transportation Studies.

MaRS. 2016. "Microtransit: An Assessment of Potential to Drive Greenhouse Gas Reduction." https://www.marsdd.com/mars-library/microtransit-assessmentpotential-drive-greenhouse-gas-reductions/.

McLaughlin, Ralph. 2017. "How Driverless Cars Could Drive Even Deeper Economic Inequality." Fast Company. 2017. https://www.fastcompany.com/40490471/howdriverless-cars-could-drive-even-deeper-economic-inequality.

Men, Calvin. 2018. "Bird Scooters Impounded by Santa Cruz, Following Cease and Desist Order - Santa Cruz Sentinel." Santa Cruz Sentinel. September 17, 2018. https://www.santacruzsentinel.com/2018/09/17/bird-scooters-impounded-bysanta-cruz-following-cease-and-desist-order/.

Metro. 2018. "2018 Regional Transportation Plan - Emerging Technology Strategy (Public Review Draft)." Metro. https://www.oregonmetro.gov/sites/default/files/2018/07/02/Metro-EmergingTech-Strategy-06-2018-Public-Review-Draft.pdf.

Morris, David. 2018. "Yes, Uber Really Is Killing The Parking Business." Fortune, February 24, 2018. http://fortune.com/2018/02/24/yes-uber-really-is-killing-theparking-business/.

NACTO. 2017. "Blueprint for Autonomous Urbanism." National Association of City Transportation Officials. https://nacto.org/wpcontent/uploads/2017/11/BAU_Mod1_raster-sm.pdf.

_ 2019a. "Shared Micromobility in the U.S.: 2018." National Association of City Transportation Officials. https://nacto.org/wpcontent/uploads/2019/04/NACTO_Shared-Micromobility-in-2018_Web.pdf. .2019b. "Shared Micromobility in the U.S.: 2018." National Association of City Transportation Officials. https://nacto.org/shared-micromobility-2018/. . 2019c. "Guidelines for Regulating Shared Micromobility (Version 2)." NACTO. https://nacto.org/wpcontent/uploads/2019/09/NACTO_Shared_Micromobility_Guidelines_Web.pdf. . 2019d. "Blueprint for Autonomous Urbanism 2.0." National Association of City Transportation Officials. https://nacto.org/publication/bau2/.

Nourinejad, Mehdi, Sina Bahrami, and Matthew J. Roorda. 2018. "Designing Parking Facilities for Autonomous Vehicles." Transportation Research Part B: Methodological 109 (February): 110-27. https://doi.org/10.1016/j.trb.2017.12.017.

Peters, Adele. 2018. "Here's How Much Space U.S. Cities Waste on Parking." Fast Company. July 17, 2018. https://www.fastcompany.com/90202222/heres-howmuch-space-u-s-cities-waste-on-parking.

Peterson, Hayley. 2019. "More than 8,000 Stores Are Closing in 2019 as the Retail Apocalypse Drags on - Here's the Full List." Business Insider. August 14, 2019. https://www.businessinsider.com/stores-closing-in-2019-list-2019-3.

"Planning for a New Mobility Future." 2019. https://scholarsbank.uoregon.edu/xmlui/handle/1794/24638. 
Portland Bureau of Transportation. 2019. "2018 E-Scooter Findings Report." Portland Bureau of Transportation. https://www.portlandoregon.gov/transportation/78431.

Requia, Weeberb J., Moataz Mohamed, Christopher D. Higgins, Altaf Arain, and Mark Ferguson. 2018. "How Clean Are Electric Vehicles? Evidence-Based Review of the Effects of Electric Mobility on Air Pollutants, Greenhouse Gas Emissions and Human Health." Atmospheric Environment 185 (July): 64-77. https://doi.org/10.1016/j.atmosenv.2018.04.040.

Ribe, Rob, and Tshewant Tamang. 2019. "Exploring New Mobility Street Design for a Suburban Downtown in Transition." Sustainable City Year Program. https://scholarsbank.uoregon.edu/xmlui/handle/1794/24506.

Richland, Jud, Jim Lee, and Erin Duggan Butto. 2016. "Steering Autonomous Vehicle Policy: The Role of Public Health." Altarum Institute. https://altarum.org/sites/default/files/uploaded-relatedfiles/Autonomous\%20Vehicles\%20Report_final031816.pdf.

San Francisco County Transportation Authority. 2017. "TNCs Today: A Profile of San Francisco Transportation Nework Company Activity." https://www.sfcta.org/projects/tncs-today.

San Francisco Municipal Transit Agency. 2017. "Guiding Principles for Emerging Mobility Services and Technologies." San Francisco: SFMTA.

Schaller, Bruce. 2017. "Empty Seats, Full Streets: Fixing Manhattan's Traffic Problem." Schaller Consulting. schallerconsult.com/rideservices/emptyseatsfullstreets. pdf. . 2018. "The New Automobility: Lyft, Uber, and the Future of American Cities." Schaller Consulting. http://www.schallerconsult.com/rideservices/automobility.htm.

Schlossberg, Marc, and William Riggs. 2018. "Rethinking the Street in an Era of Driverless Cars." https://cpb-use1.wpmucdn.com/blogs.uoregon.edu/dist/f/13615/files/2018/01/Rethinking_Stree ts_AVs_012618-27hcyr6.pdf.

Seattle Department of Transportation. 2017. "New Mobility Playbook." City of Seattle. Shaheen, Susan, Nelson Chan, Apaar Bansal, and Adam Cohen. 2015. "Shared Mobility: Definitions, Industry Developments, and Early Understanding." The Transportation Sustainability Research Center at University of California, Berkeley. http://innovativemobility.org/?project=shared-mobility-definitionsindustry-developments-and-early-understanding.

Shoup, Donald. 2011. The High Cost of Free Parking. Revised edition. Planners Press. - ed. 2018. Parking and the City. Routledge.

Sisson, Patrick. 2018a. "Scooter Startup Bird Plans to Fund Protected Bike Lanes." Curbed. August 2, 2018. https://www.curbed.com/2018/8/2/17641604/birdscooter-safety-bike-lane.

— 2018b. "Scooter City: How Santa Monica, the Birthplace of Dockless Electric Scooters, Is Shaping the Multibillion-Dollar Industry." News. Curbed. December 7, 2018. https://www.curbed.com/2018/12/7/18130247/santa-monica-uber-lyftbird-lime-scooter-bike-app.

Smart City PDX. 2019. "Data Privacy and Information Protection Principlesfor the City of Portland." June 19, 2019. https://static1.squarespace.com/static/5967c18bff7c50a0244ff42c/t/5d0aec44693 
9ce00011ec049/1560996933477/COP_PIP_handout_June19_2019.pdf\%20on\% 20September\%2020.

Smith, Aaron, and Monica Anderson. 2016. "Online Shopping and E-Commerce." The Pew Research Center. https://www. pewinternet.org/2016/12/19/online-shoppingand-e-commercel.

Stark, Michelle, and Rebecca Lewis. 2018. "Transportation Revenue in the Age of New Mobility." Sustainable City Year Program. https://scholarsbank.uoregon.edu/xmlui/bitstream/handle/1794/24510/NewMobilit yFINALDRAFT. pdf?sequence=1\&isAllowed=y.

Steele, Jeanette. 2018. "Ace Parking Says Uber, Lyft Have Cut Parking Business up to 50\% in Some Venues." San Diego Union-Tribune. February 22, 2018. https://www.sandiegouniontribune.com/business/growth-development/sd-fi-aceparking-uber-lyft-competition-20180222-story.html.

Talebpour, Alireza, and Hani S. Mahmassani. 2016. "Influence of Connected and Autonomous Vehicles on Traffic Flow Stability and Throughput." Transportation Research Part C: Emerging Technologies 71 (October): 143-63. https://doi.org/10.1016/j.trc.2016.07.007.

Task Force on Autonomous Vehicles. 2018. "2018 Final Report to the Oregon State Legislature House Bill 4063 Task Force." State of Oregon.

—. 2019. "2019 Final Report to the Oregon State Legislature." 2. https://www.oregon.gov/ODOT/GetInvolved/Documents/AV\%20Task\%20Force\%20Report\%202019\%20FINAL.pdf.

Theen, Andrew. 2019. "TriMet Wants You to Combine Your Bus or MAX Trip with Uber, Biketown." Oregonlive.Com. March 14, 2019. https://www.oregonlive.com/clackamascounty/2019/03/trimet-wants-you-tocombine-your-bus-or-max-trip-with-uber-biketown.html.

Truong, Long T., Chris De Gruyter, Graham Currie, and Alexa Delbosc. 2017. "Estimating the Trip Generation Impacts of Autonomous Vehicles on Car Travel in Victoria, Australia." Transportation 44 (6): 1279-92. https://doi.org/10.1007/s11116-017-9802-2.

Uber. No date. "Find Uber in Cities around the World." Company website. No date. https://www.uber.com/global/en/cities/.

Urbanism Next Center. 2018. "AVs in the Pacific Northwest: Reducing Greenhouse Gas Emissions in a Time of Automation." University of Oregon. https://static1.squarespace.com/static/59ea2e51e5dd5ba9f8646cdc/t/5baa85821 04c7bc590732964/1537901957320/AVs+in+Pacific+NW+Baseline+Report+Sep2 018+Final.pdf.

— 2019. "Navigating New Mobility: Policy Approaches for Cities." Urbanism Next Center at the University of Oregon.

US Census Bureau. 2019. "Quarterly Retail E-Commerce Sales, 1st Quarter 2019." US Census Bureau. https://www.census.gov/retail/mrts/www/data/pdf/ec_current.pdf.

US Department of Commerce, and US Census Bureau. 2019. "Quarterly Share of ECommerce Sales of Total US Retial Sales from 1st Quarter 2010 to 2nd Quarter 2019 (in Statista)." August 21, 2019. https://www.statista.com/statistics/187439/share-of-e-commerce-sales-in-totalus-retail-sales-in-2010/. 
World Economic Forum. 2018. "Reshaping Urban Mobility with Autonomous Vehicles: Lessons from the City of Boston." REF 140518. World Economic Forum. http://www3.weforum.org/docs/WEF_Reshaping_Urban_Mobility_with_Autonomo us_Vehicles_2018.pdf.

Zipkin, Amy. 2017. "Airports Are Losing Money as Ride-Hailing Services Grow - The New York Times." New York Times, December 11, 2017. https://www.nytimes.com/2017/12/11/business/airports-ride-hailing-services.html. 